\title{
Baccharis sect. Caulopterae (Asteraceae, Astereae) no Rio Grande do Sul, Brasil
}

\author{
Gustavo Heiden ${ }^{1}$, João Ricardo Vieira Iganci ${ }^{2}$ \& Leila Macias ${ }^{3}$
}

\section{RESUMO}

(Baccharis sect. Caulopterae (Asteraceae, Astereae) no Rio Grande do Sul, Brasil) Foi realizado um estudo sobre a diversidade taxonômica de Baccharis sect. Caulopterae DC. no estado do Rio Grande do Sul, Brasil. É apresentada a descrição morfológica com ênfase nas espécies ocorrentes na área de estudo. Três lectótipos são designados e sete novos sinônimos são reconhecidos. A ocorrêcia de 22 espécies foi confirmada, sendo que duas representam novas ocorrências. Chave e descrições morfológicas para o reconhecimento das espécies são fornecidas, adicionalmente são apresentados ilustrações, dados referentes à distribuição geográfica e observações ecológicas no Rio Grande do Sul, além de comentários sobre similaridades morfológicas e taxonômicas.

Palavras-chave: carqueja, Compositae, mata atlântica, pampa, taxonomia.

\section{Abstract}

(Baccharis sect. Caulopterae (Asteraceae, Astereae) in Rio Grande do Sul State, Brazil) A study of the taxonomic diversity of Baccharis sect. Caulopterae DC. in Rio Grande do Sul State, Brazil, is presented. Three lectotypes were chosen and seven new synonyms were proposed. Twenty two species within the section were recognized, two of them are new records to the state flora. Key and morphological descriptions of the species are presented. Additionally, illustrations and data concerning to geographic distribution and ecological observations of the species in Rio Grande do Sul are discussed, including comments about morphological and taxonomic similarities.

Key words: carqueja, Compositae, atlantic rain forest, pampa, taxonomy.

\section{INTRODUÇÃO}

Asteraceae é a maior família de plantas com flores, ocorrendo em todos os continentes, com exceção da Antártida. Compreende mais de 1.600 gêneros e 23.600 espécies (Jeffrey 2006; Panero \& Funk 2008), sendo especialmente bem representada em savanas e formações campestres, e comparativamente pouco expressiva em florestas tropicais úmidas de terras baixas (Jeffrey 2006). A proposta mais recente de classificação reconhece 12 subfamílias e 28 tribos, dentre as quais a tribo Astereae, que emerge como um grupo monofilético (Panero \& Funk 2008). Esta tribo ocorre amplamente nas regiões temperadas e tropicais do mundo, compreendendo cerca de 205 gêneros e 3.080 espécies (Nesom \& Robinson 2006), classificados em 18 subtribos, dentre estas a subtribo Baccharidinae Less.

Baccharidinae é exclusivamente americana, sendo constituída pelos gêneros Archibaccharis
Heering e Baccharis L. (Müller 2006a). Baccharis compreende cerca de 360 espécies (Nesom \& Robinson 2006) originalmente distribuídas exclusivamente nas Américas, desde o sul do Canadá (Fielding 2001) até o sul da América do Sul (Giuliano 2001). Neste continente é profusamente diversificado e ocupa uma variedade de ambientes onde constitui um importante elemento em numerosas formações vegetacionais (Giuliano 2001). Os Andes, desde a Colômbia até a região central do Chile e da Argentina, e as regiões montanhosas do sudeste do Brasil, Uruguai e leste do Paraguai, são os principais centros de diversidade (Müller 2006a). Aproximadamente 145 espécies são encontradas no Brasil (Oliveira et al. 2006), distribuídas em maior concentração de São Paulo até o Rio Grande do Sul (Barroso 1976).

Baccharis sect. Caulopterae corresponde aos Grupos Organensis e Trimera de Barroso 
(1976) e ao Grupo Baccharis genistelloides de Müller (2006a). A seção é exclusiva da América do Sul e compreende 35 espécies, das quais 30 ocorrem no Brasil. O número de espécies e táxons infra-específicos relacionados por diferentes autores para a seçãoé variável devido às diferentes circunscrições adotadas na delimitação da seção e dos táxons que a compõe.

Os dois principais centros de diversidade da seção são os Andes da Colômbia até a Argentina, e as montanhas e planaltos das Regiões Sul e Sudeste do Brasil. Um centro secundário é representado por áreas de baixa altitude da Bacia do Rio da Prata, cujas espécies características ocorrem na Argentina, Paraguai, Uruguai e extremo-sul do Brasil. No Rio Grande do Sul, Baccharis sect. Caulopterae ocorre em todas as regiões fisiográficas do estado. A encosta do nordeste do Rio Grande do Sul apresenta a maior diversidade de espécies para a seção, pois representa uma área de transição entre regiões fisiograficamente distintas, possuindo uma ampla diversidade de ambientes. $\mathrm{Na}$ área do território estadual, em torno do paralelo $30^{\circ} \mathrm{S}$, ocorre o contato entre as espécies com centro de distribuição em áreas de altitude das Regiões Sul e Sudeste do Brasil, com aquelas cujo centro de distribuição ocorre nas planícies da Argentina (Heiden et al. 2007).

Devido ao fato do Rio Grande do Sul caracterizar-se como uma área de transição entre contingentes florísticos temperados e tropicais distintos e com a finalidade de contribuir para o conhecimento florísticotaxonômico de Asteraceae no estado, o objetivo deste trabalho é descrever e fornecer chave de identificação, ilustrações, informações sobre distribuição geográfica e observações ecológicas, além de comentários sobre as afinidades taxonômicas das espécies de Baccharis sect. Caulopterae relacionadas para a área de estudo.

\section{Material e Métodos}

O presente estudo foi efetuado através de revisão bibliográfica, consultas ao acervo de herbários, observações de campo e expedições de coleta. A revisão bibliográfica abrangeu a consulta de obras publicadas entre 1753 e 2009, referentes a publicações dos últimos 256 anos. Foram estudadas coleções do acervo dos herbários indexados B, C, CEPEC, F, G, GUA, HAS, HB, HBG, HURG, IAC, ICN, K, M, MO, NY, P, PACA, PEL, R, RB, S, SMDB, SP, SPF, US e W (siglas conforme Holmgren et al. 1998) e não indexados CNPO (Embrapa Pecuária Sul, Bagé, RS), HASU (Herbarium Aloysio Sehnem, Unisinos, São Leopoldo, RS), HECT (Herbário da Embrapa Clima Temperado, Pelotas, RS) e HUCS (Herbário, Museu de Ciências Naturais, Universidade de Caxias do Sul, Caxias do Sul, RS). Tipos e fotografias de tipos foram consultados nos herbários visitados, através de solicitação de empréstimo ou de bancos de imagens disponibilizados na rede. As estruturas foram analisadas e ilustradas com auxílio de estereomicroscópio, acoplado com câmara clara. As medidas de largura e diâmetro foram tomadas com o auxílio de um paquímetro digital nas porções mais largas das estruturas. A terminologia adotada para a descrição morfológica dos táxons foi baseada em Müller (2006a). Dados de fenologia, distribuição geográfica, nomes populares e observações ecológicas foram obtidos através das informações contidas em etiquetas, citações na literatura e observações em campo.

Os dados de distribuição geográfica são apresentados através da subdivisão do Rio Grande do Sul em dez regiões fisiográficas (Alto Uruguai, Campanha, Campos de Cima da Serra, Depressão Central, Encosta do Nordeste, Encosta do Sudeste, Litoral, Missões, Planalto Médio e Serra do Sudeste), modificado a partir de Fortes (1956) pela união das regiões fisiográficas Encosta Inferior do Nordeste e Encosta Superior do Nordeste. Os dados utilizados para a elaboração dos mapas são oriundos dos estudos taxonômicos, sendo que os mesmos foram confeccionados com o auxílio do aplicativo DIVA-GIS 5.4.

Os táxons são apresentados em ordem alfabética. Quando espécies que não ocorrem 
no estado foram comparadas com táxons ocorrentes no estado, ou quando espécimes provenientes de fora do estado foram utilizados para complementar as descrições diagnósticas, os espécimes utilizados foram listados no item material adicional selecionado.

\section{Resultados e Discussão}

Baccharis sect. Caulopterae DC., Prodr. 5: 424. 1836. TIPO: Baccharis genistelloides (Lam.) Pers. (lectótipo, designado por Cuatrecasas 1967).

Arbustos ou subarbustos; dióicos; aparentemente glabros, indumento geralmente em tufos diminutos, semelhantes a pontos resinosos, formado por tricomas flagelados unisseriados, raro clavados ou em pedestal, além de tricomas bisseriados; raro conspicuamente desenvolvido, viloso ou híspido. Caule cilíndrico, estriado ou alado; alas ou estrias decorrentes no limbo foliar. Folhas alternas, desenvolvidas ou escamiformes, pecioladas ou sésseis. Racemos ou panículas de ramos espiciformes; ramos espiciformes secundários desenvolvidos ou reduzidos a glomérulos e/ou capítulos solitários. Capítulos destituídos de páleas; clinanto glanduloso, densamente revestido por tricomas bisseriados glandulares. Capítulo masculino com invólucro campanulado ou cilíndrico. Flores masculinas tubulosas; corola actinomorfa, tubo cilíndrico, ápice 5-laciniado; estilete inteiro até 1/2-bífido, portando papilas de tamanho uniforme; rudimento de ovário estéril; papilho unisseriado. Capítulo feminino com invólucro campanulado ou cilíndrico. Flores femininas com corola filiforme, ápice da corola curtoligulado, provido ou destituído de 3-5dentículos, denticulado ou truncado, coroa subapical de tricomas ausente; estilete bífido, ramos lineares. Cipselas glabras, papilosas ou não; papilho unisseriado ou plurisseriado, não acrescente, cerdas espessadas na base e concrescidas.
Baccharis sect. Caulopterae é caracterizada principalmente pelo clinanto sem páleas e densamente revestido por tricomas glandulares, e pelas cerdas do papilho das flores femininas espessadas e concrescidas na base, formando um anel. A maior parte das espécies da seção possui caule estriado ou alado, sendo facilmente reconhecíveis através desta característica.

Várias espécies de Baccharis sect. Caulopterae são consideradas medicinais na sabedoria popular e conhecidas como carqueja. As carquejas de um modo geral são consumidas como infusão ou decocto, ou adicionadas no chimarrão. No uso interno são atribuídas funções como aperiente, antihelmíntica, anti-reumática, depurativa do sangue, emagrecedora, estomáquica, tônica para o fígado, e no tratamento de anemia, anorexia, cálculos biliares, colesterol alto, diabetes, diarréia, gastroenterites, gota, hipertensão, má circulação do sangue, reumatismo, gripe e resfriado, além de ação digestiva, diurética e tônica. No uso externo são utilizadas em lavagens para tratar feridas e ulcerações. Na indústria já foram utilizadas como substitutas do lúpulo na fabricação de cerveja, mas atualmente a maior importância econômica se deve a comercialização de ramos desidratados puros ou misturados a outras plantas medicinais na composição de produtos diuréticos e emagrecedores, adicionalmente, o lenho é referido como útil na limpeza dos dentes (Corrêa 1984; Simões et al. 1995; Heiden et al. 2006a). Com raras exceções, diferentes espécies são utilizadas indistintamente para as mesmas finalidades na medicina popular, entretanto, estudos científicos apontando eficácia, inocuidade ou contra-indicações são escassos. Algumas espécies possuem potencial de uso na floricultura de corte (Stumpf et al. 2008) e paisagismo, ocorrendo exploração extrativista e comercialização em mercados regionais. 


\section{Chave para a determinação dos táxons de Baccharis sect. Caulopterae no Rio Grande do Sul}

1. Caule e ramos estriados.

2. Ramos espiciformes (Fig. 1a)

21. B. vincifolia

2'. Panículas de ramos espiciformes (Fig. 1b).

3. Folhas com lâmina orbicular a oblonga, ápice arredondado

11. B. organensis

3'. Folhas com lâmina ovalada a lanceolada, ápice agudo a acuminado

12. B. paranensis

1'. Caule e ramos alados.

4. Ramos reprodutivos 2-alados (Fig. 1f-h).

5. Arbustos, raro subarbustos; xilopódio ausente; capítulos masculinos e femininos 3-5 mm compr.

5'. Subarbustos; xilopódio presente; capítulos masculinos 4-7 mm compr.; capítulos femininos 8-12 mm compr. 14. B. pentaptera

4'. Ramos reprodutivos 3-alados (Fig. 1e, g).

6. Subarbustos pilosos (Fig. 1j-k), destituídos de indumento em diminutos tufos.

7. Indumento viloso (Fig. 1k); lâmina foliar triangular a sagitada, raro ovalada .....

16. B. pseudovillosa

7'. Indumento híspido (Fig. 1j); lâmina foliar oblonga

17. B. ramboi

6'. Arbustos ou subarbustos, aparentemente glabros, indumento em diminutos tufos de tricomas (Fig. 1i).

8. Arbustos.

9. Folhas e/ou brácteas $>0,3 \mathrm{~cm}$ compr.

10. Folhas peninérveas

5. B. glaziovii

10'. Folhas uninérveas ou com 3 nervuras acródromas basais

11. Caule e ramos eretos; folhas com lâmina obovada ou elíptica $(0,5-$ $1,5 \times 0,2-0,6 \mathrm{~cm})$; uninérvea 1. B. apicifoliosa

11'. Caule e ramos flexuosos; folhas com lâmina oblanceolado-obovada ou elíptica $(0,5-6 \times 0,2-0,8 \mathrm{~cm}$ larg.); com 3 nervuras acródromas basais, parecendo uninérvea na face adaxial

4. B. flexuosiramosa

9'. Folhas e brácteas $\leq 0,3 \mathrm{~cm}$ compr.

12. Alas dos ramos vegetativos $\leq 0,4 \mathrm{~cm}$ larg.

13. Capítulos masculinos com invólucro globoso, flores 16-26; capítulos femininos com invólucro globoso, flores $25-60$, corola 1-1,2 mm compr.

8. B. microcephala

13'. Capítulos masculinos com invólucro campanulado, flores 22-40; capítulos femininos com invólucro cilíndrico ou campanulado, flores $80-115$, corola $1,5-2 \mathrm{~mm}$ compr. 13. B. penningtonnii

12'. Alas dos ramos vegetativos $\geq 0,5 \mathrm{~cm}$ larg.

14. Arbustos ereto-patentes ou escandentes; caule e ramos flexuosos; flores masculinas com corola 3,2-3,5 mm compr.; flores femininas com corola 3-3,5 mm compr.

6. B. jocheniana

14'. Arbustos eretos; caule e ramos eretos; flores masculinas com corola 2,3-2,8 mm compr.; flores femininas com corola 1,8-2,2 mm compr.

9. B. milleflora 
8'. Subarbustos.

15. Folhas $>1,5 \mathrm{~cm}$ compr.

16. Folhas com lâmina lanceolada a linear-lanceolada

15. B. phyteumoides

16'. Folhas com lâmina oblonga, ovalada ou triangular

7. B. junciformis

$15^{\prime}$. Folhas $\leq 1,5 \mathrm{~cm}$ compr.

17. Subarbustos 1-3 m alt.

18. Caule e ramos eretos ou ereto-patentes, folhas oblongo-sagitadas, $0,5-1,5 \mathrm{~cm}$ compr.

19. B. sagittalis

18'. Caule e ramos flexuosos, folhas escamiformes, $<0,5 \mathrm{~cm}$ compr.

19. Panículas 5-25 cm compr., raque com alas $1-1,5 \mathrm{~cm}$ larg., ramos espiciformes $1-14 \mathrm{~cm}$ compr.

6. B. jocheniana

19'. Panículas 25-70 cm compr., raque com alas 0,4-0,8 cm larg., ramos espiciformes $16-40 \mathrm{~cm}$ compr.

10. B. myriocephala

17'. Subarbustos $0,1-1 \mathrm{~m}$ alt.

20. Ramos espiciformes de capítulos solitários (Fig. 1d).

21. Subarbustos $0,1-0,25 \mathrm{~m}$ alt.; alas $0,01-0,13 \mathrm{~cm}$ larg., aplanadas nos ramos vegetativos; ramos espiciformes $0,5-4 \mathrm{~cm}$ compr. 22. Baccharis sp.

21 '. Subarbustos 0,25-0,65 m alt.; alas 0,25-0,75 cm larg., onduladas nos ramos vegetativos; ramos espiciformes $5-25 \mathrm{~cm}$ compr.... 18. B. riograndensis

20'. Ramos espiciformes de capítulos solitários e glomérulos com 2-8 capítulos Fig. 1c).

22. Folhas escamiformes, sésseis, triangulares 3. B. crispa

22'. Folhas desenvolvidas ou escamiformes, subsésseis, nunca triangulares

20. B. subtropicalis

1. Baccharis apicifoliosa A.A.Schneid. \& Boldrini, J. Bot. Res. Inst. Texas 2(1): 45. 2008. TIPO: BRASIL. RIO GRANDE DO SUL: São Francisco de Paula, 20.XI.2007, A.A. Schneider 1542 (holótipo ICN!; isótipos K, $\mathrm{MO})$.

Ilustração: Schneider \& Boldrini (2008).

Arbustos 0,75-1,5 m alt., eretos; aparentemente glabros, indumento em diminutos tufos de tricomas unisseriados e tricomas glandulares bisseriados. Caule e ramos eretos, verde-acinzentados, ramos vegetativos e reprodutivos 3-alados, alas $0,5-8 \times 0,1-0,6 \mathrm{~mm}$, aplanadas a onduladas. Folhas desenvolvidas ou escamiformes nos ramos vegetativos, subsésseis, lâmina 0,1-1 × 0,2-0,6 cm larg., obovada ou elíptica, base cuneada ou arredondada, ápice obtuso ou arredondado; uninérveas. Panículas piramidais, 5-12 cm compr., terminais; ramos espiciformes $1-5 \mathrm{~cm}$ compr., ramos espiciformes secundários reduzidos a capítulos solitários ou glomérulos com 2-3 capítulos; brácteas $(0,3)-0,5-0,8 \times 0,2-0,4 \mathrm{~cm}$, elípticas a obovadas. Capítulo masculino 3-
4,8 × 2,3-3,5 mm; invólucro cilíndrico; filárias 3-4 séries, externas ovaladas, medianas e internas elípticas a linear-elípticas, ápice curtamente fimbriado, margem escariosa. Flores masculinas 12-16; corola 2,8-3,3 mm compr., tubo 2-2,3 mm compr., fauce $0-0,2 \mathrm{~mm}$ compr., lacínias 0,8-1,2 mm compr.; pistilódio 3-3,5 mm compr., ápice inteiro; papilho 1,8-2,3 $\mathrm{mm}$ compr. Capítulo feminino 4,5-6,5 × 1,8-3 mm; invólucro cilíndrico; filárias 4-5 séries, externas ovaladas, medianas ovaladas a elípticas, internas linear-elípticas, ápice laciniado, margem escariosa. Flores femininas 20-28; corola 3,5-3,8 mm compr., curto-ligulada; estilete 4-5,3 mm compr. Cipselas 1-1,3 mm compr., cilíndricas, papilosas, 5-7 costadas; papilho 4-5,5 mm compr. Material selecionado: BRASIL. RIO GRANDEDO SUL: Hamburgerberg, 20.X.1892, fl., G.O.A. Malme 198 (R); Montenegro, 15.XI.1948, fl., A. Sehnem 3501 (RB); 26.X.1949, fl., fr., A. Sehnem 3961 (RB). Baccharis apicifoliosa ocorre no Sul (SC e RS) do Brasil. No Rio Grande do Sul éencontrada nos Campos de Cima da Serra e Encosta do Nordeste (Fig. 2). Vive em ambientes abertos 

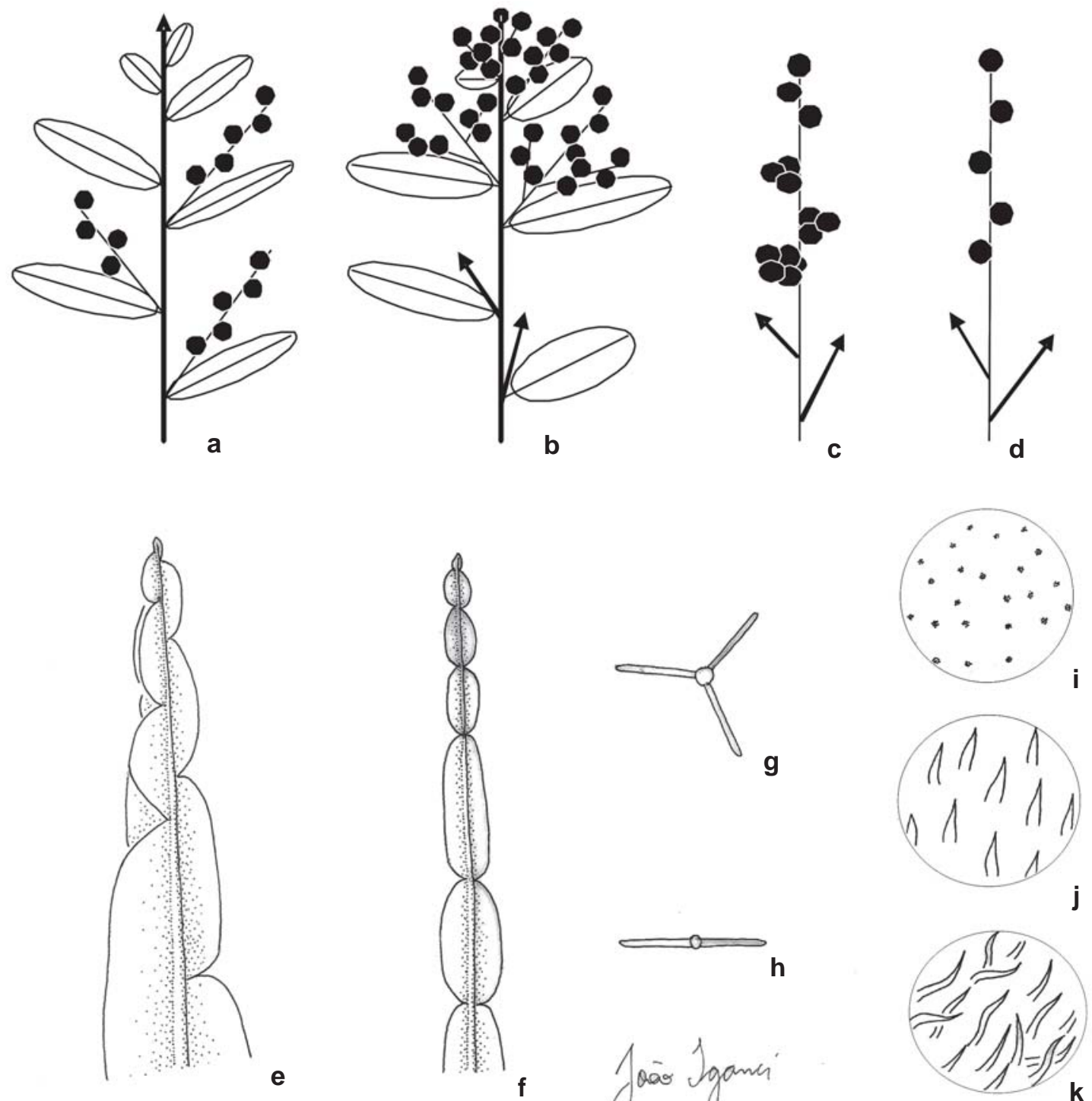

e

$\mathbf{f}$
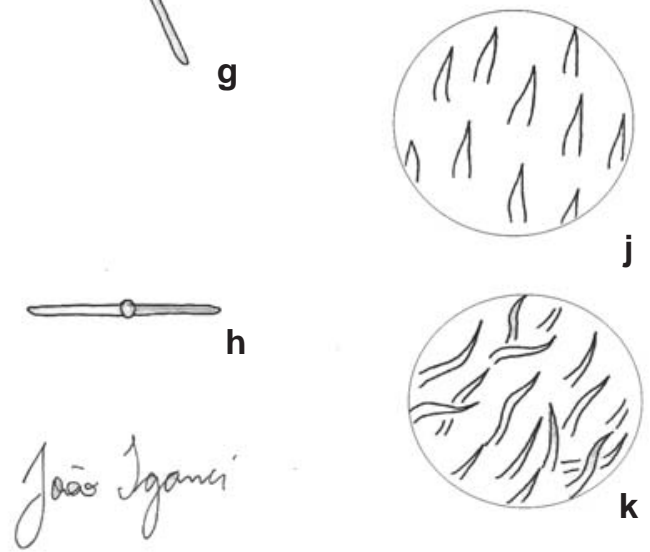

Figura 1 -a. ramos espiciformes; b. panículas de ramos espiciformes; c. ramos espiciformes de capítulos solitários e glomérulos; d. ramos espiciformes de capítulos solitários; e. caule 3-alado; f. caule 2-alado; g. caule 3-alado em seção transversal; h. caule 2-alado em seção transversal; i. indumento em diminutos tufos de tricomas; j. indumento híspido; $\mathrm{k}$. indumento viloso.

Figure 1 - a. spike-like branches; b. panicles of spike-like branches; c. spike-like branches of solitary capitula and glomerules; d. spike-like branches of solitary capitula; e. 3-winged stem; f. 2-winged stem; g. cross section of 3-winged stem; h. cross section of 2-winged stem; i. indumentum of small tufts; j. hispid indumentum; k. villous indumentum.

e ensolarados, tais como campos sujos e úmidos e beiras de estradas. Floresce de outubro a novembro.

Espécie próxima de $B$. milleflora, porém B. apicifoliosa diferencia-se pela presença de folhas elípticas a obovadas parcialmente desenvolvidas e pelos capítulos masculinos e femininos paucifloros. $\mathrm{O}$ exame de espécimes estudados por Malagarriga e Barroso demonstrou que os autores incluíram esta espécie em suas descrições de $B$. gaudichaudiana, $B$. glaziovii e $B$. milleflora. O epíteto se refere às brácteas folhosas no ápice dos ramos férteis. 
2. Baccharis articulata (Lam.) Pers., Syn. pl. 2: 425, 1807. Conyza articulata Lam., Encycl. 2: 94. 1786. Molina articulata (Lam.) Less., Linnaea 6: 140. 1831a. Pingraea articulata (Lam.) F.H.Hellwig, Candollea 48: 217. 1993. TIPO: URUGUAI. "Montevideo, dans le Paraguay," 우 o", Commerson s.n. (holótipo P-Lam, foto!, ơ ; isótipos B; HBGfragmento; $\mathrm{P}-3 \mathrm{x})$.

Fig. 3 a-f

Baccharis gaudichaudiana DC., Prodr. 5: 424. 1836. Baccharis articulata var. gaudichaudiana (DC.) Baker in Mart., Fl. bras. 6(3): 38. 1882. Baccharis articulata var. gaudichaudiana Loefgren, Bol. Commiss. Geogr. Estado São Paulo 10: 43. 1895. Baccharis articulata var. gaudichaudianum Chodat, Bull. Herb. Boissier 2(2): 383. 1902. TIPO: BRASIL. SANTA CATARINA: 1834, 우, Gaudichaud 198 (holótipo G-DC, foto!).

Ilustrações adicionais: Baker (1882); Cabrera (1963, 1974, 1978); Ariza (1973); Malagarriga (1977); Diesel (1987); Soria (1993); Müller (2006a).

Arbustos, raro subarbustos, xilopódio ausente; $0,5-2,5 \mathrm{~m}$ alt, eretos, resinosos, indumento em diminutos tufos de tricomas flagelados unisseriados e tricomas bisseriados glandulares. Caule e ramos eretos, verdeclaros ou verde-acinzentados, ramos vegetativos 2-3-alados, ramos reprodutivos 2alados; alas 0,3-7 ×0,3-0,6 cm, aplanadas, acentuadamente resinosas, aparentemente glabras. Folhas escamiformes, sésseis ou subsésseis, $1-2 \times 1-2,5 \mathrm{~mm}$, obtusas. Panículas piramidais de ramos espiciformes congestos, 0,5-5,5 cm compr., com 1-5 capítulos. Capítulo masculino 3-5 × 2,5-4 $\mathrm{mm}$; invólucro campanulado; filárias 3-5 séries, externas ovaladas a elípticas, medianas elípticas, internas oblongas, margem largamente escariosa, denticulada. Flores masculinas 18-30; corola 2,5-3,5 mm compr., tubo $1-1,5 \mathrm{~mm}$ compr., fauce $0,5-1 \mathrm{~mm}$ compr., lacínias 0,5-1,2 mm compr.; pistilódio 3-3,5 mm compr.; papilho 2-3 $\mathrm{mm}$ compr. Capítulo feminino 3-5 ×2,5-4 mm; invólucro cilíndrico a campanulado; filárias 4-5 séries, externas ovaladas a elípticas, medianas elípticas, internas oblongas, margem largamente escariosa, denticulada. Flores femininas 33-52; corola 1,5-2,3 mm compr., truncada; estilete 2-3,5 mm compr. Cipselas $0,5-1 \mathrm{~mm}$ compr., oblongas, papilosas, 3-5 costadas; papilho 2,53,5 mm compr. Número cromossômico $n=9$ (Rozenblum et al. 1985).

Material selecionado: BRASIL. RIO GRANDE DO SUL: Arroio dos Ratos, 1.X.1975, fl., K. Hagelund 10445 (ICN). Bagé, 2.I.1989, fl., M.R. Ritter 434 (ICN). Bom Jesus, 8.I.1934, fl., J. Dutra 1480 (ICN). Capão do Leão, 4.XII.1992, fl., G. Heiden 199 (PEL). Marcelino Ramos, 8.X.1988, fl., J.A. Jarenkow 921 (PACA, PEL). Montenegro, 8.IX.1949, fl, A. Sehnem s.n. (PACA 27769). Pelotas, 9.VIII.1954, fl., J.C. Sacco 214 (PACA). Piratini, 19.XI.1989, fl, J.A. Jarenkow 1447 (PEL). Porto Alegre, 14.VIII.1979, fl., O. Bueno 1643 (HAS). São Francisco de Paula, 3.XII.2000, fl., R.A. Wasum 809 (PACA). São Lourenço do Sul, 11.XI.2003, fl., G. Heiden 373 (PEL). Sentinela do Sul, 5.VIII.1996, fl. e fr., J.A. Jarenkow 3163 (PEL). Viamão, 20.IX.1964, fl., G. Pabst 8249 (HB, PEL).

Baccharis articulata ocorre na Argentina, Bolívia, Regiões Sudeste (SP) e Sul (PR, SC e RS) do Brasil, Paraguai e Uruguai. No Rio Grande do Sul é encontrada no Alto Uruguai, Campanha, Campos de Cima da Serra, Depressão Central, Encosta do Sudeste, Encosta do Nordeste, Litoral, Missões, Planalto Médio e Serra do Sudeste (Fig. 2). Trata-se de uma espécie amplamente distribuída em formações

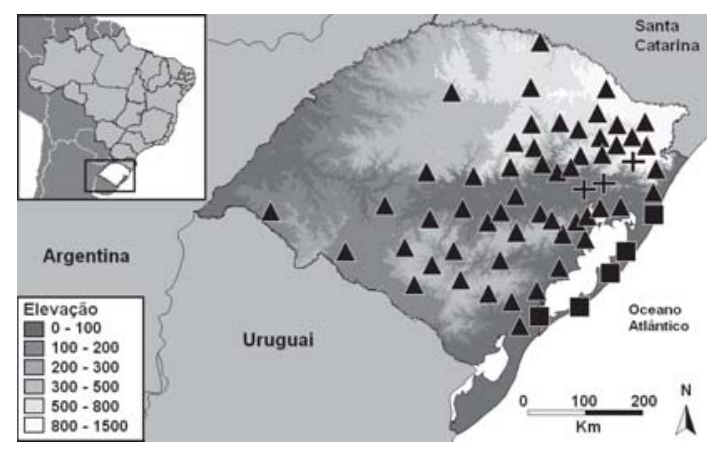

Figura 2 - Distribuição geográfica de Baccharis apicifoliosa A.A.Schneid. \& Boldrini (+), B. articulata (Lam.) Pers. (ム) e Baccharis sp. ( $\square$ ) no estado do Rio Grande do Sul.

Figure 2 - Geographic distribution of Baccharis apicifoliosa A.A.Schneid. \& Boldrini (+), B. articulata (Lam.) Pers. (A), and Baccharis sp. ( $\mathbf{\square})$ in Rio Grande do Sul, Brazil. 

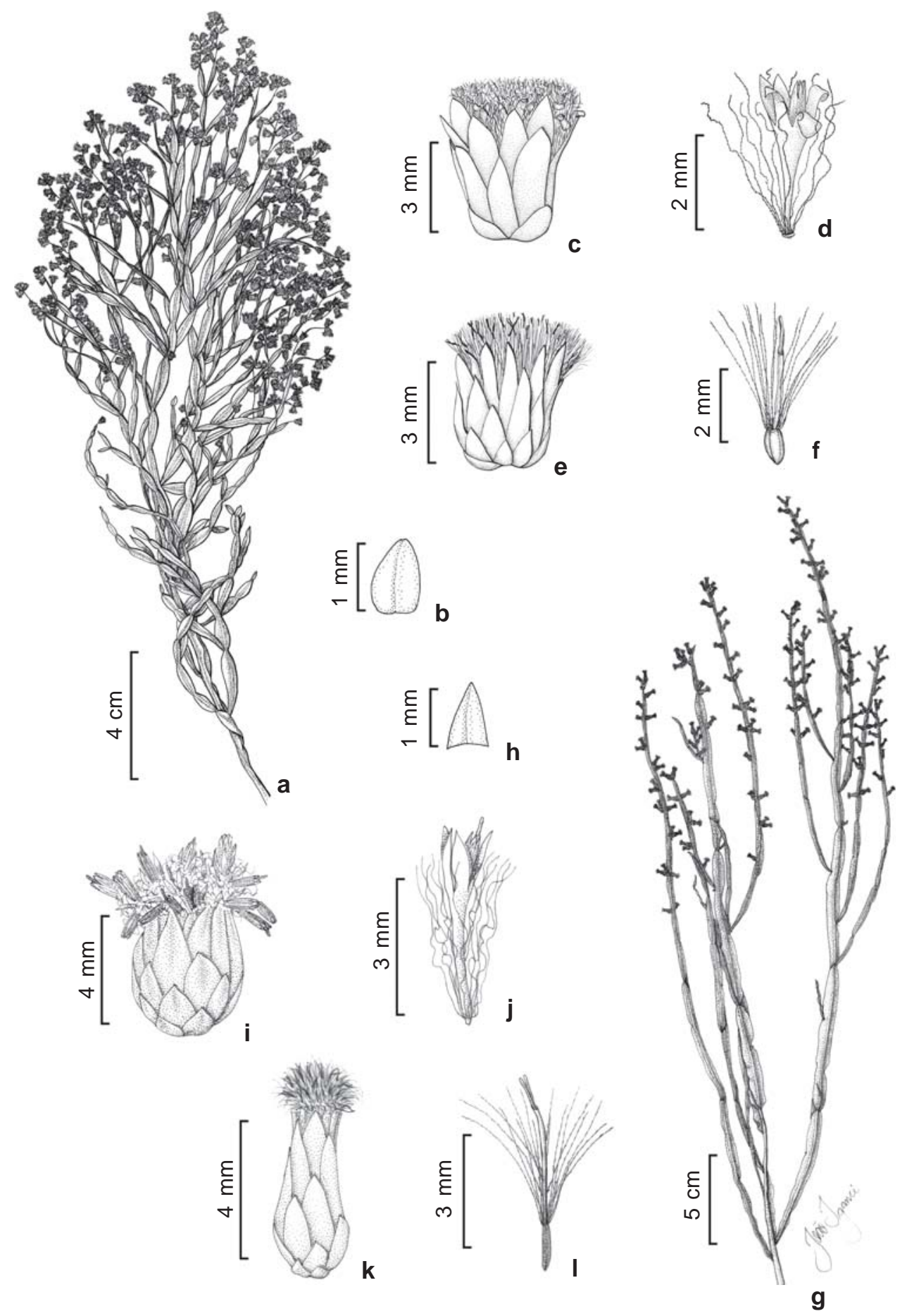

Figura 3 - Baccharis articulata (Lam.) Pers. - a. hábito; b. folha; c. capítulo masculino; d. flor masculina; e. capítulo feminino; f. flor feminina. Baccharis crispa Spreng. - g. hábito; h. folha; i. capítulo masculino; j. flor masculina; k. capítulo feminino; 1. flor feminina. (a-b, e-f Heiden 373; c-d Heiden 199; g-j Heiden 698; k-1 Heiden 699).

Figure 3 - Baccharis articulata (Lam.) Pers. - a. habit; b. leaf; c. male head; d. male floret; e. female head; f. female floret. Baccharis crispa Spreng. - g. habit; h. leaf; i. male head; j. male floret; k. female head; 1. female floret. (a-b, e-f Heiden 373; c-d Heiden 199; g-j Heiden 698; k-1 Heiden 699). 
campestres, que vegeta preferencialmente em terrenos secos e pedregosos onde pode formar populações extensas. Em outros ambientes, como bordas de mata ou margens de rios, ocorre esporadicamente. Ocasionalmente é encontrada em áreas ruderais e locais antropizados.

Embora seja amplamente utilizada na medicina popular, sendo alvo de extrativismo, a espécie não sofre exploração predatória, pois ocorre apenas a coleta de ramos vegetativos, normalmente sem causar a morte do indivíduo. Ocasionalmente é cultivada em hortas domésticas. Na medicina popular é preferida em relação às demais espécies de carqueja, pois é dita de sabor mais agradável, sendo utilizada também como aditivo ao chimarrão. Como floresce no fim do inverno é uma importante melífera e fonte de energia para visitantes florais durante esta época, quando há escassez de plantas férteis. O porte subarbustivo ou arbustivo, o aspecto cinza e os ramos bialados conferem potencial para o uso no paisagismo. Fértil ou não, presta-se ao corte sendo ocasionalmente utilizada como folhagem-de-corte ou complemento para a confecção de arranjos florais. Floresce de julho a outubro; a frutificação e a dispersão ocorrem logo após o florescimento, podendo se estender até dezembro. Popularmente é conhecida como carquejinha, carqueja-branca, carqueja-doce, carqueja-fina, carqueja-miúda e vassoura.

Espécie facilmente distinta, devido ao hábito geralmente arbustivo e ramos predominantemente bialados e cinzentos em indivíduos adultos. Discussão sobre a sinonimização de $B$. gaudichaudiana encontra-se em Schneider et al. (2009). O epíteto faz referência às alas caulinares constritas e curtas que conferem ao caule um aspecto articulado.

3. Baccharis crispa Spreng., Syst. veg. 3: 466. 1826. Molina crispa (Spreng.) Less., Linnaea 6: 141. 1831a. Baccharis genistelloides var. crispa (Spreng.) Baker in Mart., Fl. bras. 6(3): 41. 1882. Pingraea crispa (Spreng.) F.H. Hellwig, Candollea 46: 217. 1993. Baccharis genistelloides subsp. crispa (Sprengel) Joch. Müll., Syst. Bot. Monogr. 76: 198. 2006. TIPO: Uruguai, Montevideo, 1821/1822, o, F. Sellow d397 [M.I.B. 736] (holótipo P-218268, isótipos BR-818440; G-DC-2; P-218269, foto!; R!; W).

Fig. 3 g-1

Cacalia sessilis Vell., Fl. flum. icon. 8: tab. 73. 1831a. TIPO: tab. 73 in Vellozo, Fl. flum. icon. 8. 1831a (lectótipo, designado po Müller 2006a).

Molina cylindrica Less., Linnaea 6: 144. 1831a. Baccharis cylindrica (Less.) DC., Prodr. 5: 426. 1836. Baccharis genistelloides var. cylindrica (Less.) Baker in Mart., Fl. bras. 6(3): 41. 1882. TIPO: Uruguai, 1821/ 1822, ㅇ, Sellow $d 649$ (holótipo KW?; isótipos G-DC; P, foto!; W).

Molina trimera Less., Linnaea 6: 141. 1831a. Baccharis trimera (Less.) DC., Prodr. 5: 425. 1836. Baccharis genistelloides var. trimera (Less.) Baker in Mart., Fl. bras. 6(3): 40. 1882. TIPO: Brasil, Santa Catarina, Chamisso s.n.; Rio de Janeiro, Beyrich s.n. (síntipo KW?).

Ilustrações adicionais: Baker (1882), Cabrera (1963, 1974, 1978), Malagarriga (1977), Diesel (1987), Soria (1993).

Subarbustos $0,15-1 \mathrm{~m}$ alt., eretos; aparentemente glabros, indumento em diminutos tufos de tricomas clavados unisseriados e tricomas glandulares bisseriados. Caule e ramos eretos, ramos vegetativos e reprodutivos 3 -alados, alas $1-7 \times 0,3-1 \mathrm{~cm}$, aplanadas ou onduladas. Folhas escamiformes, sésseis, 1-4×1-2,5 mm, triangulares. Ramos espiciformes 3-20 $\mathrm{cm}$ compr., ramos espiciformes secundários reduzidos a capítulos solitários e glomérulos com 2-5 capítulos. Capítulo masculino 4-5,5 ×3-4 mm; invólucro campanulado; filárias 3-5 séries, externas ovaladas a oblongas, medianas elípticas a ovaladas, internas elípticas; margem curtamente a largamente escariosa. Flores masculinas 1835; corola 3-4,5 mm compr., tubo 2-2,5 $\mathrm{mm}$ compr., fauce $0,2-1 \mathrm{~mm}$ compr., lacínias 11,5 mm compr.; pistilódio 3,5-4,5 mm compr., ápice bífido, ramos divergentes; papilho 3-5 mm 
compr. Capítulo feminino 4-5,5 ×2,5-5 mm; invólucro cilíndrico a campanulado; filárias 4 5 séries, externas ovaladas a oblongas, medianas elípticas a ovaladas, internas elípticas, ápice denticulado, margem curtamente a largamente escariosa. Flores femininas 35-60; corola 34,5 mm compr., truncada; estilete 3,5-5,5 mm compr. Cipselas 1-1,5 mm compr., cilíndricas, papilosas, 8-12 costadas; papilho $2,5-5 \mathrm{~mm}$ compr. Número cromossômico $\mathrm{n}=9$ (Coleman 1968, Bowden 1945).

Material selecionado: BRASIL. RIO GRANDE DO SUL: Alegrete, 11.II.1990, fl., D. Falkenberg \& M. Sobral 5225 (ICN). Caxias do Sul, 12.II.2000, fl., A. Kegler 680 (HUCS). Cachoeira do Sul, 1.IV.1985, fl., M. Sobral 3801 (ICN). Encruzilhada do Sul, 30.I.1984, fl., M. Neves 381 (HAS). Pelotas, 15.III.1955, fl., J.C. Sacco 319 (PEL). Rio Grande, 29.IV.1981, fl., C. Pereira 55 (HURG). São Francisco de Paula, 13.III.1950, fl., B. Rambo s.n. (PACA46292). São José dos Ausentes, 18.III.2002, fl., R. Wasum et al. 1401 (HUCS). São Lourenço do Sul, 16.II.2003, fl., G. Heiden 314 (PEL); 1.III.2007, fl. G. Heiden 698, 699 (RB).

Baccharis crispa ocorre no Peru, Bolívia, Paraguai, Argentina, Uruguai (Müller 2006a) e nas Regiões Sudeste (MG, RJ, SP) e Sul (PR, SC e RS) do Brasil. No Rio Grande do Sul é encontrada no Alto Uruguai, Campanha, Campos de Cima da Serra, Depressão Central, Encosta do Sudeste, Encosta do Nordeste, Litoral, Missões, Planalto Médio e Serra do Sudeste (Fig. 4). Trata-se de uma espécie amplamente distribuída em formações campestres e áreas sob ação antrópica em todo o estado. Ocorre indiferentemente em terrenos secos ou úmidos, formando frequentemente populações densas e extensas. Trata-se da espécie de Baccharis sect. Caulopterae mais amplamente utilizada na medicina popular no Rio Grande do Sul. Embora seja alvo de extrativismo, não sofre exploração predatória, pois ocorre preferencialmente a coleta de ramos vegetativos, normalmente sem causar a morte do indivíduo. Ocasionalmente também é cultivada. Popularmente é conhecida como carqueja-amarga, carqueja-amargosa, carqueja-crespa, carqueja-de-folha-larga, carqueja-graúda e carqueja-grossa. Floresce predominantemente de dezembro a março, uma segunda floração de menor intensidade pode ocorrer em junho.

Sprengel (1826) descreveu B. crispa com base em Sellow d397, que embora conste na literatura como proveniente do Rio Grande do Sul, foi coletada no Uruguai. Lessing (1831a) ao propor a combinação Molina crispa, descreveu $M$. cylindrica, com base em Sellow d649, também do Uruguai; $M$. trimera, com base em coletas de Santa Catarina (Chamisso s.n.) e Rio de Janeiro (Beyrich s.n.); e $M$. milleflora, com base em coleta de Sellow sem número e de procedência desconhecida. De Candolle (1836) aceitou os táxons descritos por Lessing (1831a), entretanto restabeleu B. crispa e propôs as combinações novas $B$. cylindrica e B. trimera, e descreveu B. myriocephala. Posteriormente, Baker (1882) considerou $B$. crispa, B. cylindrica, B. myriocephala, $B$. trimera e $B$. milleflora (a qual sinonimizou $B$. myriocephala) como variedades da espécie andina $B$. genistelloides, e descreveu $B$. genistelloides var. brachystachys, sem listar material examinado. Conforme discutido por Malagarriga (1957), Baker (1882) baseou-se em exemplares de espécies distintas e equivocadamente identificadas para propor as novas combinações. Desta forma, as variedades propostas não foram consideradas em trabalhos subsequentes de Malagarriga (1954, 1957, 1958, 1977), Barroso (1976), Diesel (1987), Barroso \& Bueno (2002) e Heiden (2005). Estes autores consideraram B. crispa, $B$. cylindrica, B. myriocephala e $B$. trimera como espécies autonômas, entretanto caracteres de pouco valor taxonômico foram utilizados para distinguí-las, e algumas vezes estes nomes foram aplicados equivocadamente para designar espécimes pertencentes a outros táxons. Por outro lado, Ariza (1973), ao elaborar o tratamento florístico de Baccharis para a região central da Argentina incluiu $B$. cylindrica na sinonímia de $B$. crispa, posicionamento mantido por Giuliano (2000, 2001). No tratamento das espécies bolivianas de Baccharis, Müller (2006a: 32) propôs a combinação nova $B$. 
genistelloides subsp. crispa (Spreng.) Joch. Müll., sob a qual sinonimizou B. cylindrica, B. myriocephala e B. trimera. Oliveira et al. (2006) rejeitaram a combinação nova e as sinonimizações, indicando o restabelecimento destas espécies. No presente artigo, B. crispa e B. myriocephala são tratadas como táxons distintos ao nível de espécie. Por outro lado, com base na análise de tipos, fotografias de tipos, bibliografia e acervo das coleções dos herbários brasileiros, concorda-se com Müller (2006), quanto ao reconhecimento de $B$. cylindrica e $B$. trimera como sinônimos. $\mathrm{O}$ epíteto faz referência às alas onduladas dos ramos do holótipo.

4. Baccharis flexuosiramosa A.A.Schneid. \& Boldrini, J. Bot. Res. Inst. Texas 2(1): 45. 2008. TIPO: BRASIL. RIO GRANDE DO SUL: Cambará do Sul, 7.XII.2006, A.A. Schneider 1419 (holótipo ICN!; isótipos $\mathrm{K}, \mathrm{MO}$ ).

Ilustração: Schneider \& Boldrini (2008).

Arbustos 0,8-2,5 m alt., apoiantes ou escandente; aparentemente glabros, indumento em diminutos tufos de tricomas. Caule e ramos flexuosos, verde-acinzentados, ramos vegetativos e reprodutivos 3-alados, alas $0,5-6 \times 0,2-0,8 \mathrm{~cm}$ larg., aplanadas. Folhas desenvolvidas, sésseis ou com pecíolo até $4 \mathrm{~mm}$ compr., lâmina 1,2$3 \times 0,7-1,8 \mathrm{~cm}$, oblanceolado-obovada ou elíptica, base atenuada, ápice obtuso a arredondado; com 3 nervuras acródromas basais imperfeitas na face abaxial, parecendo 1-nérvea na face adaxial. Panículas piramidais, terminais; ramos espiciformes 1-3 cm compr.; brácteas foliáceas. Capítulo masculino 4-5 × 2-2,4 mm larg.; invólucro campanulado; filárias 3-4 séries, externas ovaladas, medianas elípticas, internas oblanceoladas ou lanceoladas, ápice fimbriado, margem estreitamente escariosa. Flores masculinas ca. 20; corola 3-3,5 mm compr., tubo 2-2,5 mm compr., fauce ca. 0,5 mm compr., lacínias ca. $1 \mathrm{~mm}$ compr.; pistilódio ca. 3,5 mm compr., ápice bífido, levemente intumescido, ramos coniventes; papilho 3-3,5 mm compr. Capítulo feminino 4,5-6×2-2,5 mm; invólucro cilíndrico; filárias 3-4 séries, externas ovaladas, medianas elípticas, internas linear-lanceoladas, ápice fimbriado, margem estreitamente escariosa. Flores femininas 20-25; corola 2,3-2,6 mm compr., ligulada, lígula 3-5-denticulada; estilete 3,1-4 mm compr. Cipselas 1,5-1,8 mm compr., cilíndricas, levemente comprimidas lateralmente, papilosas, 6-8 costadas; papilho 2,8-3,3 mm compr.

Material selecionado: BRASIL. RIO GRANDEDO SUL: Cambará do Sul, 7.XII.2006, A.A. Schneider 1420 (ICN, parátipo). São Francisco de Paula, 4.XII.2006, A.A. Schneider 1448 (ICN, parátipo). SANTA CATARINA: Urubici, 18.X.2006, A.A. Schneider 1348 (ICN, parátipo).

Baccharis flexuosiramosa ocorre na Região Sul (SC e RS) do Brasil. No Rio Grande do Sul é encontrada nos Campos de Cima da Serra e na Encosta do Nordeste (Fig. 4). A espécie vegeta em bordas de capões e matas e nas margens de rios em áreas sob influência da floresta ombrófila mista, em altitudes entre 900 e $1500 \mathrm{~m}$. Floresce entre outubro e dezembro.

Baccharis flexuosiramosa foi descrita por Schneider \& Boldrini (2008) que apontaram afinidades com B. organensis, diferenciandoa desta espécie com base nos ramos 3-alados e flexuosos e folhas aparentemente 1-nérveas na face adaxial. $\mathrm{O}$ epíteto faz referência aos ramos flexuosos.

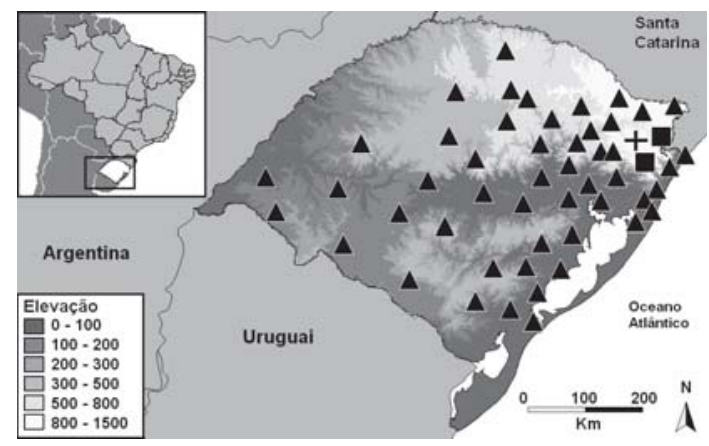

Figura 4 - Distribuição geográfica de Baccharis crispa Spreng. (A), B. flexuosiramosa A.A.Schneid. \& Boldrini (-) e B. glaziovii Baker (+) no estado do Rio Grande do Sul.

Figure 4 - Geographic distribution of Baccharis crispa Spreng. (山), B. flexuosiramosa A.A.Schneid. \& Boldrini (匹), and B. glaziovii Baker (+) in Rio Grande do Sul, Brazil. 
5. Baccharis glaziovii Baker in Mart., Fl. bras. 6(3): 44. 1836. TIPO:BRASIL. RIO DEJANEIRO: Itatiaia, A.F.M. Glaziou 5900 (lectótipo aqui designado: $\mathrm{K}$, foto!, isolectótipo P). Fig. 5 a-f Ilustração adicional: Malagarriga (1977).

Arbustos 0,5-2,5 $\mathrm{m}$ alt., eretos, apoiantes ou escandentes; aparentemente glabros, indumento em diminutos tufos de tricomas unisseriados e tricomas glandulares bisseriados. Caule e ramos eretos ou patentes, verdes, ramos vegetativos e reprodutivos 3-alados, alas 17-(19) $\times 0,4-1,3 \mathrm{~cm}$, aplanadas ou levemente onduladas. Folhas desenvolvidas, reduzindose ou não a escamas em direção ao ápice dos ramos, subsésseis; lâmina $(0,1)-0,5-6 \times(0,1)$ 0,5-2,7 cm, membranáceas, oblonga ou ovalada, base cuneada a arredondada, ápice obtuso a agudo, peninérveas. Panículas piramidais, 7-17 cm compr., axilares ou terminais; ramos espiciformes 1-4 cm compr., com 3-23 capítulos; brácteas foliáceas ou escamiformes. Capítulo masculino 4-5 × 3-4 mm larg.; invólucro oblongo ou campanulado; filárias 3-4 séries, externas e medianas ovaladas, internas linearelípticas, margem estreitamente escariosa. Flores masculinas 15-30; corola 2-2,4 mm compr., tubo 1,2-1,5 mm compr., fauce $0,3-$ 0,4 mm compr., lacínias $0,4-0,5 \mathrm{~mm}$ compr.; pistilódio 2-2,55 mm compr., ápice levemente bífido, ramos coniventes; papilho 2-2,2 $\mathrm{mm}$ compr. Capítulo feminino 5-6 × 2,5-3 mm; invólucro oblongo ou campanulado; filárias 4 séries, externas e medianas ovaladas, internas elípticas a linear-elípticas, ápice denteado, margem escariosa. Flores femininas 52-62; corola 2,2$3 \mathrm{~mm}$ compr., 3-5-denticulada; estilete 2,2-3 mm compr. Cipselas 0,8-1 mm compr., oblongas, glabras, papilosas, 5-6 costadas; papilho 3-3,5 mm compr.

Material examinado:BRASIL. RIOGRANDEDOSUL: Cambará do Sul, 20.X.1994, fl., M.R. Ritter 760 (ICN). Material adicional examinado: BRASIL. PARANÁ: Guarapuava, 18.X.1960, fl., G. Hatschbach 7386 (RB). São Mateus do Sul, 5.XI.2005, fl., G. Heiden 569 (RB). RIO DE JANEIRO: Itatiaia, A.F.M. Glaziou 4838 (síntipo K, foto!); 7.IX.1962, E. Pereira 7115 (PEL). SANTACATARINA: Campo Erê, 7.XII.1964, fl., L.B. Smith 13710 (RB). São José, 14.X.1960, fl.,
R. Reitz 10213 (RB). SÃO PAULO: Bananal, 7.X.1949, fl., A.C. Brade 20136 (RB). PARAGUAI. $\mathrm{km} 265$ da estrada Iguaçu-Asunción, 17.IX.1975, fl., P. McFadyen s.n. (RB 173966).

Baccharis glaziovii ocorre na Argentina, Paraguai e nas Regiões Sudeste (MG, RJ, SP) e Sul (PR, SC e RS) do Brasil. No Rio Grande do Sul ocorre nos Campos de Cima da Serra e na Encosta do Nordeste (Fig. 4). A espécie vegeta em campos, bordas de capões e matas, barrancos e beiras de estradas em áreas sob influência da floresta ombrófila mista. Observações em campo e registros de coleta para outros estados da Região Sul apontam o táxon como ocorrente em habitats primários e em áreas secundárias, entretanto é pouco representada em registros de herbário do Rio Grande do Sul. Floresce entre setembro e dezembro, frutificando em seguida.

Baccharis glaziovii possui dispersão ampla no sul do Brasil. A espécie não havia sido citada previamente para o Paraná e Santa Catarina por Barroso (1976), para o Rio Grande do Sul por Diesel (1987) e para Santa Catarina por Barroso \& Bueno (2002). Ao contrário do que indicam as referências bibliográficas, ocorre no Paraná, Santa Catarina e Rio Grande do Sul em regiões de altitude sob influência da floresta ombrófila mista. Populações do sudeste do Brasil possuem limbo foliar desenvolvido nos ramos vegetativos e reprodutivos, havendo uma tendência de redução em direção ao sul do país. Em observações de campo no sul do país, foi constatado limbo foliar desenvolvido em indivíduos jovens e estéreis, havendo redução com o desenvolvimento da planta. Em alguns exemplares o limbo foliar chega a reduzir-se em escamas nos ramos reprodutivos. A plasticidade morfológica resulta em problemas na identificação da espécie que frequentemente é determinada como $B$. gaudichaudiana, um sinônimo de B. articulata, ou como B. milleflora e B. phyteumoides.

Baker (1882) descreveu B. glaziovii com base em dois síntipos, ambos com capítulos imaturos. O espécime Glaziou 5900 é designado como lectótipo por apresentar capítulos mais desenvolvidos do que os encontrados no 

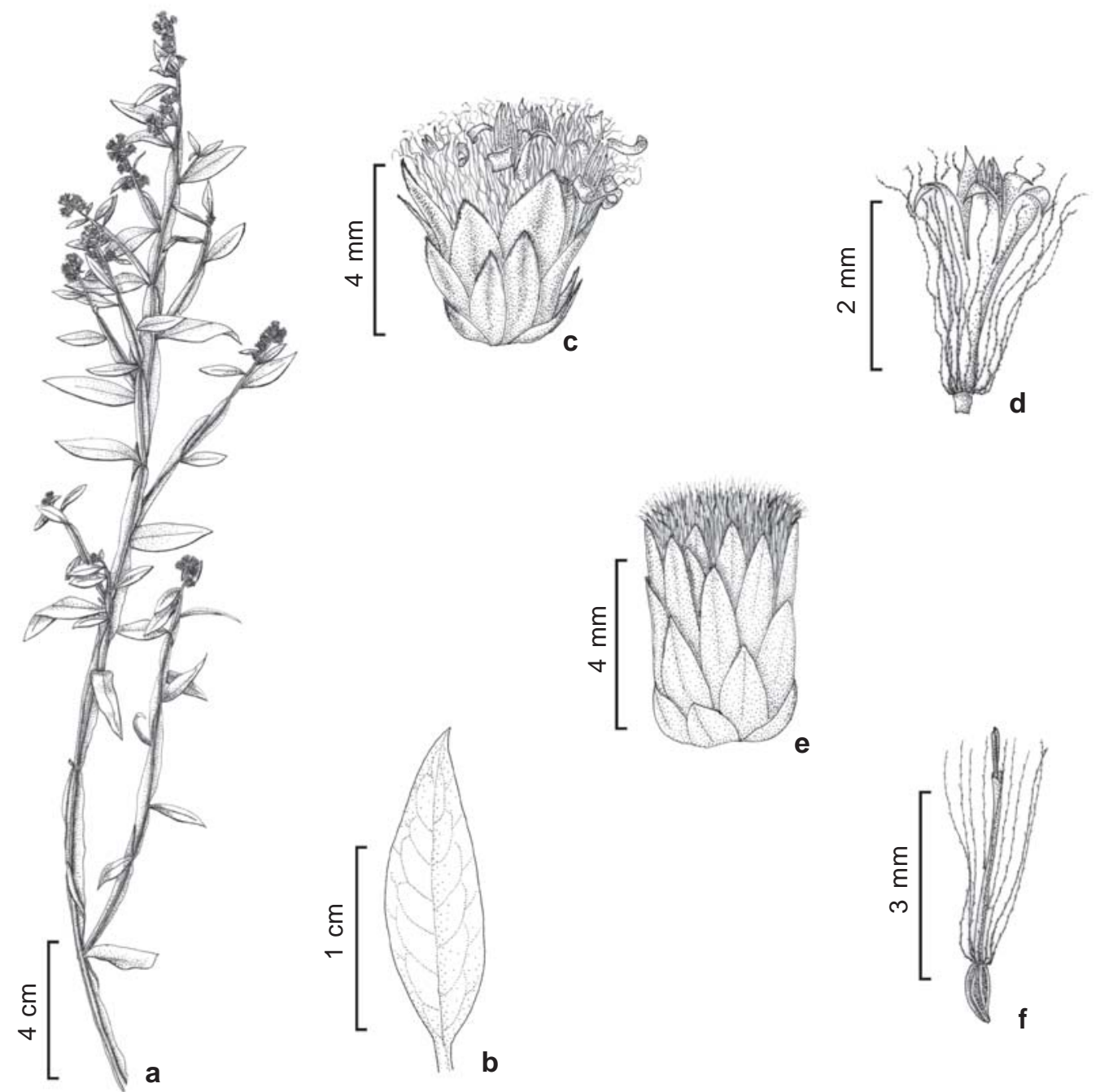

Figura 5 - Baccharis glaziovii Baker. - a. hábito; b. folha; c. capítulo masculino; d. flor masculina; e. capítulo feminino; f. flor feminina. (a-b, e-f Pereira 7115; c-d Heiden 569).

Figure 5 - Baccharis glaziovii Baker. - a. habit; b. leaf; c. male head; d. male floret; e. female head; f. female floret. (a-b, ef Pereira 7115; c-d Heiden 569).

exemplar Glaziou 4838. O epíteto homenageia Auguste François Marie Glaziou (1828-1926), coletor do tipo.

6. Baccharis jocheniana Heiden \& Macias, Novon 19(2): 178. 2008. TIPO: BRASIL. RIO GRANDE DO SUL: São Lourenço do Sul, Passo do Coqueiro, III.2006, ㅇ, G. Heiden 650 (holótipo PEL 24704!; isótipos HECT!; MO!). Ilustração: Heiden et al. (2008).

Arbustos ou subarbustos, 1-2,5 m alt., eretopatentes ou escandentes; indumento em diminutos tufos de tricomas clavados unisseriados e tricomas glandulares bisseriados. Caule e ramos flexuosos, ramos vegetativos e reprodutivos 3-alados, alas no caule principal e nos ramos secundários 1,5-10×1-2,5 cm larg., aplanadas a onduladas. Folhas escamiformes, sésseis, 0,05-0,1×0,1$0,2 \mathrm{~cm}$ larg., triangulares. Panículas $5-25 \mathrm{~cm}$ compr., congestas, raque com alas $1-1,5 \mathrm{~cm}$ larg.; ramos espiciformes $1-14 \mathrm{~cm}$, ramos espiciformes secundários reduzidos a glomérulos com 2-6 capítulos e capítulos solitários; brácteas escamiformes. Capítulo masculino 4,5-5 $\times$ 4-4,5 mm; invólucro oblongo a campanulado; filárias 4-6 séries, externas e medianas 
ovaladas, internas lineares, ápice agudo, margem escariosa, dentículada. Flores masculinas 35-40; corola 3,2-3,5 mm compr., tubo $2,5-3 \mathrm{~mm}$ compr., fauce $0,1-0,3 \mathrm{~mm}$ compr., lobos 0,5-0,8 mm compr.; pistilódio 3,2$4 \mathrm{~mm}$ compr., ápice inteiro; papilho 3-4 mm compr. Capítulo feminino 5,5-6×4,5-5 mm; invólucro oblongo; filárias 4-5 séries, externas oblongas, medianas elíptica, internas lineares, ápice agudo, margem escariosa, denticulada. Flores femininas 40-60, corola $3-3,5 \mathrm{~mm}$ compr., curto-ligulada, lígula 3-5-denticulada; estilete 3,5-4 mm compr. Cipselas 1,5-2 mm compr., oblongas, papilosas, 8-10 costadas; papilho 4,5-5 mm compr.

Material selecionado: BRASIL. RIO GRANDEDO SUL: Capão do Leão, 21.III.1950, fl., J. Gomes s.n. (PACA68809). Caxias do Sul, 19.III.2000, fl., A. Kegler 887 (HUCS). Jaquirana, 26.X.1986, fl., R. Wasum s.n. (HUCS). Pelotas, 8.III.1956, fl. e fr., J.C. Sacco 567, 568 (PEL, HB). Porto Alegre, 3.III.1950, f1., B. Rambo SJ s.n. (PACA 46051). São Francisco de Paula, 7.XI.1987, fl., G.G. Grazziotin s.n. (HUCS 3488); 8.X.2000, fl., R.A. Wasum 694 (PACA). São Lourenço do Sul, VI.2004, fl. e fr., G. Heiden s.n. (PEL 24700, RB); VIII.2005, fl., G. Heiden 386 (PEL 24701).

Baccharis jocheniana ocorre no Sul (RS) do Brasil, sendo registrada apenas no Rio Grande do Sul onde é encontrada na Depressão Central, Encosta do Sudeste, Encosta do Nordeste, Litoral e Serra do Sudeste (Fig. 6).

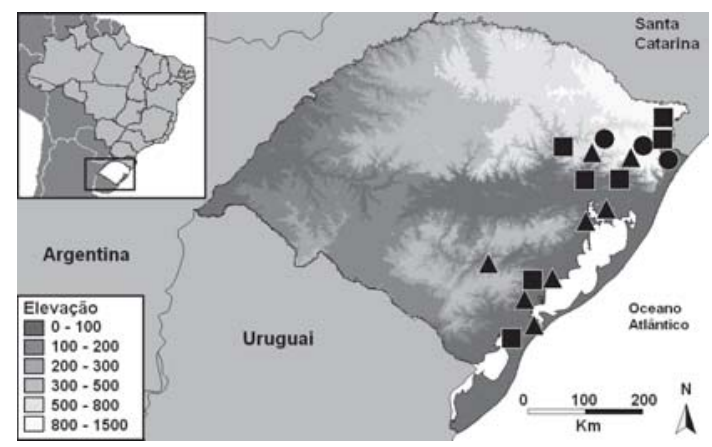

Figura 6 - Distribuição geográfica de Baccharis jocheniana Heiden \& Macias ( $\mathbf{\Delta})$, B. microcephala (Less.) DC. ( $\mathbf{\square})$ e B. milleflora (Less.) DC. ( $\bullet$ ) no estado do Rio Grande do Sul.

Figure 6 - Geographic distribution of Baccharis jocheniana Heiden \& Macias (A), B. microcephala (Less.) DC. ( $\mathbf{\square})$, and B. milleflora (Less.) DC. (•) in Rio Grande do Sul, Brazil.
Ocorre em bordas, clareiras, afloramentos rochosos ou cursos de água, vegetando como uma planta escandente. Indivíduos ereto-prostrados podem ocorrer esporadicamente em capões, barrancos e vertentes. Floresce a partir de março e a dispersão das cipselas ocorre até meados de setembro. Popularmente é conhecida como carquejão ou carqueja-de-folha-larga.

Baccharis jocheniana é comumente identificada como B. trimera (= B. crispa), devido ao caule 3 -alado, e é mais proximamente relacionada à $B$. myriocephala. Difere de $B$. crispa pelo hábito arbustivo e ereto-prostrado a escandente, ocorrência usualmente em ambientes sombreados ( $v s$. ocorrência restrita a locais sob sol pleno), alas do caule mais largas e flores femininas com ápice ligulado ou denticulado. Baccharis jocheniana se assemelha a B. myriocephala devido ao habitat preferencial e alas do caule principal largas. Entretanto, em $B$. jocheniana as panículas são formadas por ramos espiciformes congestos, o invólucro do capítulo feminino é mais largo, portando mais flores e flores femininas com corola curtoligulada com 3-5 dentículos, enquanto que em B. myriocephala os capítulos estão organizados em panículas de ramos espiciformes laxos, o invólucro do capítulo feminino é mais estreito, portando menos flores e flores femininas com corola truncada ou curto-ligulada, desprovidas de dentículos vestigiais. O epíteto homenageia o botânico alemão Jochen Müller, pesquisador especialista na subtribo Baccharidinae.

7. Baccharis junciformis DC., Prodr. 5: 426. 1836. Molina juncea Less. in Linnaea 6: 145. 1831b, non Baccharis juncea (Cass.) Desf., 1829. - TIPO: Brasilia australi, F. Sellow s.n. (holótipo não localizado; isótipo HBG s.n., foto!).

Fig. 7 a-f

Baccharis junciformis var. triptera Baker in Mart., Fl. bras. 6 (3): 43. 1882, non Baccharis triptera Mart., 1843. TIPO: Brasil, Minas Gerais, E. Warming 141 (holótipo C!). Syn. nov.

Baccharis usterii Heering in Usteri, Fl. São Paulo, p. 260. 1911. TIPO: Brasil, São Paulo, Santa Ana, locis humidis specimen unicum 

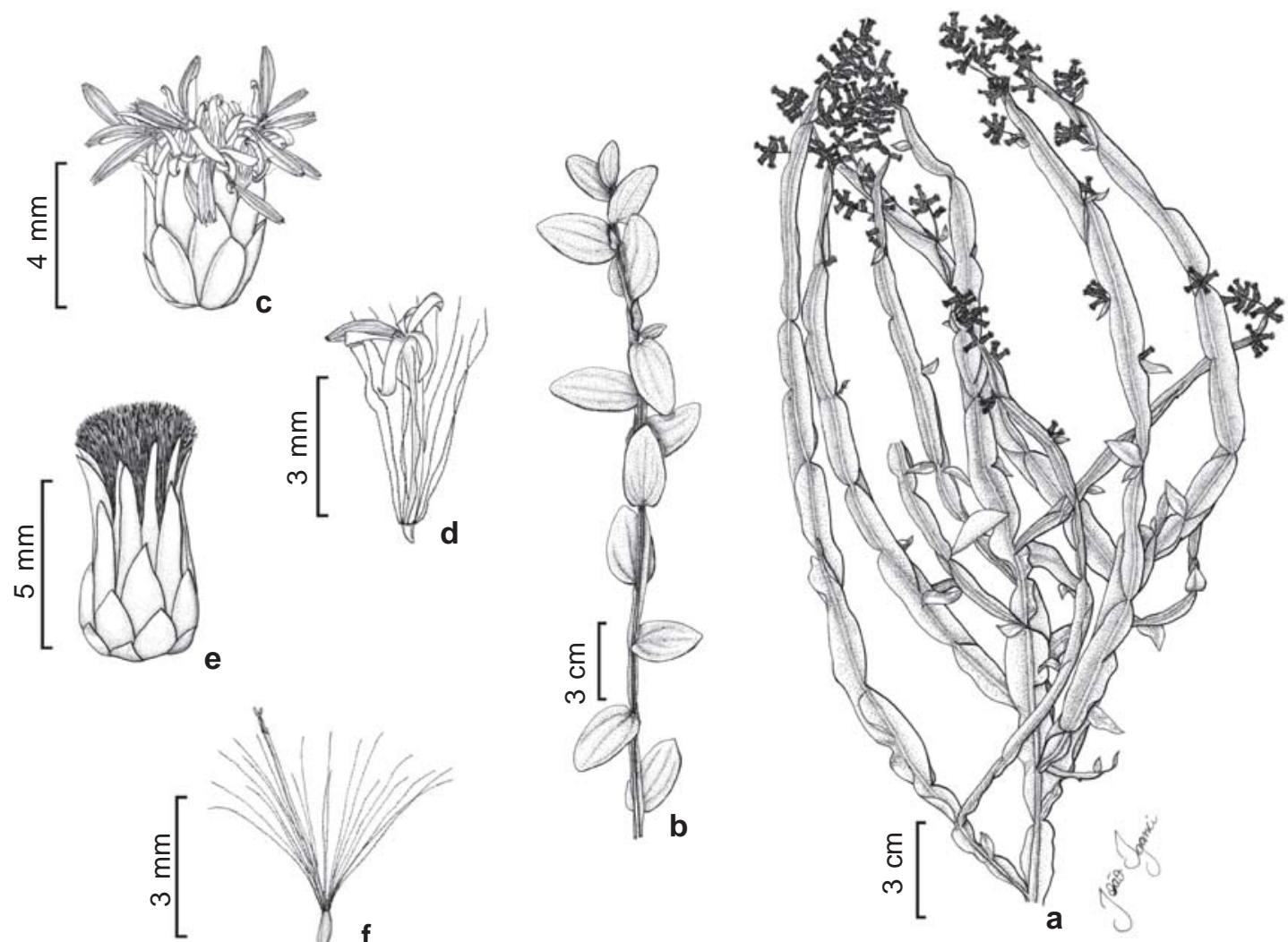

Figura 7 - Baccharis junciformis DC. a. hábito; b. ramo vegetativo basal; c. capítulo masculino; d. flor masculina; e. capítulo feminino; f. flor feminina. (a, e-f Heiden 374; b Heiden 679; c-d Dutra 1563).

Figure 7 - Baccharis junciformis DC. a. habit; b. basal vegetative branch; c. male head; d. male floret; e. female head; f. female floret. (a, e-f Heiden 374; b Heiden 679; c-d Dutra 1563).

inveni, 28.X.1906, A. Usteri s.n. (holótipo HBG 504946!; isótipo SP 16567!). Syn. nov.

Baccharis trimeroides Malme, Ark. Bot. 24A(6): 51. 1931. TIPO: Brasil, Rio Grande do Sul, Rio Grande, Quinta pr. Rio Grande oppid., 19 4/4 02 (II: 1605), G.O.A. Malme 1605 (holótipo S, foto!). Syn. nov.

Baccharis cordata Teodoro, Contr. Inst. Geobiol. 8: 37. 1957. TIPO: Brasil, São Paulo, Campinas, 26.V.1944, J. Theisen 7469 (holótipo IAC, foto!). Syn. nov.

Ilustração adicional: Malagarriga (1949a).

Subarbustos $0,5-1,5 \mathrm{~m}$ alt., eretos, aparentemente glabros, indumento em diminutos tufos de tricomas flagelados unisseriados e tricomas glandulares bisseriados. Caule e ramos eretos, ramos vegetativos e reprodutivos 3-alados, alas 3,5-8 $\times 0,5-1,5 \mathrm{~cm}$, aplanadas ou levemente onduladas, venulosas, ramos jovens com ápice avermelhado in vivo. Folhas desenvolvidas, subsésseis, lâmina 1,5-6×0,3$2 \mathrm{~cm}$, membranáceas ou cartáceas, oblonga, ovalada ou triangular, base cordada, ápice obtuso a agudo, margem revoluta; com 3 nervuras acródromas basais imperfeitas, secundariamente peninérveas. Panículas 8$30 \mathrm{~cm}$ compr., piramidais, ramos espiciformes 5-20 cm; brácteas foliáceas, triangulares ou sagitadas. Capítulo masculino 4-5,5×3-5 mm; invólucro cilíndrico a campanulado; filárias 45 séries, externas ovaladas, medianas ovaladas a elípticas, internas elípticas, margem estreitamente escariosa. Flores masculinas 20-33; corola 3,5-4,5 mm compr., tubo 3-4 mm compr., fauce 0-0,1 mm compr., lacínias 0,5-0,6 mm compr.; estilete 3,5-4,5 mm compr., ápice bífido, ramos lanceolados divergentes; papilho 3,5-4 mm compr. Capítulo feminino 5-6,5×3,5-5,5 mm; invólucro 
cilíndrico; filárias 5-7 séries, externas e medianas ovaladas, internas elípticas a lineares, margem inteira, estreitamente escariosa. Flores femininas 47-70; corola 3,4-5 mm compr., curto-ligulada ou truncada; estilete 4 4,3 mm compr. Cipselas 1-1,5 mm compr., ovaladas, não papilosas, 5-6 costadas; papilho 3,5-4 mm compr.

Material selecionado: BRASIL. RIO GRANDEDO SUL: Capão do Leão, 15.XII.2003, fl. e fr., G. Heiden 374 (PEL). Caxias do Sul, 11.I.1946, fl., B. Rambo s.n. (PACA 31190). Esmeralda, 2.IV.1978, fl., L. Arzivenco 4 (ICN). Montenegro, 6.V.1949, fl., B. Rambo s.n. (PACA 41432). Rio Grande, 12.V.1983, fl., M. Perazzolo 180 (HURG). Pelotas, 12.III.1958, fl., G.L. Brauner 12 (PEL). São Leopoldo, 23.IV.1937, fl., J. Dutra 1563 (PACA). São Lourenço do Sul, 26.XII.2006, G. Heiden 679 (RB). Torres, 10.VII.1972, B. Irgang \& A. M. Girardi-Deiro s.n. (ICN 28243). Vacaria, 6.I.1947, B. Rambo s.n. (PACA 34895).

Material adicional examinado: BRASIL. MINAS GERAIS: Hermílio Alves, 18.IV.1957, fl., E. Pereira \& G.Pabst 2936 (RB). RIO DE JANEIRO: Petrópolis, III.1944, fl., O.C. Góes \& Dionísio 362 (RB). SÃO PAULO: Santa Rita do Passa Quatro, 2.V.1948, fl., A.C. Brade 18918 (RB). PARANÁ: Matinhos, 8.III.2003, fl., J.M. Budel s.n.(ICN 127131). SANTA CATARINA: Caçador, 1956, fl., L. Smith \& R. Reitz 9079 (RB).

Baccharis junciformis ocorre nas Regiões Sudeste (ES, MG, RJ, SP) e Sul (PR, SC e RS) do Brasil. No Rio Grande do Sul é encontrada nos Campos de Cima da Serra, Depressão Central, Encosta do Sudeste, Encosta do Nordeste, Litoral e Serra do Sudeste (Fig. 8). Trata-se de uma espécie comum em banhados nas restingas e planícies do Litoral, assim como em áreas úmidas sob influência da Mata Atlântica nos contatos com os campos das Encostas do Nordeste e do Sudeste. Pode formar densas populações nas margens de arroios, banhados e em escoadouros de açudes e canais de irrigação agrícola, onde por vezes, dificulta o fluxo de água. Floresce de abril a junho com dispersão das cipselas até início de agosto. Popularmente é conhecida como carqueja-do-banhado.

Baccharis junciformis é uma espécie polimórfica, porém de fácil reconhecimento em campo devido ao hábito subarbustivo, caule

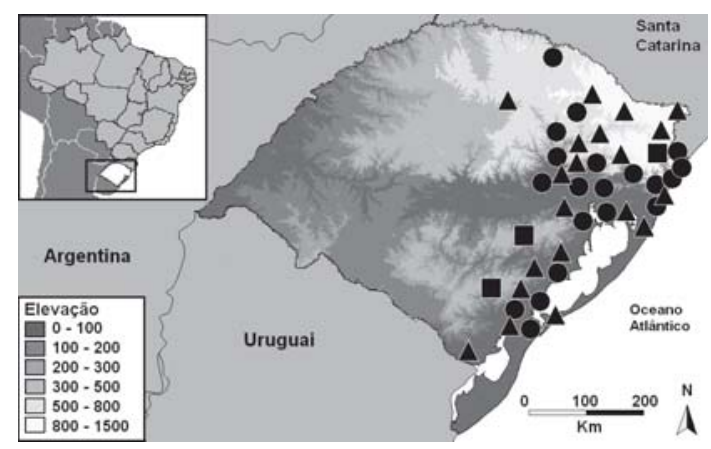

Figura 8-Distribuição geográfica de B. junciformis DC. $(\bullet)$, Baccharis subtropicalis Heiden $(\boldsymbol{\Delta})$ e B. vincifolia Baker. ( ) no estado do Rio Grande do Sul.

Figure 8 - Geographic distribution of Baccharis

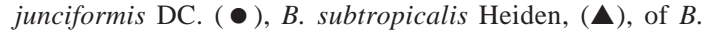
vincifolia Baker. ( ) in Rio Grande do Sul, Brazil.

alado, venuloso, ápice dos ramos com coloração avermelhada e limbo foliar desenvolvido. Os ramos jovens basais são muito distintos dos ramos reprodutivos, apresentando alas mais estreitas e limbo foliar oblongo ou ovalado de maiores dimensões. Ocasionalmente é identificada como $B$. glaziovii, mas esta se distingue pelo hábito arbustivo, folhas com base cuneada ou arredondada e panículas com ramos espiciformes curtos.

Lessing (1831a) descreveu Molina juncea com base no estudo de um espécime feminino e caracterizou-a, principalmente, pelas alas venulosas planas e longas, ramos 3-alados, com ápices ramificados em panículas amplas e piramidais, formadas por ramos espiciformes laterais, esparsos, divergentes e estreitamente alados em direção ao ápice, folhas desenvolvidas, subsésseis, membranáceas, ovaladas e agudas, invólucro feminino campanulado, filárias externas obtusas e internas agudas, com margens escariosas e denticuladas, clinanto aplanado e ovário oblongo e pubérulo. De Candolle (1836) transferiu $M$. juncea para Baccharis, propondo o nome novo $B$. junciformis, já que o epíteto específico juncea encontrava-se pré-ocupado.

Baker (1882) citou apenas o holótipo de B. junciformis como material examinado e descreveu a espécie como 5-alada, uma característica ausente na descrição original de 
Lessing (1831a). Baker (1882) também descreveu $B$. junciformis var. triptera, diferenciando-a pelos ramos 3-alados, uma característica também presente na diagnose de $M$. juncea. O holótipo de B. junciformis não foi localizado até o momento, enquanto que o isótipo encontra-se depauperado, estando representado por três fragmentos de caule, onde se pode observar a presença de três alas. As demais estruturas referentes aos ramos, folhas e capitulescências femininas estão ausentes no espécime. A comparação das diagnoses de $M$. juncea e $B$. junciformis var. triptera demonstra que ambos os táxons se referem à mesma espécie. O estudo do holótipo de $B$. junciformis var. triptera demonstrou que o espécime possui estruturas congruentes com a descrição de $B$. junciformis, abrangendo todas as características diagnósticas apontadas por Lessing (1831a) para esta espécie. Ademais, o estudo das diagnoses de $B$. junciformis e $B$. junciformis var. triptera, aliado ao estudo de espécimes em herbário e observações de campo, permitiu reconhecer este nome como prioritário ao nome $B$. usterii, uma espécie proposta por Heering (1911) com base em um espécime com apenas ramos vegetativos basais. Barroso (1976) aceitou o nome $B$. usterii e considerou $B$. junciformis uma espécie duvidosa, sem fazer menção a $B$. junciformis var. triptera.

Barroso (1976) e Barroso \& Bueno (2002) consideraram B. trimeroides um sinônimo de $B$. sagittalis, entretanto o exame da foto do tipo demonstra que o espécime corresponde à $B$. junciformis, dessa forma o táxon de Malme (1931) é tratado como um sinônimo desta espécie. A análise do protólogo e da imagem do holótipo de B. cordata, considerada uma espécie duvidosa por Barroso (1976), também confirmou a espécie proposta por Malagarriga (1957) como sinônimo de $B$. junciformis.

O epíteto se refere à semelhança do hábito da espécie com o gênero Juncus L. (Juncaceae) que também ocorre em habitats paludosos.
8. Baccharis microcephala (Less.) DC., Prodr. 5: 425. 1836. Molina microcephala Less., Linnaea 6: 142. 1831a. TIPO: BRASIL. RIO GRANDE DO SUL: [Uruguai, Montevideo] 1821/1822, F. Sellow d248 [H.I.B. 742] (holótipo não localizado; isótipos K; P-481997, foto!). Fig. 9 a-f Ilustrações adicionais: Cabrera (1974); Malagarriga (1977).

Arbustos 0,5-2,2 $\mathrm{m}$ alt., eretos, resinosos, indumento em diminutos tufos de tricomas flagelados unisseriados e tricomas bisseriados glandulares. Caule e ramos ereto, verde-acinzentados, ramos vegetativos e reprodutivos 3-alados, alas 3-11 $\times 0,2-0,4 \mathrm{~mm}$. Folhas escamiformes, sésseis, $1-$ 2×1-2 mm, oblongas. Ramos espiciformes 7$35 \mathrm{~cm}$ compr., terminais, laxos, ramos espiciformes laterais reduzidos a capítulos solitários ou glomérulos com 2-6 capítulos; brácteas escamiformes. Capítulomasculino 3,5-5×3,5-4,5 mm; invólucro globoso; filárias 4 séries, externas ovaladas, medianas ovaladas a elípticas, internas elípticas, ápice e margem estreitamente escariosos, curtamente denteados. Flores masculinas 1626; corola 2,5-2,7 mm compr., tubo 1,1-1,6 mm compr., fauce $0,1-0,2 \mathrm{~mm}$ compr., lacínias $0,5-$ $1 \mathrm{~mm}$ compr.; pistilódio 2,5-2,7 mm compr., ápice bífido, ramos coniventes; papilho 2,3-2,5 mm compr. Capítulo feminino 3-3,3 × 2,5-3,5 $\mathrm{mm}$; invólucro globoso; filárias 4 séries, externas ovaladas, medianas e internas elípticas, estreitamente escariosas. Flores femininas 25-60; corola 1-1,2 mm compr., curto-ligulada; estilete 1,5-1,8 mm compr. Cipselas 0,5-0,6 mm compr., oblongas, glabras, papilosas, 5-6 costadas; papilho 2-2,5 mm compr.

Material selecionado: BRASIL. RIO GRANDE DO SUL: Bom Jesus, 14.II.1947, fl., B. Rambo s.n. (PACA 35260). Cambará do Sul, 20.I.2000, fl., R. Wasum 417 (HUCS). Caxias do Sul, 19.II.2000, fl., A. Kegler 691 (HUCS). Osório, 21.II.1950, fl., B. Rambo s.n. (PACA 45959). São Francisco de Paula, fl., I.1943, P. Buck s.n. (PACA 11631). São José dos Ausentes, fl., 28.XII.1996, J.A. Jarenkow 3402 (PEL). São Lourenço do Sul, XI.2003, fl., G. Heiden 394, 400 (PEL).

Material adicional examinado: BRASIL. PARANÁ: São Mateus do Sul, 30.X.1985, fl., R.M. Britez 196 (RB). SANTACATARINA: Curitibanos, 22.II.1962, fl., R. Reitz 12231 (RB). São José, 13.IV.1961, fl., $R$. Reitz 10984 (RB). 


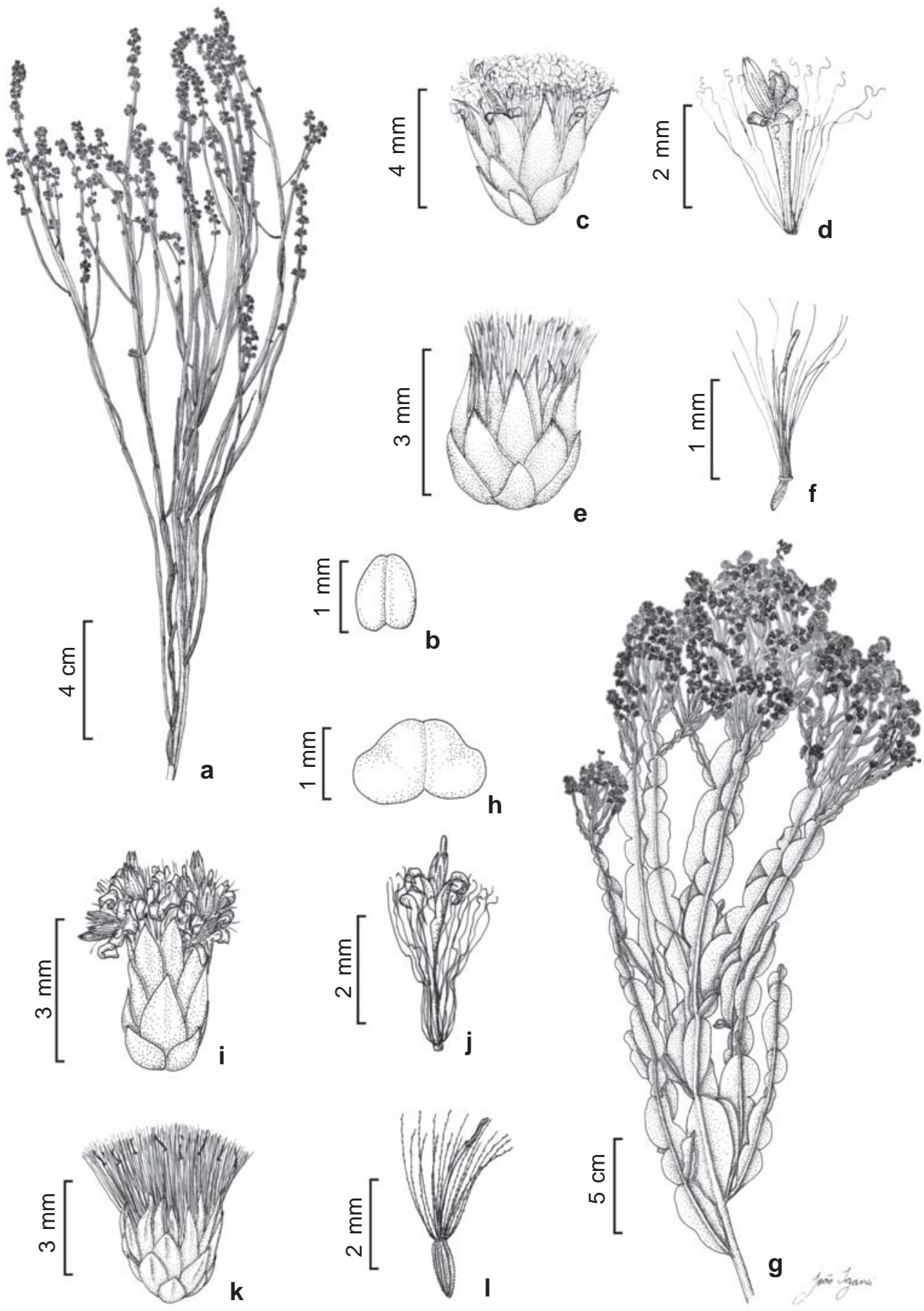

Figura 9-Baccharis microcephala (Less.) DC. - a. hábito; b. folha; c. capítulo masculino; d. flor masculina; e. capítulo feminino; f. flor feminina. Baccharis milleflora (Less.) DC. - g. hábito; h. folha; i. capítulo masculino; j. flor masculina; k. capítulo feminino; l. flor feminina f. capítulo masculino; g. flor masculina. (a-b, e-f Heiden 400; c-d Heiden 394; g-h, k1 Heiden 506; i-j Heiden 507).

Figure 9 - Baccharis microcephala (Less.) DC. - a. habit; b. leaf; c. male head; d. male floret; e. female head; f. female floret. Baccharis milleflora (Less.) DC. - g. habit; h. leaf; i. male head; j. male floret; k. female head; 1. female floret; f. capítulo masculino; g. flor masculina. (a-b, e-f Heiden 400; c-d Heiden 394; g-h, k-1 Heiden 506; i-j Heiden 507). 
Baccharis microcephala ocorre na Argentina, Paraguai, Uruguai e nas Regiões Sudeste (MG, SP) e Sul (PR, SC e RS) do Brasil. No Rio Grande do Sul é encontrada nos Campos de Cima da Serra, Encosta do Sudeste, Encosta do Nordeste e Litoral (Fig. 6). Ocorre desde áreas de baixa altitude na planície costeira interna, até altitudes superiores a 1000 $\mathrm{m}$ na Serra Geral. Forma populações densas e descontínuas em locais úmidos ou com água estagnada sob sol pleno, em áreas naturais, como campos temporariamente alagados, ou antropizadas, como beiras de estradas. Embora seja superficialmente semelhante às espécies mais comumente utilizadas na medicina popular, não há registros do uso com fins terapêuticos. Floresce de novembro a janeiro com dispersão das cipselas até fevereiro.

Baccharis microcephala assemelha-se à $B$. penningtonii quanto ao hábito arbustivo, habitat em áreas úmidas ou paludosas e alas caulinares estreitas e extensas. Todavia, $B$. microcephala possui capítulos solitários ou agrupados em glomérulos de 2-6, na extremidade e ao longo de ramos espiciformes laxos terminais, capítulos masculinos com menor número de flores e capítulos femininos menores, com menor número de flores e com corola, estilete e cipselas de menores dimensões; enquanto $B$. penningtonnii apresenta capítulos sésseis ou brevemente pedunculados, solitários ou em grupos de 2-3, constituindo ramos espiciformes terminais e axilares organizados em panículas terminais, capítulos masculinos com maior número de flores, capítulos femininos maiores, com maior número de flores e com corola, estilete e cipselas de maiores dimensões. O epíteto faz referência ao tamanho diminuto dos capítulos.

9. Baccharis milleflora (Less.) DC., Prodr. 5: 426. 1836. Molina milleflora Less., Linnaea 6: 143. 1831a. Baccharis genistelloides var. milleflora Baker in Mart., Fl. bras. 6(3):41. 1882. TIPO: BRASIL. F. Sellow s.n. (holótipo $\mathrm{B} \uparrow$; isótipos BR; G-DC; HBG; K; P, foto!; W).

Fig. 9 g-1

Ilustrações adicionais: Malagarriga (1977); Diesel (1987).
Arbustos 0,75-2 m alt., eretos; aparentemente glabros, indumento em diminutos tufos de tricomas flagelados unisseriados e tricomas glandulares bisseriados. Caule e ramos eretos, verdes, ramos vegetativos e reprodutivos 3 -alados, alas $0,5-8 \times 0,5-2 \mathrm{~cm}$, aplanadas. Folhas escamiformes, sésseis, 0,5-2 × 0,5-3,5 mm, obtusas. Panículas 10-25 cm compr.; ramos espiciformes $1-5 \mathrm{~cm}$ compr., ramos espiciformes secundários reduzidos a capítulos solitários ou agrupados 2-3; brácteas escamiformes. Capítulo masculino 3-4 ×3-3,5 mm; invólucro cilíndrico a campanulado; filárias 3-4 séries, externas e medianas ovaladas, internas elípticas, ápice e margem fimbriados. Flores masculinas 20-25; corola 2,3-2,8 mm compr., tubo 1-1,5 mm compr., fauce 0-0,1 mm compr., lacínias 1-1,2 mm compr.; estilete 2,3-3 mm compr., ápice indiviso; papilho 2,8-3,5 mm compr. Capítulo feminino 4-5,5 × 2,5-4,5 mm; invólucro cilíndrico a campanulado; filárias 4-5 séries, externas ovaladas, medianas elípticas e internas linearelípticas, ápice inteiro ou denticulado, margem estreitamente escariosa. Flores femininas 40 52; corola 1,8-2,2 mm compr., irregularmente denticulada ou curto-ligulada; estilete 2,2-3,2 mm compr. Cipselas 0,8-1,5 mm compr., cilíndricas, papilosas, 5-6 costadas; papilho 2,2-3,2 mm compr.

Material selecionado: BRASIL. RIO GRANDEDO SUL: Cambará do Sul, 27.XII.1988, fl., J.A. Jarenkow \& R.M. Bueno 1180 (PEL). Morrinhos do Sul, fl., J.A. Jarenkow \& M. Sobral 3294 (PEL).

Material adicional examinado: BRASIL. PARANÁ: Guarapuava, 11.XII.1973, fl., G. Hatschbach 33463 (RB). São Mateus do Sul, 16.X.2005, fl. e fr., $G$. Heiden 506 (RB); fl., G. Heiden 507 (RB). SANTA CATARINA: Bom Retiro, 11.XII.1973, fl., G. Hatschbach 33463 (RB). Rio do Sul, 16.X.1958, fl., R. Reitz 7285 (RB).

Baccharis milleflora ocorre nas Regiões Sudeste (SP) e Sul (PR, SC e RS) do Brasil. No Rio Grande do Sul é encontrada nos Campos de Cima da Serra e Encosta do Nordeste (Fig. 6). O estado é o limite meridional de distribuição da espécie. Frequentemente forma populações densas em formações abertas e ensolaradas, principalmente em solos rasos e úmidos, ou 
banhados e lajedos com água estagnada nos campos do planalto, também ocorre em áreas antropizadas e em sucessão secundária. A floração abundante e as populações densas atraem diversos insetos. Ocasionalmente é aplicada na medicina popular, de modo semelhante à B. articulata, B. crispa e B. myriocephala. Floresce de novembro a janeiro com dispersão das cipselas até fevereiro. Popularmente é conhecida como carqueja-do-lajeado.

Baccharis milleflora assemelha-se à $B$. apicifoliosa, como discutido previamente no presente estudo, podendo ser diferenciada através de características dos ramos férteis, capítulos, flores e cipselas. O holótipo da espécie provavelmente encontra-se destruído, sendo necessária a designação de um lectótipo. Entretanto é desejável o exame de uma amostragem mais abrangente dos isótipos, motivo pelo qual a indicação não foi realizada. $\mathrm{O}$ epíteto significa mil flores, relativo às numerosas inflorescências e flores.

10. Baccharis myriocephala DC., Prodr. 5: 426. 1836. TIPO: Brasil, Minas Gerais, 우, Vauthier 265 (lectótipo designado por Müller 2006a: G-DC, foto!; isolectótipos G, P-2, W).

Fig. $10 \mathrm{a}-\mathrm{f}$

Ilustração adicional: Borges \& Forzza (2008).

Subarbustos 1-2 m alt. ereto-patentes, escandentes ou prostrados; aparentemente glabros, indumento em diminutos tufos de tricomas clavados unisseriados e tricomas glandulares bisseriados. Caule e ramos flexuosos, ramos vegetativos e reprodutivos 3 -alados, alas $0,5-$ $1 \mathrm{~cm}$ compr., no caule principal 1-2 cm larg., nos ramos secundários, 0,5-1 cm larg., aplanadas a onduladas. Folhas escamiformes, sésseis, 0,10,5 $\times 0,1-0,7 \mathrm{~mm}$ larg., triangulares. Panículas 25-70 cm, laxas, raque com alas 0,4-0,8 cm larg.; ramos espiciformes $16-40 \mathrm{~cm}$, ramos espiciformes secundários reduzidos a glomérulos com 2-6 capítulos e capítulos solitários; brácteas escamiformes. Capítulo masculino 4-6 ×3$6 \mathrm{~mm}$; invólucro campanulado; filárias 3-5 séries, externas ovaladas, medianas elípticas, internas linear-elípticas, margem estreitamente escariosa, inteira. Flores masculinas 15-25; corola 34,5 mm compr., tubo $2-2,5 \mathrm{~mm}$ compr., fauce 0,1-0,5 mm compr., lacínias 1-1,5 mm compr.; estilete 3,5-4,7 mm compr., ápice indiviso; papilho 2,3-4 mm compr. Capítulo feminino 5-7×2,5-4 mm; invólucro cilíndrico; filárias 5-7 séries, externas ovaladas, medianas oblongas, internas linear-elípticas, ápice denticulado, margem estreitamente escariosa, inteira ou denticulada. Flores femininas $30-45$; corola $3-4,5 \mathrm{~mm}$ compr., truncada ou curto-ligulada, lígula desprovida de dentículos vestigiais; estilete 3,55,5 mm compr. Cipselas 0,6-1 mm compr., cilíndricas, papilosas, 12-20 costadas; papilho 3,5-5 mm compr.

Material selecionado: BRASIL. RIO GRANDEDO SUL: Cambará do Sul, 3.IX.1995, fl., R.A. Wasum s.n. (HUCS 10774). Canela, 26.IX.2003, fl., R.A. Wasum 1972 (HUCS). Montenegro, 21.IX.1949, fl., A. Sehnem 3878 (HUCS). Teutônia, 11.III.1992, fl., R.A. Wasum \& A. Jasper s.n. (HUCS 8193).

Material adicional examinado: BRASIL. PARANÁ: Curitiba, X.1964, L.T. Dombrowski 469 (RB). São Mateus do Sul, 16.X.2005, fl. e fr., G. Heiden 525, 526 (RB).

Baccharis myriocephala ocorre no Nordeste (BA), Sudeste (ES, MG, RJ, SP) e Sul (PR, SC e RS) do Brasil. No Rio Grande do Sul é encontrada nos Campos de Cima da Serra, Depressão Central, Encosta do Sudeste e Encosta do Nordeste (Fig. 11). Trata-se de uma espécie amplamente distribuída nas margens de formações sob influência da floresta ombrófila densa e floresta ombrófila mista no norte e nordeste do estado. Ocorre em áreas úmidas como bordas de mata ou margens de rios e também em áreas ruderais e locais antropizados. Embora seja amplamente utilizada na medicina popular, sendo alvo de extrativismo, a espécie não sofre exploração predatória, pois ocorre apenas a coleta de ramos vegetativos. Floresce de setembro a março dispersando as cipselas em seguida.

Baccharis myriocephala foi incluída na sinonímia de $B$. genistelloides subsp. crispa por Müller (2006a). Entretanto, essa espécie é considerada no presente estudo como um 

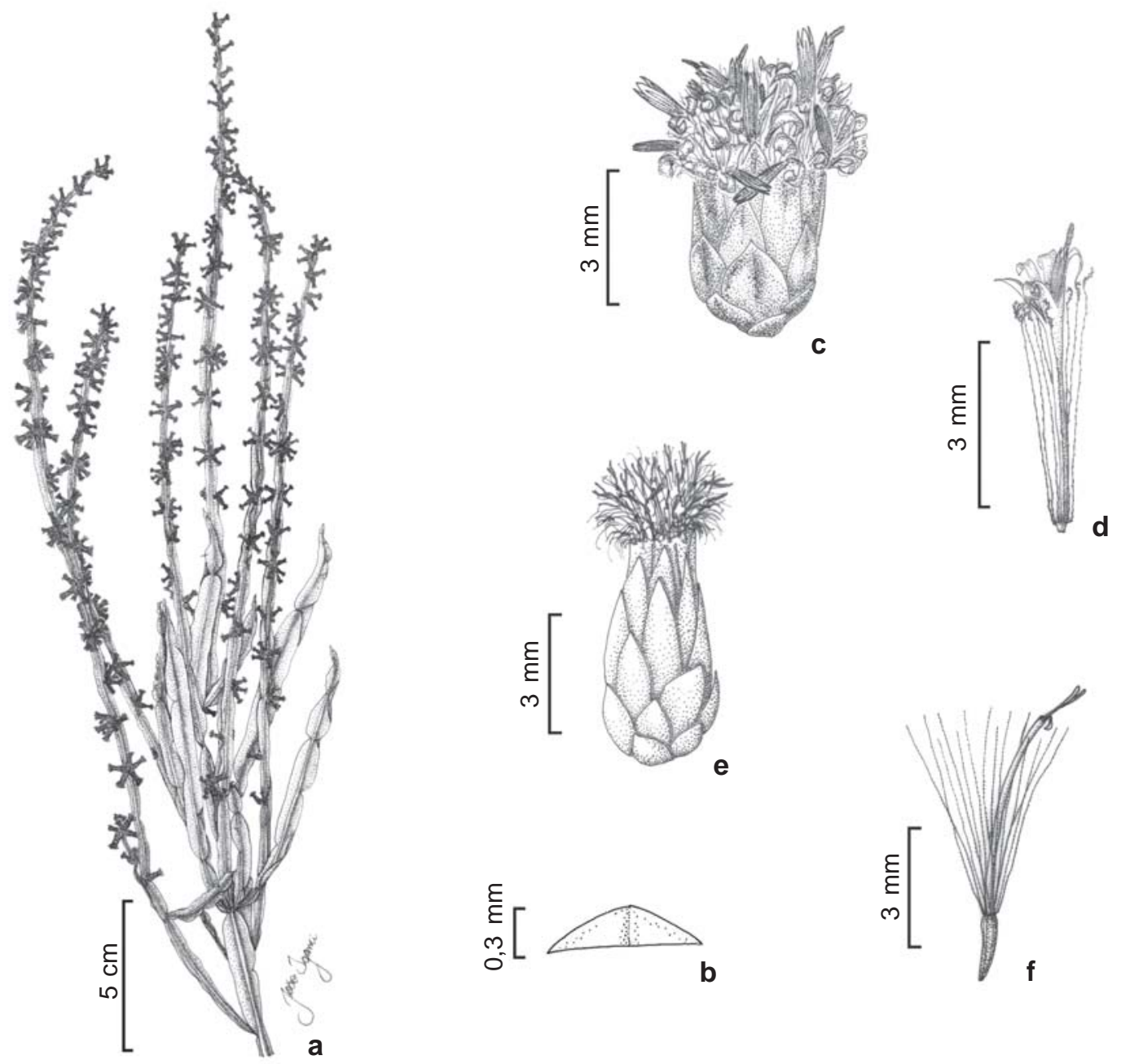

Figura 10 - Baccharis myriocephala DC. - a. hábito; b. folha; c. capítulo masculino; d. flor masculina e. capítulo feminino; f. flor feminina. (a-b, e-f Heiden 526; c-d Dombrowski 469).

Figure 10 - Baccharis myriocephala DC. - a. habit; b. leaf; c. male head; d. male floret; e. female head; f. female floret. (ab, e-f Heiden 526; c-d Dombrowski 469).

táxon próximo de $B$. crispa, porém distinto. Baccharis myriocephala é caracterizada por apresentar hábito subarbustivo escandente, ereto-patente ou prostrado, alas do caule principal com 1-2 cm larg., capítulo feminino com 5-7 mm comp., com 30-40 flores e cipselas $0,6-1 \mathrm{~mm}$ compr., enquanto que $B$. crispa apresenta hábito subarbustivo ereto, alas do caule principal com 0,3-1 cm larg., capítulo feminino com 4-5,5 mm compr., com 35-60 flores e cipselas 1-1,5 mm compr. Ambos os táxons apresentam área de dispersão ampla e muitas vezes ocorrem em simpatria, porém ocupando nichos ecológicos distintos. Enquanto B. crispa é um subarbusto heliófilo com ramos eretos e ocorrência exclusiva em vegetação campestre e áreas secundárias sob sol pleno, B. myriocephala ocorre preferencialmente como um arbusto apoiante ou escandente, às vezes epífita, em bordas e interior de matas, ou em encostas úmidas e sombreadas, raramente quando ocorre sob sol pleno, adquire a forma de um subarbusto com ramos prostrados. Não obstante, ocorre sobreposição de caracteres quantitativos entre estes táxons e a realização de estudos com 


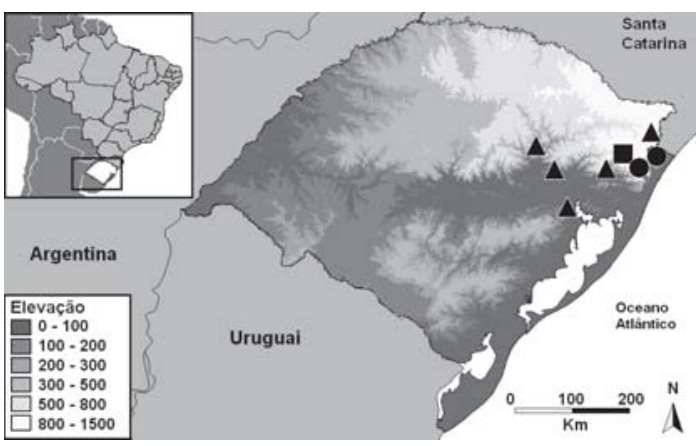

Figura 11 - Distribuição geográfica de Baccharis myriocephala DC. (A), B. organensis Baker (ם) e $B$. paranensis Heering \& Dusén $(\bullet)$ no estado do Rio Grande do Sul.

Figure 11 - Geographic distribution of Baccharis myriocephala DC. (A), B. organensis Baker (ם), and B. paranensis Heering \& Dusén $(\bullet)$ in Rio Grande do Sul, Brazil.

marcadores genéticos, visando constatar a ocorrência de hibridizações e introgressão gênica, é sugerido. O epíteto faz referência ao número elevado de capítulos nas inflorescências.

11. Baccharis organensis Baker, Fl. bras. 6(3): 74. 1882. TIPO: BRASIL. RIO DE JANEIRO: Serra dos Órgãos, A.F.M. Glaziou 6034 (lectótipo designado por Schneider et al. 2009: ICN!).

Fig. $12 \mathrm{a}-\mathrm{f}$

Ilustrações adicionais: Malagarriga (1977); Barroso \& Bueno (2002).

Arbustos 0,5-1,75 m alt., geralmente eretos, raramente apoiantes, aparentemente glabros, indumento em diminutos tufos de tricomas flagelados unisseriados e tricomas glandulares bisseriados. Caule e ramos eretos ou flexuosos, estriados. Folhas desenvolvidas, pecíolo 3-6 mm compr., lâmina 1,1-3,2×0,5$1,7 \mathrm{~cm}$, coriácea a cartácea, orbicular a oblonga, base arredondada a cuneada, ápice arredondado a agudo, 3 nervuras acródromas basais imperfeitas; face abaxial opaca, face adaxial resinosa. Panículas piramidais, axilares ou terminais, de ramos espiciformes, 0,5-3 cm compr., com 3-20 capítulos. Capítulo masculino 2,5-4 × 2,5-4 mm, invólucro campanulado, filárias 4-5 séries, externas e medianas ovaladas, internas elípticas, ápice denticulado a curtamente fimbriado, margem escariosa. Flores masculinas 16-28; corola 1,8-2 mm compr., tubo $1-1,2 \mathrm{~mm}$ compr., fauce $0,2-0,5 \mathrm{~mm}$ compr., lacínias 0,3-0,5 mm compr.; pistilódio 1,8-2,2 mm compr., ápice bífido, ramos breves; papilho 2-2,5 mm compr. Capítulo feminino 3,5-5 × 2,5-5 mm; invólucro cilíndrico a campanulado; filárias 3-4 séries, face abaxial com estria enegrecida, externas ovaladas, medianas elípticas, internas lineares, ápice denticulado a curtamente laciniado, margem denteada, escariosa. Flores femininas 30 42; corola 2-2,4 mm compr., 3-5-denticulada, estilete 2,5-3,2 mm compr. Cipselas 1,2-1,5 mm compr., cônicas ou oblongas, papilosas, 5 6 costadas; papilho 2-2,5 mm compr.

Material examinado: BRASIL. RIO GRANDEDO SUL: Cambará do Sul, 19.XII.1950, fl., A. Sehnem s.n. (PACA 50991); 18.XII.1950, fl., B. Rambo s.n. (PACA 49388), 13.XI.1953, fl., B. Rambo s.n. (PACA 54487).

Material adicional examinado: BRASIL. PARANÁ: Quatro Barras, 31.X.1989, fl., J.M. Silva \& C.B. Poliguesi 652 (HUCS). RIO DE JANEIRO: Itatiaia, 3.XII.1964, fl., M.C. Vianna 195 (RB). Teresópolis, 8.X.1929, fl., A.C. Brade 9637 (HAS), 27.IX.2007, fl., G. Heiden 899 (RB). SANTA CATARINA: Bom Jardim da Serra, 23.X.1958, fl., R. Reitz 7412 (RB); 16.X.2004, fl., J.M. Silva 4122 (RB).

Baccharis organensis ocorre nas Regiões Sudeste (MG, RJ, SP) e Sul (PR, SC e RS) do Brasil. No Rio Grande do Sul é encontrada nos Campos de Cima da Serra e Encosta do Nordeste (Fig. 11). Trata-se de uma espécie com ocorrência nas regiões de altitude da Serra Geral, onde vegeta nos campos do planalto ou em contatos entre estes campos e matas nebulares. O estado é o limite austral de distribuição da espécie e o número reduzido de coletas sugere uma raridade de distribuição e freqüência. Tais fatores sugerem a necessidade de avaliações pormenorizadas visando à inclusão na lista de espécies da flora ameaçadas de extinção no Rio Grande do Sul. Floresce de agosto a novembro com dispersão das cipselas logo em seguida. Popularmente é conhecida como alecrim. 

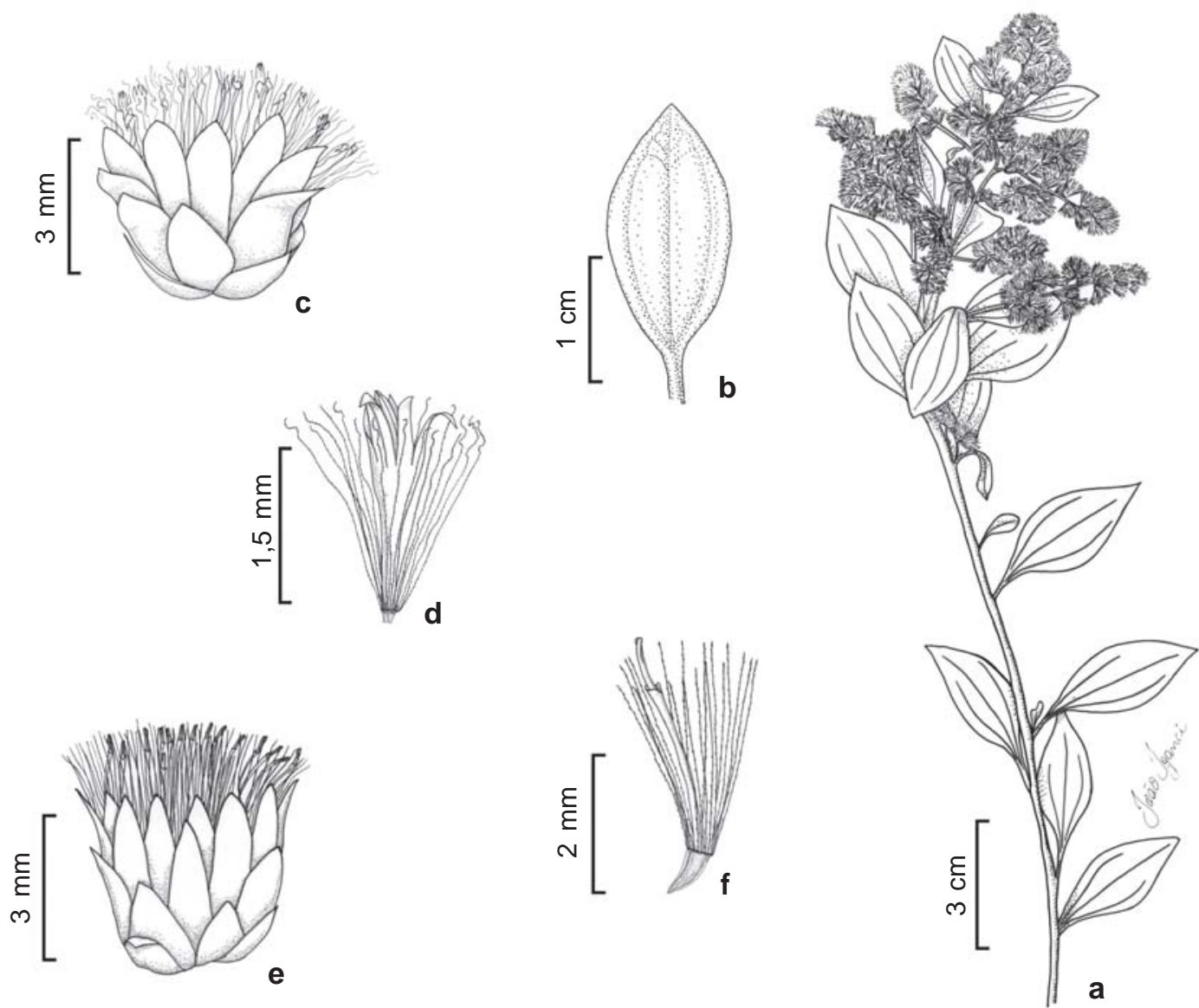

Figura 12 - Baccharis organensis Baker. - a. hábito; b. folha; c. capítulo masculino; d. flor masculina; e. capítulo feminino; f. flor feminina. (a-b, e-f Rambo s.n. (PACA 49388); c-d Rambo s.n. (PACA 54487)).

Figure 12 - Baccharis organensis Baker. - a. habit; b. leaf; c. male head; d. male floret; e. female head; f. female floret. (a-b, ef Rambo s.n. (PACA 49388); c-d Rambo s.n. (PACA 54487)).

Baccharis organensis é mais proximamente relacionada com B. paranensis. Essas espécies podem ser diferenciadas através de caracteres vegetativos e das cipselas. Baccharis organensis possui hábito arbustivo, pecíolo desenvolvido, folhas trinervadas com ápice arredondado, e cipselas cônicas a oblongas, com 5-6 costelas, enquanto que $B$. paranensis apresenta hábito arbustivo apoiante ou escandente, pecíolo mais curto, folhas peninérveas com ápice agudo a acuminado, e cipselas cilíndricas, com 8-12 costelas. O epíteto faz referência ao local de coleta do tipo, na Serra dos Órgãos, estado do Rio de Janeiro, Brasil.
12. Baccharis paranensis Heering \& Dusén, Arkiv. F. Bot. 9(15): 29. 1910. TIPO: BRASIL. PARANÁ: "inter Ypiranga et Volta Grande", 16.II.1904, P.K.O. Dusén 3667 (lectótipo designado por Barroso 1976: S, foto!; isolectótipo $\mathrm{R}$ !).

Fig. 13 a-f

Ilustrações adicionais: Dusén (1910); Malagarriga (1977).

Arbustos 0,5-1,5 m alt.; apoiantes ou escandentes, aparentemente glabros, indumento em diminutos tufos de tricomas flagelados unisseriados e tricomas glandulares bisseriados. Caule e ramos flexuosos, estriados. Folhas desenvolvidas, pecíolo 1-4 mm compr., lâmina $2-8 \times 2,5-4 \mathrm{~cm}$, coriácea 
a cartácea, ovalada a lanceolada, base aguda, ápice agudo a acuminado, peninérveas; face abaxial opaca, face adaxial resinosa. Panículas piramidais, axilares ou terminais, de ramos espiciformes 1-12 cm compr., com 3-15 capítulos. Capítulo masculino 2,5-3,5 ×2-4 mm; invólucro campanulado; filárias 4-5 séries, externas ovaladas, medianas oblongas, internas elípticas, margem escariosa. Flores masculinas 22-28; corola 2-2,5 mm compr., tubo 1,5-2 mm compr., fauce $0-0,1 \mathrm{~mm}$ compr., lacínias $0,5-1 \mathrm{~mm}$ compr.; pistilódio 2-2,5 mm compr., ápice inteiro; papilho 1,8-2,5 mm compr. Capítulo feminino 4-6×2-5 mm; invólucro cilíndrico a campanulado; filárias 4-5 séries, externas ovaladas, medianas elípticas, internas lineares, margem escariosa. Flores femininas 30-45; corola $2-2,3 \mathrm{~mm}$ compr., 5-denticulada; estilete 3,5-4 mm compr. Cipselas 0,9-1,2 mm compr., cônicas, papilosas, 8-12 costadas; papilho 3-5 mm compr. Material examinado: BRASIL. RIO GRANDE DO SUL: Morrinhos do Sul, 19.VIII.1995, fl., J.A. Jarenkow \& M. Sobral 2707 (PEL). São Francisco de Paula, 24.IX.1994, fl., R.A. Wasum s. n. (HUCS 10211).

Material adicional examinado: BRASIL. PARANÁ: São João, s.d., fl., P.K.O. Dusén 14394 (RB). SANTA CATARINA: Lauro Müller, 13.VII.1958, fl., R. Reitz \& R.M. Klein 6771 (RB); 21.VIII.2006, fl., G. Hatschbach \& E. Barbosa 79665 (MBM, RB).

Baccharis paranensis ocorre no Sul do Brasil (PR, SC e RS) e no Rio Grande do Sul é encontrada na Encosta do Nordeste (Fig. 11). O nordeste do estado é o limite meridional de distribuição da espécie, cuja ocorrência é registrada em encostas rochosas e bordas de floresta ombrófila mista e floresta ombrófila densa alto-montana, nos pontos culminantes da Serra Geral. A distribuição geográfica restrita e a raridade de coletas indicam a necessidade de estudos pormenorizados para inclusão na lista de espécies da flora ameaçada de extinção no Rio Grande do Sul. Floresce entre julho e fevereiro.

Baccharis paranensis é relacionada com $B$. organensis, como discutido previamente. Entretanto, é confundida com B. vincifolia da qual se diferencia pelas folhas coriáceas a cartáceas
( $v s$. cartáceas a membranáceas), capitulescências em ramos axilares e terminais ( $v s$. capitulescências em ramos axilares), e capítulos e flores menores (vs. capítulos e flores maiores). O epíteto faz referência ao estado do Paraná, Brasil, onde foi coletado o tipo.

13. Baccharis penningtonii Heering, Jahrb. Hamb. Wiss. Anst. Beih. 31: 119. 1915. TIPO: ARGENTINA. BUENOS AIRES: Delta del rio Paraná, 20.I.1903, o, M.S. Pennington 12 (holótipo HBG; isótipos MO, foto!, SP!).

Fig. 13 g-j

Ilustrações adicionais: Cabrera (1974); Malagarriga (1977).

Arbustos 1-2 m alt., eretos, resinosos, aparentemente glabros, indumento em diminutos tufos de tricomas flagelados unisseriados e tricomas bisseriados glandulares. Caule e ramos eretos, verde-acinzentados, ramos vegetativos e reprodutivos 3-alados, alas $1-8 \times 0,1-0,4 \mathrm{~cm}$, aplanadas. Folhas escamiformes, sésseis ou subsésseis, 0,05-1,5×0,05-1,5 mm., orbiculares. Panículas 10-16 cm compr., piramidais, terminais, de ramos espiciformes 3-6 cm compr., ramos espiciformes secundários reduzidos a 1-3 capítulos sésseis ou com pedúnculos $0-1,5 \mathrm{~cm}$ compr.; brácteas escamiformes. Capítulo masculino $3-4,5 \times 2,5-5 \mathrm{~mm}$; invólucro campanulado; filárias 4 séries, face abaxial com estria dorsal escura, externas ovaladas, medianas oblongas, internas ovalado-oblongas, margem escariosa, inteira. Flores masculinas 22-40; corola 2.5-3 mm compr., tubo 1-1.5 mm compr., fauce $0,1-0,5 \mathrm{~mm}$ compr., lacínias $1-1,5 \mathrm{~mm}$ compr.; pistilódio 2,5-3,5 mm compr., ápice bífido, ramos divergentes; papilho 2-3 mm compr. Capítulo feminino 3,5-5 × 3-5 mm; invólucro cilíndrico ou campanulado; filárias 3 4 séries, face abaxial com estria dorsal escura, externas ovaladas, medianas ovalado-oblongas, internas lineares, ápice denticulado, margem escariosa. Flores femininas 80-115; corola 1,5-2 mm compr., curto-ligulada; estilete 1,82,3 mm compr. Cipselas 0,5-1 mm compr., oblongas, papilosas, 4-5-costadas; papilho 22,5 mm compr. 


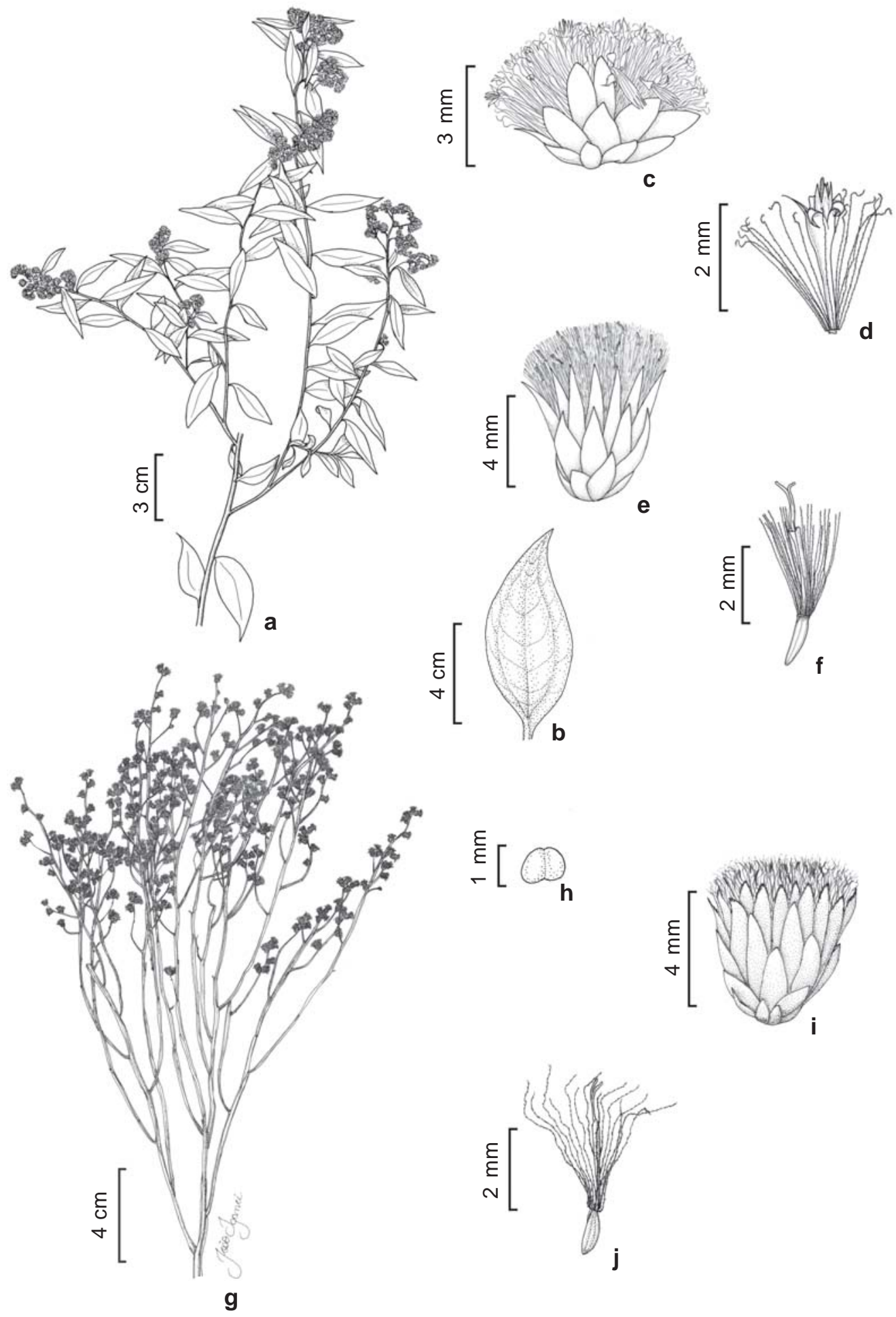

Figura 13 - a-f. Baccharis paranensis Heering \& Dusén. - a. hábito; b. folha; c. capítulo masculino; d. flor masculina; e. capítulo feminino; f. flor feminina. g-j. Baccharis penningtonii Heering - g. hábito; h. folha; i. capítulo feminino; j. flor feminina. (a-d Jarenkow \& Sobral 2707; e-f Wasum et al. s.n. (HUCS 10211); g-j Jarenkow 983).

Figure 13 - a-f. Baccharis paranensis Heering \& Dusén. - a. habit; b. leaf; c. male head; d. male floret; e. female head; f. female floret. g-j. Baccharis penningtonii Heering - g. habit; h. leaf; i. female head; j. female floret. (a-d Jarenkow \& Sobral 2707; e-f Wasum et al. s.n. (HUCS 10211); g-j Jarenkow 983). 
Material examinado: BRASIL. RIO GRANDEDO SUL: Capão do Leão, 4.XII.1957, J.C. Sacco 808 (PACA, PEL). Ijuí, 3.X.1953, J. Pivetta 336, 337 (PACA). Rio Grande, 15.X.1988, J.A. Jarenkow 983 (PEL). Tramandaí, 7.IV.1983, B. Irgang s.n. (ICN 53584). Uruguaiana, 3.XI.1973, J. Döbereiner 1040 (RB).

Material adicional examinado: ARGENTINA. CORRIENTES: Departamento de Itazuingó, 21.XI.1973, A. Lourteig 2921 (RB). URUGUAI. Departamento de Canelones, 29.X.1948, J.G. Kuhlmann s.n. (RB 64807).

Baccharis penningtonnii ocorre na Argentina, Uruguai e Região Sul (RS) do Brasil. No Rio Grande do Sul ocorre no Litoral e nas Missões (Fig. 14). Trata-se de uma espécie pouco comum no Brasil, cujo limite setentrional de distribuição geográfica encontra-se no Litoral e na fronteira oeste do Rio Grande do Sul. A ocorrência em áreas disjuntas do estado (Litoral e Missões) deve-se à contigüidade destas regiões com a província biogeográfica Pampeana, na Argentina e no Uruguai. Vegeta principalmente em ambientes úmidos como banhados e beira de rios. A drenagem de áreas úmidas e a ocupação destes ambientes pela orizicultura põem em risco a preservação desta espécie no Sul do Brasil. Baccharis penningtonii já consta na lista de espécies da flora do Rio Grande do Sul ameaçadas de extinção como vulnerável. Floresce de outubro a dezembro com dispersão das cipselas até abril.

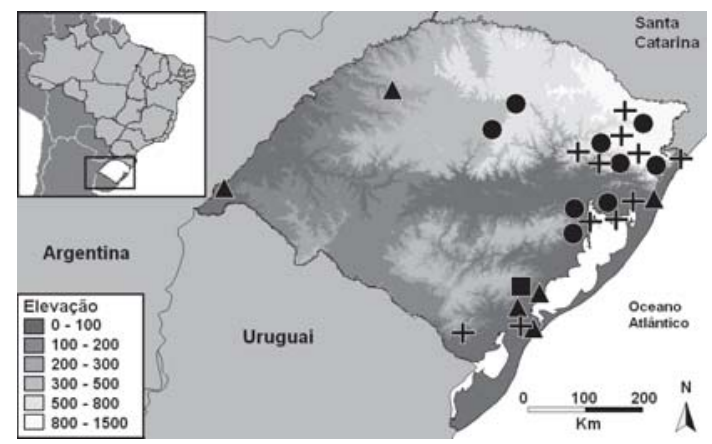

Figura 14 - Distribuição geográfica de Baccharis penningtonii Heering DC. (A), B. pentaptera (Less.) DC. (•), B. phyteumoides (Less.) DC. ( $\mathbf{0}$ ) e B. sagittalis (Less.) DC. (+) no estado do Rio Grande do Sul.

Figure 14 - Geographic distribution of Baccharis penningtonii Heering DC. ( $\mathbf{\Delta})$, B. pentaptera (Less.) DC. $(\bullet)$, B. phyteumoides (Less.) DC. ( $\square$ ), and B. sagittalis (Less.) DC. (+) in Rio Grande do Sul, Brazil.
Apesar das coletas existentes no estado, a espécie não havia sido incluída nos tratamentos de Barroso (1976) e Diesel (1987). Baccharis penningtonnii superficialmente lembra $B$. articulata devido ao hábito e coloração das alas, mas pode ser diferenciada pelos ramos 3-alados com alas estreitas e pouco interrompidas ( $v s$. ramos 2-alados, com alas geralmente mais largas e frequentemente constritas). A espécie mostra afinidades com B. microcephala, podendo ser diferenciada através de características dos capítulos e flores, conforme discutido previamente no presente estudo. O epíteto homenageia Miles Stuart Pennington, coletor do holótipo.

14. Baccharis pentaptera (Less.) DC. Prodr. 5: 425.1836. Molina pentaptera Less., Linnaea 6: 505. 1831a. TIPO: BRASIL. s.d., F. Sellow s.n. (holótipo não localizado; isótipo G-DC, foto!; K, foto!; P; W, foto!). Fig. 15 a-g

Baccharis stenocephala Baker in Mart., Fl. bras. 6(3): 39. 1882. TIPO: Brasil, São Paulo, campos do Morumbi, Burchell 4438 (síntipo C, foto!, P, foto !, W, foto!).

Baccharis fastigiata Baker in Mart., Fl. bras. 6(3): 39. 1882. TIPO: Brasil, Minas Gerais, pr. Cachoeira do Campo, P. Claussen 48 [Martii Herbar. Florae Brasil 747] (síntipo BR; G-DC, foto!; K; M; NY, foto!; P; W).

Ilustração adicional: Malagarriga (1977).

Subarbustos, xilopódio presente, 0,25$1 \mathrm{~m}$ alt., eretos; aparentemente glabros, indumento em diminutos tufos de tricomas flagelados unisseriados e tricomas bisseriados glandulares. Caule e ramos eretos, verde-claros ou cinzentos, ramos vegetativos 3-(5)-alados, ramos reprodutivos 2-alados, alas 0,3-10×0,2$0,4 \mathrm{~mm}$, aplanadas. Folhas desenvolvidas, subsésseis, 0,5-3×0,2-0,55 cm, lâmina orbicular a elíptica, na base dos ramos; escamiformes, sésseis, 1-3 × $1 \mathrm{~mm}$, triangulares, no ápice. Panículas piramidais de ramos espiciformes laxos, 2-23 cm compr., ramos espiciformes secundários com capítulos solitários ou glomérulos de 1-6 capítulos. Capítulo masculino 4-7×3-4 mm; invólucro cilíndrico; 

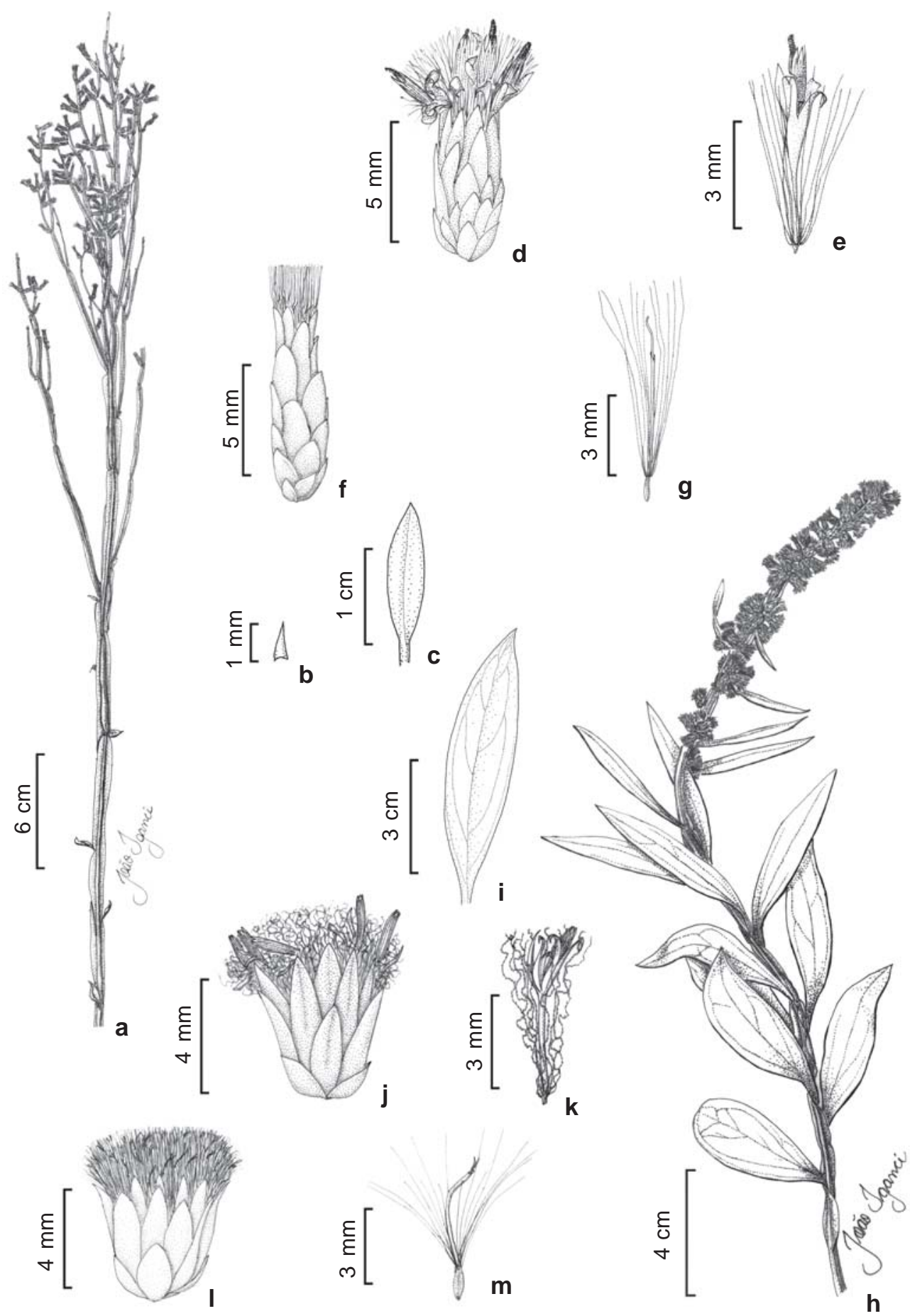

Figura 15 - a-g. Baccharis pentaptera (Less.) DC. - a. hábito; b-c. folhas; d. capítulo masculino; e. flor masculina; f. capítulo feminino; g. flor feminina. h-m. Baccharis phyteumoides (Less.) DC. - h. hábito; i folha; j. capítulo masculino; k. flor masculina; 1. capítulo feminino; m. flor feminina. (a, f-g Hoehne 2197; b-e Silva 1437; h-i, 1-m Egydio 55; j-k Rambo s.n. (PACA 4011)).

Figure 15 - a-g. Baccharis pentaptera (Less.) DC. - a. habit; b-c. leaves; d. male head; e. male floret; f. female head; g. female floret. h-m. Baccharis phyteumoides (Less.) DC. - h. habit; i. leaf; j. male head; k. male floret; 1 . female head; m. female floret. (a, f-g Hoehne 2197; b-e Silva 1437; h-i, 1-m Egydio 55; j-k Rambo s.n. (PACA 4011)). 
filárias 4-5 séries, externas ovaladas, medianas ovaladas a elípticas, internas elípticas, margem escariosa. Flores masculinas 10-15; corola 3-4 mm compr., tubo 2,2-2,5 mm compr., fauce 0,2-0,4 mm compr., lacínias 0,6-1 mm compr.; pistilódio 5-6,5 $\mathrm{mm}$ compr., ápice inteiro; papilho 4-5 $\mathrm{mm}$ compr. Capítulo feminino 8-12 × 2-3 mm; invólucro cilíndrico; filárias 6-9 séries, externas ovaladas a elípticas, medianas elípticas, internas elípticas a linearelípticas, margem estreitamente escariosa. Flores femininas 13-17; corola 5-6 mm compr., curto-ligulada, lígula 3-5-denticulada; estilete 5,2-8 mm compr. Cipselas 1,5-2 mm compr., cilíndricas, não papilosas, $3-5$ costadas; papilho 5,5-7 mm compr.

Material selecionado: BRASIL. RIO GRANDEDO SUL: Bom Jesus, 1.III.1936, fl., J. Dutra 1250 (ICN); Serra da Rocinha, 14.I.1942, fl., B. Rambo s.n. (PACA 8608). Caxias do Sul, 25.III.2000, A. Kegler 936(HUCS). Guaíba, 5.VII.2003, fl., C.S. Pires \& N.I. Matzenbacher MO6 (ICN). Porto Alegre, 18.XII.1948, fl., B. Rambo s.n. (PACA 38979). Santa Maria, 22.VIII.1939, fl., W. Rau 2147 (RB). Sertão Santana, 16.XII.1996, bt., J.A. Jarenkow 3317 (PEL). Soledade, 22.XII.1996, fl., J.A. Jarenkow 3342 (PEL).

Material adicional examinado: ARGENTINA. CORRIENTES: fl., A.J.A.G. Bonpland s.n. (RB 40319). BRASIL. MINAS GERAIS: Poços de Caldas, 7.III.1964, fl., J. Becker 315 (R). PARANÁ: São José dos Pinhais, 15.II.1995, fl., J.M. Silva 1437 (RB). SANTA CATARINA: São Joaquim, 29.II.1960, fl., J.R. Mattos 8755 (RB). SÃO PAULO: São Paulo, XII.1933, fl., A.C. Brade 12958 (RB); 28.II.1949, W. Hoehne 2197 (RB).

Baccharis pentaptera ocorre na Argentina e no Sudeste (MG, SP) e Sul (PR, SC e RS) do Brasil. No Rio Grande do Sul é encontrada nos Campos de Cima da Serra, Encosta do Nordeste, Encosta do Sudeste e Planalto Médio (Fig. 14). A revisão em herbários permitiu confirmar a ocorrência da espécie, cuja distribuição era documentada através da citação de material examinado na bibliografia apenas até Santa Catarina (como B. stenocephala). Vive em locais com solo raso e úmido ou com água estagnada, nos topos de morros ou planaltos em altitudes que variam de 300 a ca. $1000 \mathrm{~m}$. O Rio Grande do Sul é o limite meridional de distribuição da espécie que ocorre principalmente nos Campos de Cima da Serra e, mais raramente, no Planalto Médio e na porção setentrional da Encosta do Sudeste conhecida como Serra do Herval. Os habitats preferenciais da espécie vem sofrendo forte pressão antrópica devido às monoculturas agrícolas no Planalto Médio, e a expansão recente de monoculturas silviculturais nos remanescentes de vegetação campestre nativa dos Campos de Cima da Serra (Bioma Mata Atlântica) e da Serra do Sudeste (Bioma Pampa). É encontrada com botões a partir de julho e floresce de dezembro a abril.

Baccharis pentaptera é frequentemente confundida com $B$. articulata devido aos ramos 2-alados na inflorescência, entretanto pode ser diferenciada pelo xilópodio desenvolvido, hábito subarbustivo, ramos 3-5-alados na fase vegetativa e 3 -alados e 2 -alados na fase reprodutiva e capítulos femininos com invólucro cilíndrico 6-9 seriado. Baccharis pentaptera, nome considerado duvidoso por Barroso (1976), é o nome válido para B. stenocephala por prioridade como discutido por Schneider et al. (2009). O epíteto provavelmente faz referência ao número de alas encontrado nos ramos basais do holótipo, embora seja um caráter pouco comum.

15. Baccharis phyteumoides (Less.) DC., Prodr. 5: 425. 1836. Molina phyteumoides Less., Linnaea 6: 146. 1831a. TIPO: BRASIL [Brasilia Meridionalis], F. Sellow d501 (holótipo não localizado; isótipo W, foto!). Fig. 15 h-m

Baccharis phyteuma Heering, Jahrb. Hamburg. Wiss. Anst. Beih. 31: 128. 1913. TIPO: Argentina, Provincia de Buenos Aires, San Fernando, M.S. Pennington s.n. (holótipo HBG, foto!). Syn. nov.

Ilustrações adicionais: Cabrera (1941, 1963 , 1974); Malagarriga (1977); Diesel (1987).

Subarbustos 1-1,5 m alt., eretos, aparentemente glabros, indumento em diminutos tufos de tricomas flagelados unisseriados e tricomas glandulares bisseriados. Caule e ramos eretos, verdes, ramos vegetativos 3-(4)-alados, ramos reprodutivos 3-alados, alas 3-9 × 0,1-0,5 cm, aplanadas. 
Folhas desenvolvidas, subsésseis, lâmina lanceolada a linear-lanceolada, 4-8 $\times 0,5-2 \mathrm{~cm}$, membranáceas, base atenuada, ápice obtuso a agudo; peninérveas. Ramos espiciformes 8$15 \mathrm{~cm}$ cimpr., congestos, capítulos solitários ou em glomérulos; brácteas folhosas com lâmina linear. Capítulo masculino 4-6 × 4-5 mm; invólucro campanulado; filárias 3-4 séries, externas ovaladas, medianas ovaladas a elípticas, internas elípticas, ápice denticulado, margem escariosa. Flores masculinas 40-50; corola 4,5-5 mm compr.; tubo 3-3,5 mm compr., fauce 0-0,5 mm compr., lacínias 1,5-2 mm compr.; estilete 4,5-5 mm compr., ápice indiviso; papilho 3,5-4 mm compr. Capítulo feminino 5-6 ×3,5$4 \mathrm{~mm}$; invólucro oblongo; filárias 3-4 séries, externas ovaladas, medianas ovaladas a elípticas, internas elípticas, margem escariosa. Flores femininas 50-70; corola 4-4,5 mm compr., curtoligulada ou 3-5-denticulada; estilete 5-6,5 mm compr. Cipselas 1,5-2 mm compr., papilosas, 4-8 costadas; papilho 6-7,5 mm compr. Número cromossômico 2n=18 (Bowden 1945).

Material examinado: BRASIL. RIO GRANDE DO SUL: Pelotas, 2.II.1950, Ir. A. Egydio 55 (PEL); F. Sellow 974a [material misturado com Baccharis spicata e referido para o Rio Grande do Sul] (R 154242).

Material adicional examinado: ARGENTINA. CORRIENTES: Delta del Paraná, Arroyo Caraguata, 17.I.1931, A.L. Cabrera 1636 (SP). Departamento de Goya, Colonia Carolina, 23.XI.1979, A. Schinini et al. 19085 (ICN, RB). MISIONES: Departamento de San Ignacio, 18.XII.1945, J. Schwartz 1683 (ICN, RB). URUGUAI. DEPARTAMENTO DE RIVERA: Cuñapirú, 1.II.1941, B. Rambo s.n. (PACA4011).

Baccharis phyteumoides ocorre na Argentina, Paraguai, Uruguai e Região Sul (RS) do Brasil. No Rio Grande do Sul é encontrada na região fisiográfica Litoral (Fig. 14). Trata-se de uma espécie rara no Brasil, característica de ambientes ribeirinhos com deposição de sedimentos como margens de arroios, deltas e ilhas fluviais ou campos alagadiços, com ocorrência registrada apenas para o extremo-sul do Rio Grande do Sul. As poucas referências de coletas para o Brasil datam do século XIX, com um último registro posterior realizado em 1950. Em excursões de coleta recentes realizadas em
Pelotas e municípios circunvizinhos a espécie não foi encontrada. Devido à carência de registros recentes e ao elevado grau de antropização em que se encontra a área potencial de ocorrência da espécie, é provável que esteja ameaçada de extinção no território estadual, sendo conveniente que seja incluída na lista de espécies da flora ameaçadas no Rio Grande do Sul. Floresce de novembro a fevereiro.

Baccharis phyteumoides distingue-se pelas folhas desenvolvidas, membranáceas, peninérveas e dotadas de limbo lanceolado a linear-lanceolado e pelos capítulos em glomérulos formando uma espiga congesta. Heering (1916) descreveu $B$. phyteuma, cujas poucas coletas existentes são provenientes de áreas próximas a rios, principalmente deltas e ilhas fluviais nas províncias de Buenos Aires e Misiones, esta área de ocorrência está incluída completamente na distribuição conhecida de $B$. phyteumoides. Durante a análise de material foi constatada variação na largura das alas caulinares, de 1 a 5 $\mathrm{mm}$, entre indivíduos e no mesmo indivíduo. Quando comparada com B. phyteuma, não foram encontrados outros caracteres que diferenciassem as duas espécies, exceto a ausência ou presença de alas caulinares desenvolvidas. As evidências morfológicas, além da distribuição geográfica e preferências ecológicas coincidentes justificam a proposta de sinonimização. Não foram examinadas coletas com caule estriado provenientes do Brasil, por este motivo o caráter não foi considerado na chave, embora conste na descrição fornecida. $\mathrm{O}$ epíteto significa semelhante à Phyteuma L. (Campanulaceae).

16. Baccharis pseudovillosa Teodoro \& J.E. Vidal,Contrib. Inst. Geobiol. 2: 47.1952. Baccharis villosa Heering, Jahrb. Hamburg. Wiss. Anst. Beih. 31(3): 25. 1904, non Baccharis villosa Vahl, 1794. TIPO: BRASIL. SANTACATARINA: Capivari, acima da Serra Geral, ơ , E. Ule 1782 (holótipo HBG; isótipos GH; P-218332, foto!).

Fig. 16a-f

Ilustração adicional: Malagarriga (1977).

Subarbustos $0,5-0,75 \mathrm{~cm}$ alt., eretos, densamente pilosos, indumento viloso, tricomas 
filiformes unisseriados e tricomas glandulares bisseriados, destituídos de indumento em diminutos tufos. Caule e ramos eretos, ramos vegetativos e reprodutivos 3-alados, alas $1-9 \times 0,5-1 \mathrm{~cm}$, aplanadas. Folhas desenvolvidas, sésseis ou subsésseis, $0,5-1,5 \times 0,5-1,8 \mathrm{~cm}$, lâmina triangular a sagitada, raro ovalada, base truncada a cordada, ápice agudo, margem ciliada; 3 nervuras acródromas basais imperfeitas, nervura central proeminente. Ramos espiciformes 7-20 cm compr., ramos espiciformes secundários reduzidos a glomérulos nas inflorescências masculinas e femininas, às vezes desenvolvidos nas inflorescências masculinas; eixo das inflorescências com alas estreitas, 1-3 mm larg., brácteas 2-4× 1-2 mm. Capítulo masculino 4,5-7×3-4 mm; invólucro oblongo a campanulado; filárias 3-4 séries, externas e medianas pilosas, ovaladas, internas glabrescentes, elípticas, ápice fimbriado, margem escariosa. Flores 20-30; corola 4,5-5 mm compr., tubo $3-3,5 \mathrm{~mm}$ compr., fauce $0-0,2$ mm compr., lacínias $0,8-1,3$ mm compr.; pistilódio 6-7 mm compr., ápice indiviso, intumescido; papilho 3-4 mm compr. Capítulo feminino 4-6 $\times 2,5-3 \mathrm{~mm}$; invólucro oblongo a campanulado; filárias 3-4 séries, externas e medianas pilosas, ovaladas, internas glabrescentes, elípticas, margem fimbriada. Flores femininas 40-52; corola 3,2-4 mm compr., curto-ligulada, 3-5denticulada; estilete 4-5 mm compr. Cipselas 0,5-1 mm compr., oblongas, não papilosas, 8-10 costadas; papilho 4-5 mm compr.

Material examinado: BRASIL. RIO GRANDE DO SUL: Bom Jesus, 18.I.1950, fl., B. Rambo s.n. (ICN
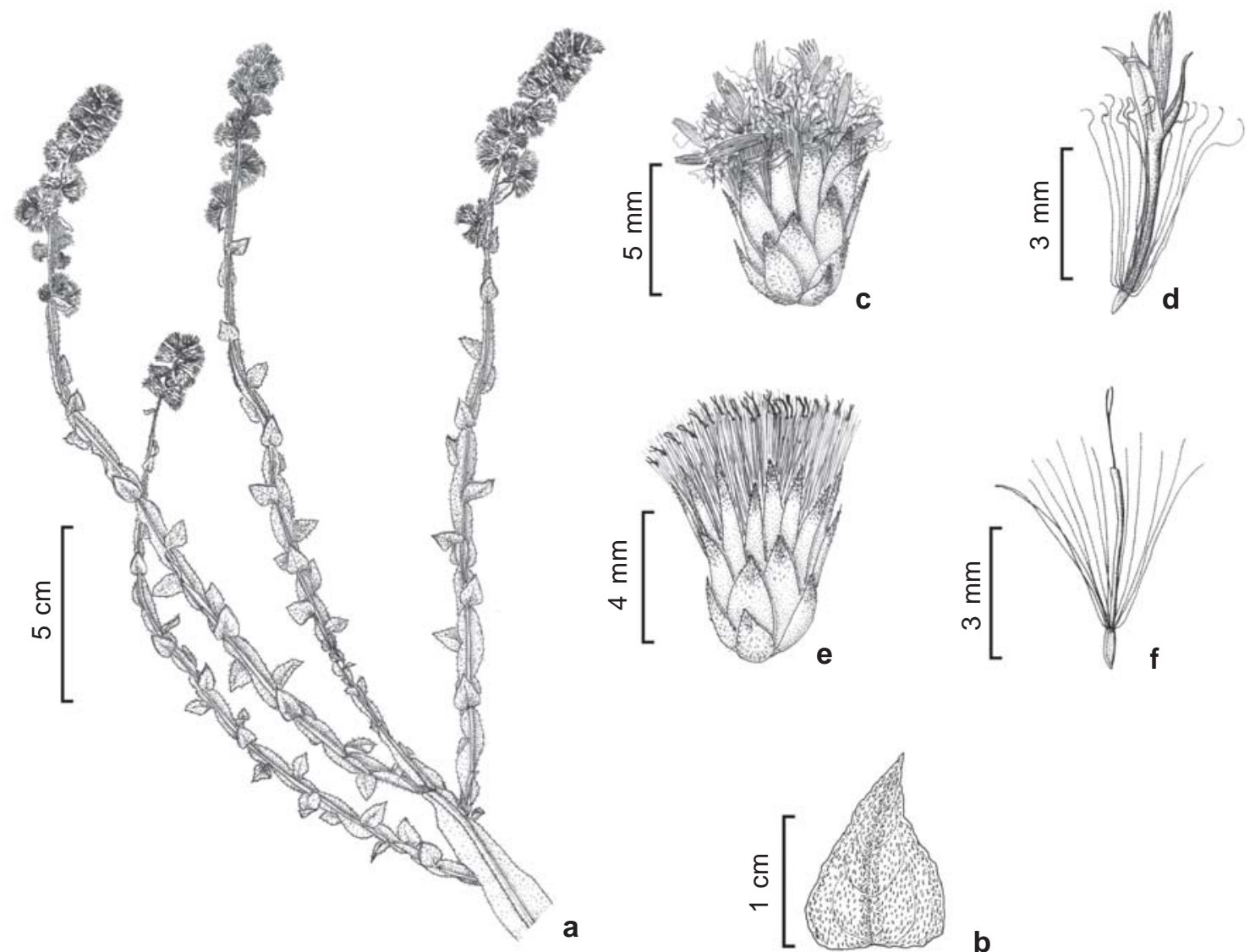

Figura 16 - Baccharis pseudovillosa Teodoro \& J.E.Vidal. - a. hábito; b. folha; c. capítulo masculino; d. flor masculina; e. capítulo feminino; f. flor feminina. (a-b, e-f Sehnem 4017; c-d Sehnem 3487).

Figure 16 - Baccharis pseudovillosa Teodoro \& J.E.Vidal. - a. habit; b. leaf; c. male head; d. male floret; e. female head; f. female floret. (a-b, e-f Sehnem 4017; c-d Sehnem 3487). 
69866); 19.I.1950, fl., A. Sehnem 4255 (HUCS, PACA, RB); 3.II.1953, fl., B. Rambo s.n. (PACA 53868). Montenegro, 15.XI.1948, fl., A. Sehnem 3487 (HUCS, PACA, RB). São Francisco de Paula, II.1948, fl., B. Rambo s.n. (PACA 36249), 13.VII.2002, fl., J. Paz 8 (ICN). São José dos Ausentes, 28.XII.1996, fl., J.A. Jarenkow 3436 (PEL).

Material adicional examinado: BRASIL. PARANÁ: União da Vitória, fl., V. Stawiarski s.n. (R 107853). SANTACATARINA: São Joaquim, 22.I.1950, fl., $R$. Reitz 3479 (RB). São José, 10.XI.1960, fl., R. Reitz 10392 (RB).

Baccharis pseudovillosa ocorre na Região Sul (PR, SC e RS) do Brasil. No Rio Grande do Sul é encontrada nos Campos de Cima da Serra e Encosta do Nordeste (Fig. 17). É característica de ambientes paludosos e turfeiras em regiões de altitude da Serra Geral onde forma populações abundantes acompanhando este tipo característico de ambiente. Ocasionalmente ocorre em formações semelhantes em altitudes mais baixas. O habitat restrito, aliado a fatores como a substituição de ambientes naturais por plantios silviculturais extensivos de Pinus L., assinala a necessidade de estudos visando definir o estado de conservação. Floresce a partir de julho estendendo a dispersão das cipselas até fevereiro.

Baccharis pseudovillosa carece do microindumento em tufos, característico das demais espécies da sect. Caulopterae, sendo diferenciada em virtude do indumento viloso conspícuo e persistente presente nas alas e folhas. A ausência de microindumento em tufos e o indumento viloso são distintivos da espécie e compartilhados apenas com B. palustris, espécie rara conhecida de duas coletas referidas para os estados de Minas Gerais (Regnell 1591) e Santa Catarina (Ule 1783), em área próxima da divisa com o Rio Grande do Sul. Baccharis pseudovillosa pode ser diferenciada de B. palustris vegetativamente devido ao caule alado ( $v s$. estriado) e limbo foliar triangular a sagitado e raro ovalado ( $v s$. oblongo a ovalado). O epíteto do basiônimo refere-se ao tipo de pilosidade das alas e folhas, o prefixo pseudo foi proposto por Malagarriga e Vidal ao verificarem que a combinação Baccharis villosa já havia sido utilizada por Vahl em 1790 para designar outra espécie.

Material adicional examinado de Baccharis palustris Heering, Jahrb. Hamburg. Wiss. Anst. Beih. 31(3): 25. 1904. BRASIL. MINAS GERAIS: A.F. Regnell, III.1591 (holótipo B†; F, foto!). SANTA CATARINA: Campo de Capivari, III.1891, E. Ule 1783 (P, foto!).

17. Baccharis ramboi Heiden \& Macias, Novon 19(2): 180. 2008. TIPO: BRASIL. RIO GRANDE DO SUL: Osório, Faz. do Arroio, 6.III.1950, ㅇ, B. Rambo SJ s.n. (holótipo PACA 46155!).

Ilustração: Heiden et al. (2008).

Subarbustos, 0,3-0,75 m alt., eretos, esparsamente pilosos, indumento híspido, tricomas simples unicelulares e tricomas glandulares bisseriados, destituídos de indumento em diminutos tufos. Caule e ramos eretos, ramos vegetativos e reprodutivos 3-alados, alas $0,75-7 \times 0,1-0,5 \mathrm{~cm}$, aplanadas. Folhas desenvolvidas, subsésseis, $0,5-1 \times 0,3-0,5 \mathrm{~cm}$, lâmina oblonga, base arredondada a cordada, ápice agudo, margem ciliada; peninérveas. Ramos espiciformes, 5$30 \mathrm{~cm}$ compr., ramos espiciformes secundários reduzidos a glomérulos com 1-5 capítulos; eixo da inflorescência com alas estreitas, 1-3 mm larg., brácteas 2-3×1-2 mm. Capítulo masculino 3,5-4×2,5-3 mm; invólucro oblongo; filárias 3-4 séries, externas ovaladas, medianas e internas linear-elípticas, ápice agudo, margem escariosa, fimbriada. Flores masculinas 20 25; corola 3,8-4,3 mm compr., tubo 2,8-3,3 mm compr., fauce $0,2-0,3 \mathrm{~mm}$ compr., lacínias $0,7-$ $1 \mathrm{~mm}$ compr.; pistilódio 4-5 mm compr., ápice levemente bífido, intumescido, ramos curtos, coniventes; papilho 4-4,5 mm compr. Capítulo feminino 4,5-5,3×2,5-3 mm; invólucro oblongo; filárias 4-5 séries, externas oblongo-ovaladas, medianas ovaladas, internas linear-elípticas, ápice agudo, margem escariosa, fimbriada. Flores femininas 28-35; corola 2,5-3,1 mm compr., curto-ligulada; estilete $4,5-5 \mathrm{~mm}$ compr. Cipselas 1-1,3 mm compr., oblongas, não papilosas, 5-8 costadas; papilho 3,5-4 mm compr. 
Material examinado: BRASIL. RIO GRANDEDO SUL: Cambará do Sul, 5.II.1948, fl., B. Rambo SJ s. n. (PACA36249; RB 414977). Montenegro, 2.X.1975, fl., Friedrichs 32914 (RB). Osório, 4.I.1950, fl., $B$. Rambo SJ s.n. (PACA 45168); 6.III.1950, fl., B. Rambo SJ s.n. (PACA 46135); 23.I.1958, fl., B. Rambo SJ s.n. (PACA 63561). São Francisco de Paula, I.1944, fl., P. Buck SJ s.n. (PACA 11632).

Material adicional examinado: BRASIL. SANTA CATARINA: Santa Cecília, 19.XII.1962, fl., R. Reitz \& R.M. Klein 14180 (RB 119353); I.1964, fl., E. Pereira 8370 \& G. Pabst 7645 (PEL). Campo Alegre, 9.IX.1956, fl., L.B. Smith 7473 (RB). São José, 24.I.1961, fl., R. Reitz 10707 (RB).

Baccharis ramboi ocorre na Região Sul do Brasil (SC e RS). No Rio Grande do Sul é encontrada nos Campos de Cima da Serra, Encosta do Nordeste e Litoral (Fig. 17). Vive principalmente em áreas úmidas e turfeiras nos campos do planalto e em formações campestres litorâneas e margens de lagoas próximas da borda da Serra Geral. A área de ocorrência potencial vem sendo reduzida devido aos plantios de Pinus L. em larga escala e ao potencial invasivo de mudas desta espécie sobre a vegetação nativa, além da colonização de áreas remotas do planalto com o aumento de assentamentos rurais e expansão das fronteiras agrícolas. Floresce de janeiro a março.

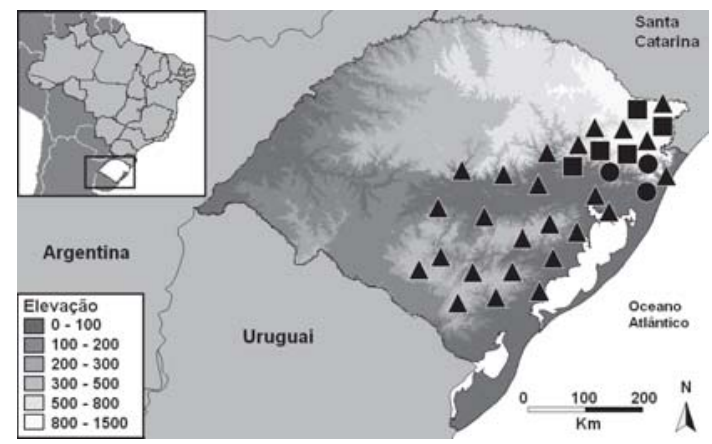

Figura 17 - Distribuição geográfica de Baccharis pseudovillosa Teodoro \& J.E.Vidal DC. ( ) , B. ramboi Heiden \& Macias (•) e B. riograndensis Teodoro \& J.E.Vidal. (A) no estado do Rio Grande do Sul.

Figure 17 - Geographic distribution of Baccharis pseudovillosa Teodoro \& J.E.Vidal DC. (ם), B. ramboi Heiden \& Macias (•), and B. riograndensis Teodoro \& J.E.Vidal. (ム) in Rio Grande do Sul, Brazil.
Baccharis ramboi se assemelha com $B$. pseudovillosa, entretanto, difere pelo indumento híspido ( $v s$. viloso), alas do caule mais estreitas (0,1-0,5 cm, vs. 0,5-1 cm), limbo das folhas oblongo ( $v s$. triangular), brácteas foliáceas ( $v s$. brácteas escamiformes), invólucro masculino oblongo ( $v s$. oblongo-campanulado) e ápice da corola das flores femininas curto-ligulada ( $v s$. denticulada). O epíteto homenageia o botânico gaúcho Pe. Balduíno Rambo S.J. (1905-1961), coletor do holótipo.

18. Baccharis riograndensis Teodoro \& J.E.Vidal, Bol. Inform. Inst. Geobiol. 1: 13. 1949b. TIPO: Brasil, Rio Grande do Sul, Santa Maria, Boca do Monte, III.1939, ㅇ, J. E. Vidal 37006 (lectótipo designado por Heiden \& Schneider 2008: R!).

Fig. 18 a-f

Ilustrações adicionais: Malagarriga (1977); Diesel (1987); Heiden \& Schneider (2008).

Subarbustos, 0,25-0,65 m alt., eretos, aparentemente glabros, indumento em diminutos tufos de tricomas clavados unisseriados e tricomas glandulares bisseriados. Caule e ramos eretos, ramos vegetativos e reprodutivos 3 -alados, alas $0,5-5 \times 0,25-0,75 \mathrm{~cm}$, onduladas nos ramos vegetativos, onduladas ou aplanadas nos ramos férteis com 1-2mm larg. Folhas escamiformes, sésseis, 1-2 × 1-2,5 mm, triangulares. Ramos espiciformes 5-25 cm compr., capítulos solitários ao longo dos ramos. Capítulo masculino 3,5-5,5 ×3,5-4 mm; invólucro campanulado; filárias 4-5 séries, externas oblongas, medianas ovaladas, internas curto-lanceoladas, ápice obtuso, inteiro ou curtamente denteado, margem estreitamente escariosa, inteira. Flores masculinas 18-30; corola 3-5 mm compr., tubo 2,8-3,3 mm compr., fauce 0,2-0,3 mm compr., lacínias 1,5-2 mm compr.; pistilódio 4-5 mm compr., ápice inteiro; papilho 4-5 mm compr. Capítulo feminino $7-10 \times 2-3 \mathrm{~mm}$; invólucro cilíndrico; filárias 4-7 séries, externas ovaladas, medianas e internas lineares, ápice dentículado, margem inteira, estreitamente escariosa. Flores femininas 30-40; corola 5-7 mm compr., 5denticulada; estilete 7-7,5 mm compr. Cipselas 

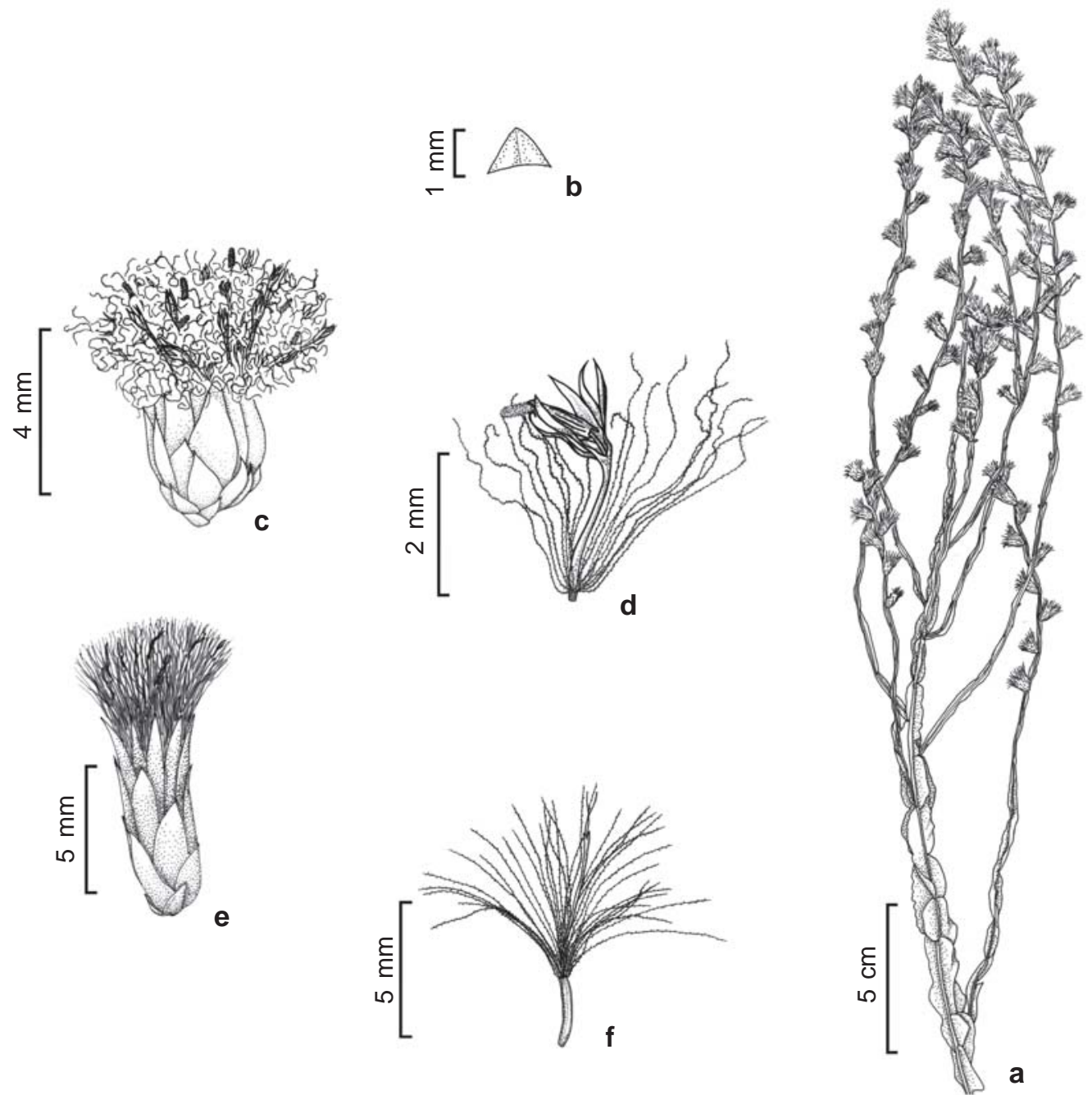

Figura 18 - Baccharis riograndensis Teodoro \& J.E.Vidal. - a. hábito; b. folha; c. capítulo masculino; d. flor masculina; e. capítulo feminino; f. flor feminina. (a-b, e-f Heiden 648; c-d Heiden 649).

Figure 18 - Baccharis riograndensis Teodoro \& J.E.Vidal. - a. habit; b. leaf; c. male head; d. male floret; e. female head; f. female floret. (a-b, e-f Heiden 648; c-d Heiden 649).

2,5-4 mm compr., cilíndricas, não papilosas, 12 20 costadas; papilho 7-8 mm compr.. Número cromossômico 2n=18 (Heiden et al. 2006b). Material selecionado: BRASIL. RIO GRANDEDO SUL: Bagé, 12.IV.1991, fl., M.R. Ritter 612 (ICN). Caçapava do Sul, 10.III.1982, fl., J. Mattos 23628 (HAS). Caxias do Sul, 12.II.2000, fl., A. Kegler 678 (HUCS). Osório, 14.IV.1950, fl., B. Rambo s.n. (PACA 46796). Pelotas, 8.III.1956, fl., O. Pereira s.n. (ICN 1469). Piratini, 8.IV.1991, fl., R.A. Wasum s.n. (HUCS 7575, 7576). Porto Alegre, 4.IV.1992, fl., L.T. Pereira 1 (ICN). Santa Maria, III.1939, fl., J.E. Vidal 37004 (R); 24.V.1960, fl., Irmão Teodoro Luis s.n. (SMDB 876, 884). São Francisco de Paula, 9.IV.2001, fl., R.A. Wasum 1049 (HUCS). São José dos Ausentes,
18.III.2002, fl., R.A. Wasum 1405 (HUCS). São Lourenço do Sul, III.2006, fl. e fr., G. Heiden 648 (RB), fl., G. Heiden 649 (RB).

Baccharis riograndensis ocorre na Região Sul do Brasil, sendo endêmica do Rio Grande do Sul, onde é encontrada na Campanha, Campos de Cima da Serra, Depressão Central, Encosta do Sudeste, Encosta do Nordeste, Litoral e Serra do Sudeste (Fig. 17). Vive em campos secos e pedregosos, principalmente na metade sul do estado (em afloramentos graníticos no bioma Pampa) e esparsamente na metade norte (em ilhas de campo de altitude inseridas em meio ao bioma Mata Atlântica em áreas do Planalto Sul-Brasileiro). 
Segundo Heiden \& Schneider (2008), encontrase quase ameaçada (NT), seguindo os critérios da IUCN (2001), devido ao incremento da pressão antropogênica sobre os Campos Sulinos com o aumento do uso da terra e a substituição da vegetação nativa por plantações silviculturais. Fértil entre dezembro e março; a dispersão de cipselas pode durar até junho. Conhecida popularmente como carqueja.

Baccharis riograndensis assemelha-se com B. crispa, quanto ao hábito, os ramos eretos, o invólucro campanulado do capítulo masculino e o papilho unisseriado nas flores masculinas e femininas. Difere de B. crispa devido aos ramos férteis estreitamente alados (vs. ramos férteis indistintamente alados), ramos espiciformes laterais reduzidos a capítulos solitários (vs. ramos espiciformes laterais completamente desenvolvidos ou com eixo reduzido constituindo um glomérulo), invólucro do capítulo feminino cilíndrico ( $v s$. campanulado) e cipselas 2,5-4 mm compr. ( $v s$. 1-1,5 mm compr.). O epíteto faz referência ao estado do Rio Grande do Sul.

19. Baccharis sagittalis (Less.) DC., Prodr. 5: 425. 1836. Molina sagittalis Less., Linnaea 6: 144. 1831a. Baccharis sagittalis var. poeppigii DC., Prodr. 5: 425. 1836. Pingraea sagittalis (Less.) F.H.Hellw., Candollea 48: 218. 1993. TIPO: CHILE. Valparaíso, 우, Poeppig 210 (lectótipo designado por Müller 2006a: G-DC, ox, foto!; isolectótipo MO-2x).

Baccharis heeringiana Teodoro, Contr. Inst. Geobiol. 3: 6. 1954 [sphalm heeringeana]. TIPO: Brasil, São Paulo, São Paulo, Campo Congonhas, Baccharis usterii x Baccharis milleflora, ㅇ, 24.III.1946, Hoehne 1948 (lectótipo aqui designado RB!; isolectótipos ICN!, SP!). Syn. nov.

Baccharis macroptera D.J.N. Hind, Kew Bull. 48(2): 261. 1993. TIPO: Brasil, Bahia, Água Quente, Pico das Almas, Vertente Norte, vale ao noroeste do pico, $1500 \mathrm{~m}$, beira de rio, 우, 20.XII.1988, R.M. Harley 27311 (holótipo SPF, foto!; isótipos CEPEC!; K, foto!; SP!). Syn. nov.

Ilustrações: Cabrera (1971); (Malagarriga 1977); Hind (1993); Müller (2006a).
Subarbustos 1-3 m alt., aparentemente glabros, indumento em diminutos tufos de tricomas flagelados unisseriados e tricomas glandulares bisseriados. Caule e ramos eretos ou eretopatentes, ramos vegetativos e reprodutivos 3alados, alas 0,5-2,5 ×6-15 cm, aplanadas ou levemente onduladas, venulosas. Folhas sésseis, lâmina $0,5-1,5 \times 0,2-0,5 \mathrm{~cm}$, papiráceas, oblongosagitada, base arredondada a sagitada, ápice obtuso, apiculado, margem inteira; uninérveas. Ramos espiciformes 7-25 cm compr. Capítulo masculino 6,5 $\times 9$ mm compr:; invólucro oblongo; filárias 4-6 séries, externas oblongas, medianas e internas lanceoladas, margem escariosa. Flores masculinas 20-35; corola 5,2-6 mm compr., tubo $3-5,3 \mathrm{~mm}$ compr., fauce $0,1-0,3 \mathrm{~mm}$ compr., lacínias 1,5-2 mm compr.; estilete 5,5-7 mm compr. ápice bífido, ramos lanceolados; papilho 4,5-6,5 mm compr. Capítulo feminino 5,89,1 ×3-5 mm; invólucro cilíndrico; filárias 5-7 séries, externas oblongas, medianas ovaladas, internas lanceoladas, margem escariosa. Flores femininas 57-152; corola 2,7-5 mm compr., curto-ligulada; estilete 4-6,5 mm compr. Cipselas 1-1,5 mm compr., ovaladas, papilosas, 6-9 costadas; papilho 3-5,5 mm compr.

Material selecionado: BRASIL. RIO GRANDEDO SUL: Bom Jesus, 4.I.1993, L.T. Pereira 67 (ICN). Canela, II.1953, K. Emmrich s.n. (PACA52875). Nova Roma do Sul, 28.XII.1993, L.T. Pereira 48 (ICN). São Francisco de Paula, 31.XII.1961, A. Sehnem 7958 (RB). Torres, 13.VII.1972, J. Lindeman et al. s.n. (ICN 28238). Vacaria, 4.I.1994, L.T. Pereira 64 (ICN). Viamão, 27.IV.2006, R. Trevisan 625 (ICN).

Material adicional examinado: BRASIL. BAHIA: Água Quente, Pico das Almas, 20.XII.1988, Harley et al. 27311 (SPF, holótipo de B. macroptera D.J.N. Hind; CEPEC, SP, K, foto, isótipos). MINAS GERAIS: Serra do Espinhaço, 20.II.1969, H.S. Irwin et al. 1969 (RB). SANTACATARINA. Palhoça, Pilões, 4.V.1956, R. Reitz \& R. M. Klein 3171 (HBR, RB). SÃO PAULO. São Paulo, III.1946, W. Hoehne 1957, 1959 (ICN, RB, síntipo de B. heeringiana Teodoro).

Baccharis sagittalis ocorre na Argentina, Bolívia, Chile, Equador, Paraguai, Peru e Regiões Nordeste (BA), Sudeste (MG, SP) e Sul (PR, SC, RS) do Brasil. No Rio Grande do Sul é encontrada nos Campos de Cima da Serra, Encosta do Sudeste, Encosta do Nordeste e 
Litoral (Fig. 14). Distribui-se na porção ocidental do estado desde o nível do mar, no Litoral, até altitudes superiores a $1000 \mathrm{~m}$, na Encosta do Nordeste e nos Campos de Cima da Serra. Ocupa habitats paludosos ou com umidade constante em campos úmidos, banhados e bordas de matas. Embora se assemelhe superficialmente às espécies mais comumente utilizadas na medicina popular não há registros do uso com fins terapêuticos. Floresce de dezembro a março com dispersão dos frutos até julho.

Baccharis sagittalis foi tratada por Malagarriga (1952), Barroso (1976) e Barroso \& Bueno (2002) como duvidosa no sul do Brasil, provavelmente por ocorrer descontinuamente em uma ampla área na América do Sul. Estes autores ao citarem a ocorrência de $B$. sagittalis para o Brasil, listaram na realidade material correspondente apenas a $B$. sagittalis var. montenvidensis $(=B$. subtropicalis Heiden). Desta forma, no presente estudo, a ocorrência de $B$. sagittalis é confirmada para o Brasil, através do estudo de material em herbários e da citação de material examinado congruente com a descrição original e o tipo. Além disso, B. sagittalis var. montevidensis não é aceita como um táxon subordinado a $B$. sagittalis, sendo reconhecida como uma espécie autônoma conforme discutido a seguir.

O correto reconhecimento de $B$. sagittalis, aliado ao estudo dos tipos e o exame de material proveniente de toda a área de ocorrência da espécie no Brasil, demonstrou que a aplicação equivocada deste binômio aos espécimes de $B$. subtropicalis, acarretou na proposição de novos táxons no país para essa mesma espécie, como atestam o material tipo de $B$. heeringiana e B. macroptera. Malagarriga (1954) descreveu $B$. heeringiana e listou três coleções como tipos. Entretanto, todos os espécimes estudados por Malagarriga (1954) correspondem a $B$. sagittalis, sendo por esse motivo proposta a sinonimização. O espécime Hoehne 1948 é aqui designado como lectótipo de $B$. heeringiana por portar capítulos em melhor estado de conservação. Da mesma forma, Hind (1993) propôs $B$. macroptera como um novo táxon endêmico da Bahia, entretanto o exame do material tipo demonstra que o mesmo também corresponde a $B$. sagittalis, sendo também indicada a sinonimização desse binômio.

Baccharis sagittalis se assemelha quanto ao hábito e habitat à $B$. junciformis, entretanto pode ser diferenciada pelas folhas uninérveas menores ( $v s$. trinérveas maiores). $\mathrm{O}$ epíteto fas referência às folhas com limbo sagitado.

20. Baccharis subtropicalis Heiden, nom. et stat. nov. Baccharis sagittalis var. montevidensis Baker in Mart., Fl. bras. 6(3): 42. 1882, non Baccharis montevidensis Spreng., 1826. TIPO: URUGUAI. Montevideo, XI.1874, Arechavaleta 4089 (lectótipo K, aqui designado, foto!).

Fig. 19 a-g

Subarbustos $0,3-0,8 \mathrm{~m}$ alt., eretos; aparentemente glabros, indumento em diminutos tufos de tricomas flagelados unisseriados e bisseriados glandulares. Caule e ramos eretos, verde-acinzentados, ramos vegetativos e reprodutivos 3-alados, alas $0,3-1,5 \times 0,3-1 \mathrm{~cm}$, aplanadas. Folhas desenvolvidas ou escamiformes; desenvolvidas subsésseis, 0,5$2,5 \times 0,3-1,2 \mathrm{~cm}$, elípticas, ovaladas ou obovadas, nunca triangulares, base arredondada, ápice agudo ou arredondado, cartáceas ou coriáceas, peninérveas ou uninérveas; escamiformes subsésseis, 1-4 × 1-4 mm, orbiculares, oblongas ou ovaladas, nunca triangulares. Ramos espiciformes $0,5-15 \mathrm{~cm}$ compr., ramos espiciformes secundários reduzidos a glomérulos com 2-8 capítulos; brácteas escamiformes. Capítulo masculino 4-5×3-5 mm; invólucro campanulado; filárias 3-5 séries, externas ovaladas a obtusas, medianas ovaladas a elípticas, internas elípticas a lineares, margem largamente escariosa, denticulada. Flores masculinas 20-33; corola 3,5-5,5 mm compr., tubo 2-4 mm compr., fauce 0,2 mm compr., lacínias 1,5-2 mm compr.; pistilódio 3,5-6 mm compr., ápice bífido, ramos divergentes; papilho 3,5-5 $\mathrm{mm}$ compr. Capítulo feminino 5-7 ×2,5-4 mm; invólucro cilíndrico, globoso na base; filárias 4-6 séries, externas ovaladas a obtusas, medianas ovaladas a elípticas, internas elípticas a lineares, margem 


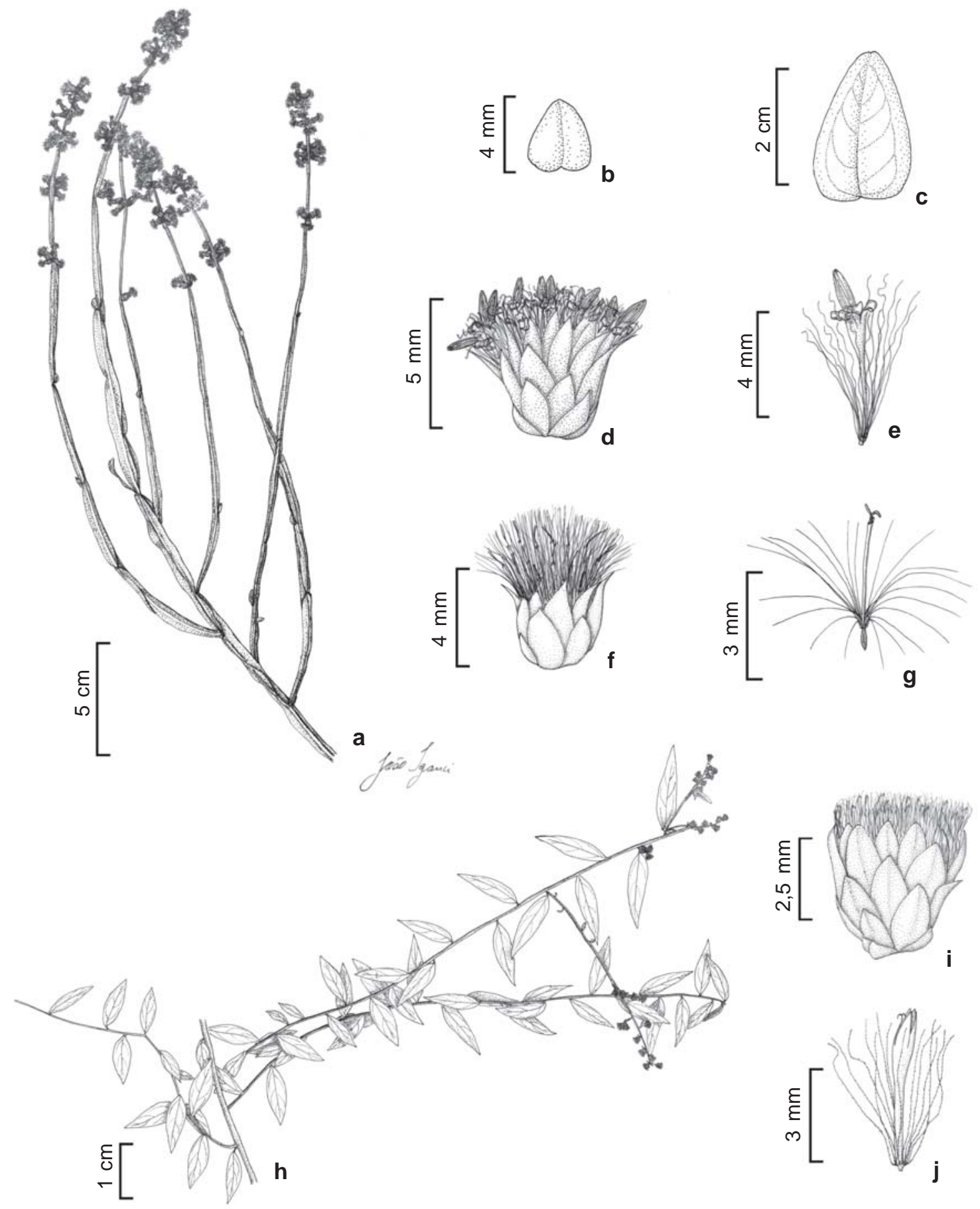

Figura 19 - a-g. Baccharis subtropicalis Heiden. - a. hábito; b-c. folhas; d. capítulo masculino; e. flor masculina; f. capítulo feminino; g. flor feminina. h-j. Baccharis vincifolia Baker - h. hábito; i. capítulo masculino; j. flor masculina. (a-c, f-g Heiden 696; d-e Heiden 697; h-j Hatschbach 24520).

Figura 19 - Baccharis subtropicalis Heiden. - a. habit; b-c. leaf; d. male head; e. male floret; f. female head; g. female floret. h-j. Baccharis vincifolia Baker - h. habit; i. male head; j. male floret. (a-c, f-g Heiden 696; d-e Heiden 697; h-j Hatschbach 24520). 
escariosa, denticulada. Flores femininas 30-55; corola 2,5-5 mm compr., curtamente ligulada ou truncada; estilete 3-5,5 $\mathrm{mm}$ compr. Cipselas $0,5-1 \mathrm{~mm}$ compr., cilíndricas, comprimidas lateralmente, papilosas, 6-8 costadas; papilho 2,5-6,5 mm compr.

Material selecionado: BRASIL. RIO GRANDE DO SUL: Cambará do Sul, 1.III.1986, fl., M. Sobral s.n. (ICN 86349). Capão do Leão, 12.XII.2002, fl., G. Heiden 288 (PEL). Caxias do Sul, 12.I.2000, fl., A. Kegler 554 (HUCS). Jaguarão, 8.II.1938, fl., B. Rambo s.n. (PACA 29795). Passo Fundo, fl., XII.1955, Frediani s.n. (PACA 57363). Pelotas, 25.I.1950, fl., I.E. Maria s.n. (ICN 17262). Quintão, 12.II.1996, fl., V.L. Gonçalvez 164 (HASU). Rio Grande, 30.I.1950, f1., I.E. Maria 11060 (ICN). São Lourenço do Sul, 25.XII.2002, fl., G. Heiden 293 (PEL); 1.III.2007, fl., G. Heiden 696, 697 (RB). São José dos Ausentes, I.2002, fl., M. Sobral et al. 9497 (ICN).

Material adicional examinado: BRASIL. PARANÁ: Paranaguá, 28.V.1964, fl., G. Hatschbach 11306 (RB). SANTACATARINA: Florianópolis, 20.1.1971, fl., A. Bresolin 123 (RB). URUGUAI. Montevideo, Gibert 720, 722, 807 (K: síntipo, foto!);

Baccharis subtropicalis ocorre no Uruguai e Região Sul do Brasil (PR, SC e RS). No Rio Grande do Sul é encontrada no Alto Uruguai, Campos de Cima da Serra, Depressão Central, Encosta do Sudeste, Encosta do Nordeste, Litoral e Serra do Sudeste (Fig. 8). Distribui-se na porção ocidental do estado desde o nível do mar, na região fisiográfica Litoral, até altitudes superiores a $1000 \mathrm{~m}$, na Encosta do Nordeste e nos Campos de Cima da Serra. Os habitats ocupados variam desde dunas, campos secos ou úmidos, áreas alagadiças ou pantanosas e mesmo áreas antropizadas, sempre em formações abertas como campos e banhados. A diversidade de habitats ocupados resulta em grande plasticidade fenotípica. Embora se assemelhe superficialmente às espécies mais comumente utilizadas na medicina popular, não há registros do uso com fins terapêuticos. Floresce de novembro a janeiro com dispersão dos frutos até março.

Baccharis subtropicalis é uma espécie distinta e com afinidades pouco evidentes. A espécie corresponde a $B$. sagittalis var. montevidensis, entretanto a ausência de afinidades morfológicas com $B$. sagittalis e a presença de características diferenciais relativas ao hábito, alas, folhas, capitulescências, capítulos, caracteríticas florais e frutos justificam a proposta de alteração de status e reconhecimento como uma espécie autônoma. Como o epíteto montevidensis já se encontra ocupado por $B$. montevidensis Spreng. [= Vernonanthura montevidensis (Spreng.) H.Rob.], é proposto o novo nome $B$. subtropicalis. Alguns espécimes com capítulos jovens são encontrados em herbários determinados como B. microcephala, devido à dimensão reduzida dos capítulos. Entretanto, o hábito geralmente arbustivo e as folhas reduzidas a escamas sésseis com $1 \times$ 1-2 mm compr., permitem reconhecer $B$. microcephala, mesmo estéril, pois $B$. subtropicalis apresenta hábito subarbustivo e folhas desenvolvidas na base da planta ou reduzidas a escamas subsésseis com 1-3 $\times$ 1-4 mm compr. O epíteto faz referência à área de distribuição da espécie na América do Sul subtropical.

21. Baccharis vincifolia Baker, Fl. bras. 6(3): 83. TIPO: URUGUAI. Montevideo, 1836, $F$. Sellow 4453 (lectótipo designado por Barroso 1976: K, foto!).

Fig. $19 \mathrm{~h}-\mathrm{j}$

Subarbustos 1-1,5 m alt., apoiantes ou escandentes, aparentemente glabros, mas com indumento em diminutos tufos de tricomas. Caule e ramos flexuosos, 3-4-estriados. Folhas desenvolvidas, pecíolo 1-3 mm compr., lâmina 3-7 × 0,5-2 cm, cartácea a membranácea, lanceolada, base aguda, ápice agudo ou acuminado; peninérvea; face abaxial opaca, face adaxial resinosa. Ramos espiciformes $0,5-3 \mathrm{~cm}$ compr., axilares, com (1)-3-7 capítulos. Capítulo masculino 4-5×3-6 mm; invólucro campanulado; filárias 3-4 séries, externas ovaladas, medianas elípticas, internas linearelípticas, margem escariosa. Flores masculinas 20-30; corola 3-3,5 mm compr., tubo 1,5-2 mm compr., fauce $0,5-0,8 \mathrm{~mm}$ compr., lacínias $0,5-$ $1 \mathrm{~mm}$ compr., pistilódio 3-4 mm compr., ápice bífido, ramos divergentes; papilho 3,5-4 mm 
compr. Capítulo feminino 3-3,5 × 2,5-3 mm, invólucro cilíndrico; filárias 3-4 séries, externas ovaladas, medianas elípticas, internas linearelípticas, margem escariosa. Flores femininas 30-40; corola 2-2,3 mm compr., 5-denticulada; estilete 2,5-3 mm compr. Cipselas maduras não examinadas; papilho 2,5-3,5 mm compr. Material examinado: BRASIL. RIO GRANDE DO SUL: Canguçu, 23.X.2008, R. Schmidt s.n. (ICN 157831). Encruzilhada do Sul, 15.XII.2007, M. Grings 321 (ICN). São Francisco de Paula, 18.XII.1950, fl., B. Rambo s.n. (PACA 48313),13.XI.1953, fl., B. Rambo s.n. (PACA 54521), 20.II.1953, fl., B. Rambo s.n. (PACA 52171).

Material adicional examinado: BRASIL. PARANÁ: Almirante Tamandaré, 22.VII.1970, fl., G. Hatschbach \& O. Guimarães 24520 (RB). Lapa, 5.XI.1964, fl., J. Mattos s.n. (SP 156264). Piraquara, 8.VII.1970, fl., N. Maguire 2406 (RB). Mallet, st., 7.XI.2005, G. Heiden 597 (RB). URUGUAI. Montevideo, 1836, fl., $F$. Sellow 3173 (síntipo B $\dagger$, foto em F!).

Baccharis vincifolia ocorre na Região Sul (PR, SC e RS) do Brasil e no Uruguai. No Rio Grande do Sul vegeta nos Campos de Cima da Serra e na Serra do Sudeste (Fig. 8). Trata-se de uma espécie rara, com ocorrência registrada nas transições entre formações campestres e florestais. A raridade de coletas indica a necessidade de inclusão na lista da flora ameaçada de extinção no estado, sendo necessários estudos adicionais visando definir o estado de conservação. Floresce entre agosto e dezembro. Popularmente é denominada cambará ou vassoura.

Espécie assemelhada a $B$. paranensis, podendo ser diferenciada conforme discutido previamente no presente estudo. $\mathrm{O}$ epíteto se refere à semelhança com folhas de vinca, planta da família Apocynaceae.

\section{Baccharis sp.}

Subarbustos 0,1-0,25 m alt., eretos, aparentemente glabros, indumento em diminutos tufos de tricomas clavados unisseriados e tricomas glandulares bisseriados. Caule e ramos eretos, ramos vegetativos e reprodutivos 3-alados, alas $0,2-2 \times 0,01-0,13 \mathrm{~mm}$, aplanadas nos ramos vegetativos e reprodutivos. Folhas escamiformes, sésseis, $0,1-0,7 \times 0,1-0,7 \mathrm{~mm}$, triangulares. Ramos espiciformes 1-4 cm compr., capítulos solitários ao longo dos ramos. Capítulo masculino $5,5-7 \times 2-4 \mathrm{~mm}$; invólucro campanulado; filárias 4-5 séries, externas oblongas, medianas oblongas, internas linear-oblongas, ápice denticulado, margem denticulada, escariosa. Flores masculinas 15-25; corola 4-5 mm compr., tubo 2-2.5 mm compr., fauce $0,5-0,8 \mathrm{~mm}$ compr., lacínias $1,5-$ 2 mm compr.; pistilódio 5-6,5 mm compr., ápice bífido, ramos coniventes; papilho $5-5,5 \mathrm{~mm}$ compr. Capítulo feminino 7,5-10,1×3-4,3 mm; invólucro cilíndrico; filárias 5-6 séries, externas ovaladas, medianas elípticas a lineares, internas lineares, margem estreitamente escariosa, inteira. Flores femininas 10-15; corola 5,5$6 \mathrm{~mm}$ compr., curto-ligulada, 5-denticulada; estilete 7-7,3 mm compr. Cipselas maduras não examinadas; papilho 7,5-8 mm compr. Material examinado: BRASIL. RIO GRANDEDO SUL: Mostardas, Lagoa do Peixe, 21.II.1970, fl., E. Viana et al. s.n. (ICN 7531). Rio Grande, Ilha dos Marinheiros, 29.II.1880, fl., Schwacke 283 (R 154293); 25.V.2009, fl., G. Heiden et al. 1053, 1054 (HECT, ICN, JE, RB). São José do Norte, I.1992, fl., P. Tagliani 77 (HURG); 10.XI.2008, G.H. Silveira \& P.C. Crespan s.n. (ICN 157830). Tavares, Lagoa do Peixe, 15.XII.1986, fl., E. Danilevicz 38 (HAS). Tramandaí, 20.VIII.2005, B. Irgang s.n. (ICN 157829).

Baccharis sp. ocorre na Região Sul do Brasil, sendo endêmica do estado do Rio Grande do Sul (Fig. 2). Trata-se de uma espécie rara com ocorrência registrada em dunas consolidadas da região fisiográfica Litoral. Os locais onde existem registros de coleta sofrem pressão antrópica devido ao plantio de espécies exóticas como a Casuarina L., utilizada na fixação de dunas, e cultivos extensivos silviculturais, como Pinus L., além de especulação imobiliária com expansão da área urbana e remoção das dunas. A distribuição geográfica restrita e a raridade de coletas indicam a necessidade de estudos para verificar a posição sistemática e a necessidade de inclusão na lista da flora ameaçada de extinção do Rio Grande do Sul. Fértil entre janeiro e maio.

Heiden (2005) ao examinar Tagliani 77 considerou o espécime como pertencente a $B$. 
triangularis Hauman, considerando uma possível nova ocorrência para o Brasil a ser confirmada mediante a análise de material adicional. Oliveira et al. (2006) citaram novamente a ocorrência de B. triangularis para o Brasil, entretanto, sem relacionarem material examinado. A revisão do exemplar estaminado citado por Heiden (2005) e o exame de coletas adicionais permitiram reconhecer características diferenciais entre esses espécimes e B. triangularis. Esse táxon se assemelha à $B$. triangularis devido ao hábito e habitat semelhantes e às alas estreitas do caule. Entretanto, Baccharis sp. pode ser diferenciada principalmente pela ausência de um pseudoinvólucro de folhas reduzidas a escamas bractiformes cuneadas, agrupadas ao redor de capítulos solitários, que ocorrem isoladamente no ápice dos ramos férteis de $B$. triangularis.

Baccharis triangularis é considerada endêmica da região de Rio Negro, ao sul de Buenos Aires, Argentina, enquanto Baccharis sp. é um táxon autônomo e endêmico do litoral sulriograndense. Adisposição dos capítulos nos ramos, o invólucro dos capítulos e a corola das flores femininas indicam que essa espécie é relacionada com B. riograndensis, distinguindo-se pelo porte menor, alas vegetativas estreitas, capítulos masculinos maiores e capítulos femininos com menos flores.

Material adicional examinado de Baccharis triangularis Hauman, Anal. Mus. Nac. Hist. Nat. Buenos Aires, 24: 428. 1913. ARGENTINA. Buenos Aires, II.1898, C. Spegazzini s.n. (LP 11490). [holótipo de Baccharis trimera var. viscosissima, sinônimo de $B$. triangularis].

\section{Considerações Finais}

O estudo das coleções permitiu confirmar a ocorrência de 22 espécies de Baccharis sect. Caulopterae no Rio Grande do Sul. Baccharis palustris ocorre no estado de Santa Catarina em regiões fronteiriças com o Rio Grande do Sul, em condições ambientais semelhantes às encontradas no nordeste do estado, mas até o momento não foi coletada em território sul-riograndense.
Coletas em regiões limítrofes com o Uruguai e a Argentina nos extremos sul e oeste do estado devem ser realizadas, visando refinar o conhecimento sobre a distribuição geográfica das espécies com limite setentrional de distribuição no Rio Grande do Sul, assim como nas regiões de altitude do nordeste, visando melhor reconhecer os limites austrais de distribuição geográfica das espécies características das regiões de altitude do Sul e Sudeste do Brasil. A posição sistemática de Baccharis sp. deve ser esclarecida em futuros estudos.

\section{Agradecimentos}

Os autores agradecem aos funcionários dos herbários consultados o acesso às coleções e/ou empréstimo de material; aos pesquisadores Ângelo Alberto Schneider (Universidade Federal do Rio Grande do Sul), Aristônio Magalhães Teles (Universidade Federal de Goiás), Daniel Alejandro Giuliano (Museo de La Plata), David Byrne (Texas A\&M University), D.J. Nicholas Hind (Royal Botanic Gardens Kew), Diego Gutiérrez (Museo de La Plata), Guy L. Nesom (Botanical Research Institute of Texas), Jochen Müller (Herbarium Haussknecht, Friedrich-Schiller-Universität) e Rafael Augusto Xavier Borges (Instituto de Pesquisas Jardim Botânico do Rio de Janeiro), o intercâmbio de material científico, disponibilidade para discussão e/ou apoio prestado em diferentes etapas da elaboração desse trabalho; e aos pesquisadores Marccus Alves, Jimi Naoki Nakajima e Nicholas Hind a revisão técnica e sugestões valiosas para o aperfeiçoamento desse artigo.

\section{REFERÊNCIAS BIBLIOGRÁFICAS}

Ariza Espinar, L. 1973. Las especies de Baccharis (Compositae) de Argentina Central. Boletim de la Academia Nacional de Ciencias de Cordoba 50(1-4): 1-305.

Baker, J.G. 1882. Compositae. III. Asteroideae, Inuloideae. In: Martius, C. F. P. von; Eichler, A. W. \& Urban, I. Flora brasiliensis. München, Wien, Leipzig, 6(3): 1-442. 
Barroso, G.M. 1976. Compositae, subtribo Baccharidinae Hoffman. Estudo das espécies ocorrentes no Brasil. Rodriguésia 28: 3-273.

Barroso, G.M. \& Bueno, O. 2002. Compostas - 5. Subtribo: Baccharidinae. In: Reitz, R. (ed.). Flora Ilustrada Catarinense. Herbário Barbosa Rodrigues, Itajaí, Fasc. COMP. Pp. 765-1065.

Borges, R.A.X \& Forzza, R.C. 2008. A tribo Astereae (Asteraceae) no Parque Estadual do Ibitipoca, Minas Gerais, Brasil. Boletim de Botânica da Universidade de São Paulo 26 (2): 131-154.

Bowden, W.M. 1945. A list of chromosome numbers in higher plants. I. Acanthaceae to Myrtaceae. American Journal of Botany 32:81-92.

Cabrera, A. L. 1963. Flora de la Provincia de Buenos Aires. VI: Compuestas. Instituto Nacional de Tecnología Agropecuaria, Buenos Aires. 433p.

Cabrera, A.L. 1971. Compositae. In: Correa, M.N. (ed.). Flora patagonica. Buenos Aires, Instituto Nacional de Tecnología Agropecuaria. Pp. 5-96.

Cabrera, A.L. 1974. Compositae, compuestas. In: Burkart, A. (ed.). Flora ilustrada de Entre Ríos (Argentina). Vol 6. Instituto Nacional de Tecnología Agropecuaria, Buenos Aires. Pp. 106-538.

Cabrera, A.L.1978. Flora de la Provincia de Jujuy. 10: Compositae. Buenos Aires, Instituto Nacional de Tecnología Agropecuaria.

Coleman, J.R. 1968. Chromosome numbers in some Brazilian Compositae. Rhodora 70: 228-240.

Corrêa, M.P. 1984. Dicionário das plantas úteis do Brasil e das exóticas cultivadas VI: CAR-E. Imprensa Nacional, Rio de Janeiro. 173p.

De Candolle, A. P. 1836. Prodromus systematis naturalis regni vegetabilis 5 - Sistens Calycereas et Compositarum tribus priores. Treuttel \& Würtz, Paris. Pp. 398-429.

Diesel, S. 1987. Contribuição ao estudo taxonômico do gênero Baccharis L. (grupo Trimera) no Rio Grande do Sul. Pesquisas, Botânica 38: 91-126.

Dusén, P.K.O. 1910. Gefäsplanzen aus Paraná. Arkiv för Botanik, 9(15): 23-30. 1910.

Fielding, R.R. 2001. Baccharis: a genus of the Asteraceae new to Canada. Proceedings of the Nova Scotian Institute of Science 41(4): 214-215.

Giuliano, D.A. 2000. Asteraceae, parte 15. Tribu III. Astereae, parte A. Subtribu c. Baccharidinae. In: Flora Fanerogámica Argentina 66:1-74. Córdoba, PROFLORA (CONICET).
Giuliano, D.A. 2001. Classificación infragenérica de las espécies Argentinas de Baccharis (Asteraceae, Astereae). Darwiniana 39(1-2): 131-154.

Heering, W.C. 1911. Baccharis L. In: Usteri, A. Flora der Umgebung der Stadt São Paulo. Jena. Pp. 258-251.

Heering, W.C. 1916. Systematische und pflanzengeographische Studien über die Baccharis-Arten des auâertropischen Südamerikas. Jahrbuch der Hamburgischen Wissenschaftlichen Anstalten 3: 63-173.

Heiden, G. 2005. O gênero Baccharis L. secção Caulopterae DC. (Asteraceae) no Rio Grande do Sul. Monografia de Graduação. Universidade Federal de Pelotas, Pelotas. 238p. Disponível em: http://www.ufpel.tche.br/prg/sisbi/bibct/ acervo/biologia/2005/tcc_gustavo_ heiden.pdf. Acesso em julho 2006.

Heiden, G.; Macias, L.; Bobrowski, V.L. \& Iganci, J.R.V.I. 2006a. Comercialização de carqueja por ervateiros da zona central de Pelotas, Rio Grande do Sul. Revista de Biologia e Ciências da Terra 6(2): 50-57.

Heiden, G.; Iganci, J.R.V.I.; Stein, V. \& Bobrowski, V.L. 2006b. Número cromossômico de Baccharis riograndensis Malag. \& J. E. Vidal (Asteraceae). Pesquisas, Botânica 57: 121-136.

Heiden, G.; Iganci, J.R.V.; Bobrowski, V.L. \& Macias, L. 2007. Biogeografía de Baccharis sect. Caulopterae (Asteraceae) no Rio Grande do Sul, Brasil. Rodriguésia 58(4): 787-796.

Heiden, G.; Iganci, J.R.V. I. \& Macias, L. 2008. Two new species of Baccharis L. (Asteraceae, Astereae) from Southern Brazil. Novon 18(2): 178-182.

Heiden, G.\& Schneider, A.A. 2008. Lectotypification and notes on Baccharis riograndensis (Asteraceae, Astereae). Journal of the Botanical Research Institute of Texas 2(1): 291-295.

Hind, D.J.N. 1993. Notes on the Compositae of Bahia, Brazil: I. Kew Bulletin 48: 245-277.

Holmgren, P.K. \& Holmgren, N.H. 1998. [continuously updated]. Index Herbariorum: a global directory of public herbaria and associated staff. New York Botanical Garden's Virtual Herbarium. <http://sweetgum.nybg.org/ih/>. Acesso em 10 julho 2009.

Jeffrey, C. 2006. Compositae. Introduction with keys to tribes. In: Kadereit, J.W. \& Jeffrey, C. (eds.). 
The families and genera of vascular plants (K. Kubitzki series editor), Vol. VIII. Flowering plants: Eudicots: Asterales. Springer, Berlin. Pp. 61-77.

Lessing, C.F. 1831a. Synanthereae. [De plantis in expeditione romanzzofiana.]. Linnaea 6: 83-170.

Lessing, C.F. 1831b. Synanthereae: Molinae-Alatae. Linnaea 6: 83-170.

Malagarriga Heras, R.P. 1949a. [Irmão Teodoro Luis]. De "Re-Botânica". Boletim Informativo do Instituto Geobiológico La Salle 2: 17. 1949b

Malagarriga Heras, R.P. 1949b. [Irmão Teodoro Luis]. Exsiccata Baccharidinarum. Boletim Informativo do Instituto Geobiológico La Salle 1: 11-14.

Malagarriga Heras, R.P.1952. [Irmão Teodoro Luis]. Index Baccharidinarum (Compositae). Contribuições do Instituto Geobiológico La Salle 2: 1-55.

Malagarriga Heras, R.P.1954. [Irmão Teodoro Luis]. Exsiccatae Baccharidinarum. I. Plantae WilsonHoehneana. Contribuições do Instituto Geobiológico La Salle 3: 1-20.

Malagarriga Heras, R. P. 1957. [Irmão Teodoro Luis]. Para o estudo da flora sul-riograndense qual o valor da "Flora brasiliensis" de Martius? Contribuições do Instituto Geobiológico La Salle 8: 1-61.

Malagarriga Heras, R. P.1958. [Irmão Teodoro Luis]. Novum Index Baccharidinarum. Contribuições do Instituto Geobiológico La Salle 9: 1-35.

Malagarriga Heras, R.P. 1977. Nomenclator baccharidinarum omnium. Memórias da Sociedade de Ciências Naturais La Salle 37: 129-224.

Malme, G.O.A.N. 1931. Die Compositen der zweiten Regnellschen Reise I. Rio Grande do Sul. Arkiv för Botanik 24(8): 50-52.

Müller, J. 2006a. Systematics of Baccharis (Compositae-Astereae) in Bolivia, including an overview of the genus. Systematic Botany Monographs 76:1-341.
Müller, J.2006b. A new subspecies of Baccharis L. (Compositae-Astereae) with winged stems from Argentina. Haussknechtia 11: 143-147.

Nesom, G. \& Robinson, H. 2006. XV. Tribe Astereae Cass. In: Kadereit, J. W. \& Jeffrey, C. (eds.), The families and genera of vascular plants (K. Kubitzki series editor), Vol. VIII. Flowering plants: Eudicots: Asterales. Springer, Berlin. Pp. 284-342.

Oliveira, A.S.; Deble, L.P.; Schneider, A.A. \& Marchiori, J.N.C. 2006. Checklist do gênero Baccharis L. para o Brasil (AsteraceaeAstereae). Balduinia 9: 17-27.

Panero, J.L. \& Funk, V. A. 2008. The value of sampling anomalous taxa in phylogenetic studies: major clades of the Asteraceae revealed. Molecular phylogenetics and evolution 47: 757-782.

Rozenblum, E.; Waisman, C.E. \& Hunziker, J.H. 1985. Estudios cariológicos en Compositae. II. Darwiniana 26: 15-25.

Schneider, A.A. \& Boldrini, I.I. 2008. Two new species of Baccharis sect. Caulopterae (Asteraceae: Astereae) from Southern Brazil. Journal of the Botanical Research Institute of Texas 2(1): 45-51.

Schneider, A.A.; Heiden, G. \& Boldrini, I.I. 2009. Notas nomenclaturais em Baccharis sect. Caulopterae DC. (Asteraceae). Revista Brasileira de Biociências 7(2): 225-228.

Simões, C.M.O.; Mentz, L.A.; Schenkel, E.P.; Irgang, B.E., \& Stehmann, J.R. 1995. Plantas da medicina popular no Rio Grande do Sul. $4^{\mathrm{a}}$ ed. UFRGS, Porto Alegre. 173p.

Sprengel, K. 1826. Systema vegetabilium, $16^{\mathrm{a}}$ ed., vol. 3. Göttingen, Dieterich.

Stumpf, E.R.T.; Heiden, G.; Barbieri, R.L.; Fischer, S.Z. \& Neitzke, R.S. 2008. Espécies nativas do Bioma Pampa para uso como folhagem de corte. Revista Brasileira de Horticultura Ornamental 14(2): 123-133.

Soria, N. 1993. Las especies aladas de Baccharis utilizadas como medicinales en Paraguay. Rojasiana 1:3-12. 